\author{
UNIVERSIDADE DE SÃO PAULO \\ FACULDADE DE MEDICINA DE RIBEIRÃO PRETO \\ PROGRAMA DE PÓS-GRADUAÇÃO MESTRADO PROFISSIONAL EM \\ HEMOTERAPIA E BIOTECNOLOGIA
}

\title{
MANUAL TÉCNICO PARA PRODUÇÃO E USO DO CONTROLE DE QUALIDADE INTERNO EM TESTES DE AMPLIFICAÇÃO DE ÁCIDOS NUCLEICOS (CQI-NAT)
}

Giselle Bissaro Barban

Ribeirão Preto

2015 


\title{
MANUAL TÉCNICO PARA PRODUÇÃO E USO DO CONTROLE DE QUALIDADE INTERNO EM TESTES DE AMPLIFICAÇÃO DE ÁCIDOS NUCLEICOS (CQI-NAT)
}

\begin{abstract}
Manual técnico apresentado à Faculdade de Medicina de Ribeirão Preto da Universidade de São Paulo para a obtenção do título de Mestre em Ciências. Área de concentração: Hemoterapia e Medicina Transfusional.

Orientadora: Simone Kashima Haddad

"Versão corrigida. A versão original encontra-se disponível tanto na biblioteca da unidade que aloja o programa quanto na biblioteca digital de teses e dissertações da USP (BDTD)".
\end{abstract}

Ribeirão Preto 
Autorizo a reprodução e divulgação total ou parcial deste trabalho, por qualquer meio convencional ou eletrônico, para fins de estudo e pesquisa, desde que citada a fonte.

FICHA CATALOGRÁFICA

Barban, Giselle B.

Manual técnico para produção e uso do Controle de Qualidade Interno em Testes de Amplificação de Ácidos Nucleicos (CQI-NAT) / Giselle B. Barban Evangelista; orientadora, Simone Kashima Haddad - Ribeirão Preto, SP, 2015.

$110 p$.

Universidade de São Paulo, Faculdade de Medicina de Ribeirão Preto, programa de pós-graduação, mestrado profissional em hemoterapia e biotecnologia, Ribeirão Preto, SP, 2015.

1. Controle de Qualidade Interno. 2. Testes do Ácido Nucleico. 3. Triagem laboratorial. 4. Doadores de sangue. I. Barban, Giselle B. II. Universidade de São Paulo, Faculdade de Medicina de Ribeirão Preto. III. Manual prático para produção e uso do Controle de Qualidade Interno em Testes de Amplificação de Ácidos Nucleicos (CQI-NAT). 
Barban, G. B. Manual técnico para produção e uso do controle de qualidade interno em Testes de Amplificação de Ácidos Nucleicos (CQI-NAT). Apresentado à Faculdade de Medicina de Ribeirão Preto da Universidade de São Paulo para obtenção do título de Mestre em Ciências, área de concentração: Hemoterapia e Medicina Transfusional.

Aprovado em:

Banca Examinadora:

$\operatorname{Prof}(\mathrm{a}) . \operatorname{Dr}(\mathrm{a})$ : Instituição:

Julgamento: Assinatura:

Prof (a). Dr (a): Instituição:

Julgamento: Assinatura:

Prof (a). Dr (a): Instituição:

Julgamento: Assinatura: 


\section{AGRADECIMENTOS}

Primeiramente agradeço à Deus, por sempre iluminar meus caminhos.

Aos meus pais Edson e Agmar pela união, amor e caráter, ao Gabriel, meu querido irmão, pela parceria e significado em minha vida e a minha avó Agmar por seu exemplo de força e perseverança.

Ao meu amado marido Fábio pelo apoio, companheirismo, confiança e pelo grande amor.

Aos meus padrinhos Marcos e Maria Lúcia e minha tia Leila pelo carinho que sempre tiveram comigo. A Camila pelo amor de uma irmã.

Às amigas, em especial Caiti, Larissa e Rebeca por estarem presentes em todos os momentos.

Ao Hemocentro de Ribeirão Preto por ser um serviço de hemoterapia de referência nacional e internacional, onde tive além da oportunidade de aprimoramento profissional na área de hemoterapia e hematologia a possibilidade de fazer grandes amigos.

À Dra. Eugênia, Dr. Dimas, Rochele, Daniela, Priscila, Natália, Maria Ângela, Juliana, Maxwell e Vanderléia e às equipes dos laboratórios NAT, Controle e Gestão da qualidade e de Biologia Molecular do Hemocentro de Ribeirão Preto por todo apoio durante a elaboração desse trabalho.

À Simone, minha querida orientadora, agradeço pela amizade, por estar sempre presente, pelo aprendizado que me proporcionou durante essa etapa tão importante e única em minha vida. Obrigada por participar e também acreditar que seria possível!

À Coordenação-Geral de Sangue e Hemoderivados do Ministério da Saúde por essa oportunidade de cursar o mestrado profissional em hemoterapia, em especial ao Dr. Guilherme Genovez pela confiança, às meninas da área de Assessoramento Técnico em Hemoterapia pela paciência e compreensão e ao Dr. Marcelo Addas e Dra. Patrícia Alvarez pelas sugestões.

Ao Grupo de Assessoramento Técnico do NAT pela dedicação e trabalho em prol da hemoterapia brasileira. À Andrea Petry pelo carinho e pelo "pequeno livro azul" que auxiliou na composição desse manual técnico.

Aos colegas do curso de mestrado profissional por também acreditarem em seus sonhos, em especial Bárbara e Helder, meus parceiros nessa jornada, ao professor Dr. Edson Martinez e a todos os brilhantes professores pelos ensinamentos e dedicação. 
Dedico esse manual técnico para todos os profissionais que trabalham com a rotina NAT nos serviços de hemoterapia do país. 
"No que diz respeito ao empenho, ao compromisso, ao esforço e a dedicação, não existe meio termo. Ou você faz uma coisa bem feita ou não faz." 


\section{RESUMO}

Evangelista, G. B. B. Manual técnico para produção e uso do controle de qualidade interno em Testes de Amplificação de Ácidos Nucleicos (CQI-NAT). 2015. 110f. Dissertação (Mestrado). Faculdade de Medicina Ribeirão Preto Universidade de São Paulo, Ribeirão Preto, 2015.

A obrigatoriedade de realização do Teste de Ácidos Nucleicos (NAT) na triagem laboratorial dos candidatos à doação de sangue, permite o aumento da segurança transfusional, uma vez que o teste detecta precocemente o material genético dos vírus transmissíveis por transfusão. Com a introdução do NAT na prática diária dos serviços de hemoterapia brasileiros, foi também preconizada a utilização do controle interno de qualidade (CQI) como um parâmetro adicional para liberação de resultados com maior confiabilidade. Este manual técnico tem como objetivo subsidiar os serviços de hemoterapia na implantação e análise do CQI-NAT, auxiliando nas ações de melhoria contínua dos processos. Para tanto, foram implantados e validados no laboratório NAT, do hemocentro de Ribeirão Preto, nove procedimentos operacionais que contemplam todo o fluxo de produção das amostras para CQI-NAT, desde sua validação com testes de homogeneidade e estabilidade, definição dos limites dos gráficos de controle e utilização na rotina laboratorial, possibilitando a identificação de erros sistemáticos ou aleatórios que possam prejudicar os resultados da rotina. 


\section{ABSTRACT}

Evangelista, G. B. B. Technical manual for production and use of internal quality control in Nucleic Acid Amplification Testing (NAT-CQI). 2015. 110f. Dissertação (Mestrado). Faculdade de Medicina Ribeirão Preto - Universidade de São Paulo, Ribeirão Preto, 2015.

The mandatory nucleic acid test in candidates for blood donors increased the safety transfusion, since because the test detect first the genetic material of the virus transmitted by transfusion. With the introduction of NAT in daily practice of blood banks, the use of internal quality control also recommended as one additional parameter to release results with more confiability. This technical manual can guide the blood Banks in implantation of NAT-CQI to uniformize their production process and analysis and contributing with the continuous process improvement. For both in NAT laboratory of Ribeirão Preto, were implemented and validated nine operating procedures with the flow that allowed the production of NAT-CQI samples, from validation with homogeneity and stability tests, definitions of the limits for the control graphics to utilization in daily practice, enabling the identification of systematic or random errors that can damaged the tests result. 


\section{LISTA DE ABREVIATURAS E SIGLAS}

$\mu \mathrm{L}$ - Microlitro

ABNT - Associação Brasileira de Normas Técnicas

ANVISA - Agência Nacional de Vigilância Sanitária

CONITEC - Comissão Nacional de Incorporação de Tecnologias no Sistema Único de Saúde

CQE - Controle de qualidade externo

CQI - Controle de qualidade interno

CRF - Formas circulantes recombinantes (do inglês, Circulating Recombinant Forms)

Ct - Cycle Threshold

CV - Coeficiente de variação

DNA - Ácido desoxirribonucleico

ELISA - Ensaio imunoenzimático (do inglês, enzyme-linked immuno sorbent assay)

HBcAg - Antígeno do core do vírus da Hepatite B

HBsAg - Antígeno de superfície do vírus da Hepatite B

HBV - Vírus da hepatite tipo B (do inglês, Hepatitis $B$ virus)

HCV - Vírus da hepatite tipo C (do inglês, Hepatitis $C$ vírus)

HIV - Vírus da imunodeficiência humana (do inglês, Human immunodeficiency virus)

HTLV - Vírus T-linfotrópico humano (do inglês, Human T-cell lymphotropic virus)

ISO - Organização Internacional de Normalização (do inglês, International Organization for Standardization)

$\mathrm{mL}$ - Mililitro

NAT - Teste do ácido nucleico (do inglês, nucleic acid test)

NBR - Norma brasileira

NOTIVISA/ANVISA/MS - Sistema de Notificação em Vigilância Sanitária/Agência Nacional de Vigilância Sanitária/Ministério da Saúde

${ }^{\circ} \mathrm{C}$ - Graus Celsius

ORF - Origens de replicação (do inglês, open reading frame) 
PDCA - Planejar, fazer, conferir, agir (do inglês, Plan, Do, Check, Act)

PFC - Plasma fresco congelado

PHN - Plasma humano negativo

POP - Procedimento operacional padrão

RDC - Resolução da Diretoria Colegiada

RNA - Ácido ribonucleico

SIDA - Síndrome da imunodeficiência adquirida

SINAN/SVS/MS - Sistema de Informação de Agravos de Notificação/Secretaria de Vigilância em Saúde/Ministério da Saúde

TMA - Amplificação mediada por transcrição (do inglês, Transcription-Mediated Amplification) 


\section{ÍNDICE}

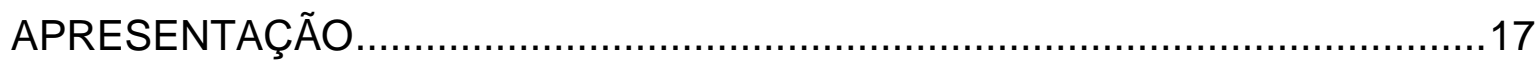

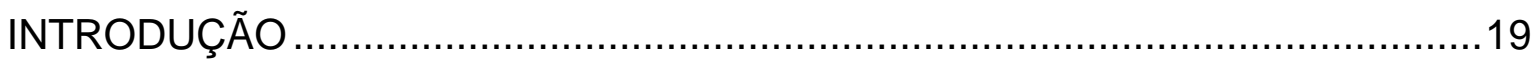

1. Teste do Ácido Nucleico (NAT) para triagem laboratorial de doadores de

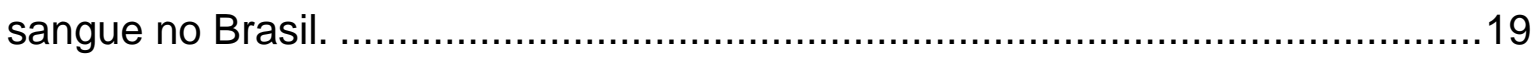

2. Marco regulatório da implantação, disponibilização e obrigatoriedade do NAT.

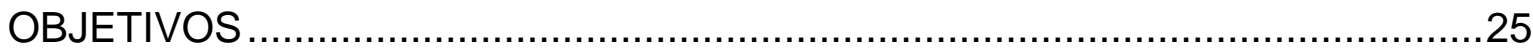

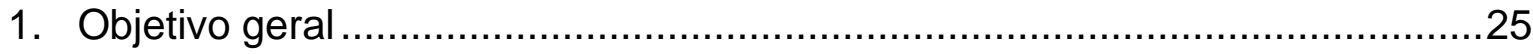

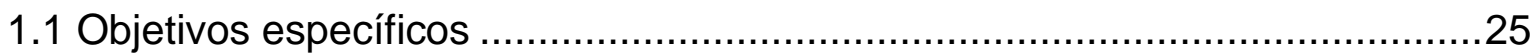

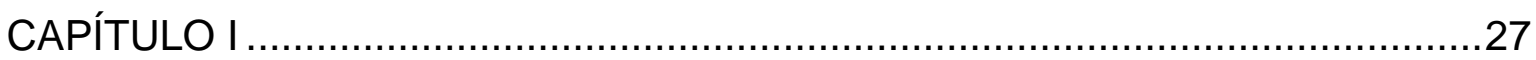

Principais vírus transmissíveis por transfusão com triagem disponível pelo NAT.27

1.1 Vírus da Imunodeficiência Humana (HIV) .................................................27

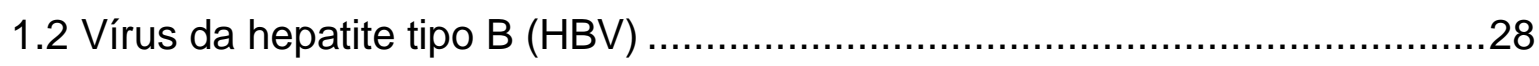

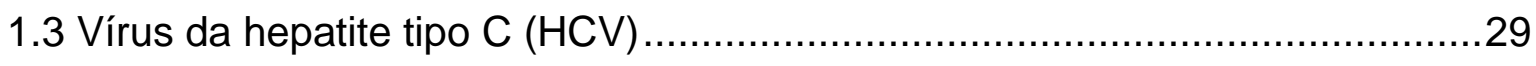

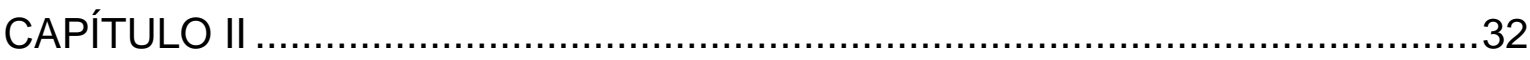

1. A qualidade e o início do sistema de gestão aplicado aos serviços de

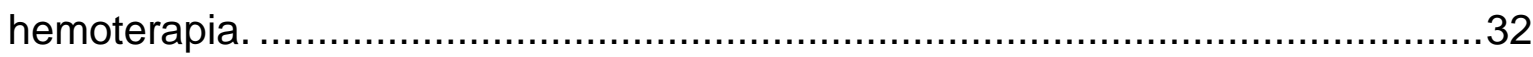

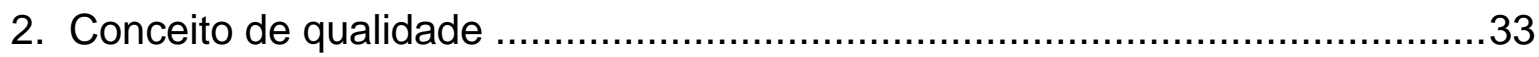

3. Os resultados do controle de qualidade como ferramenta de avaliação ...........34

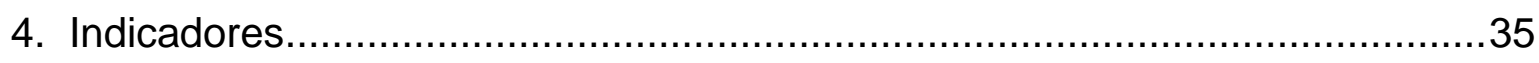

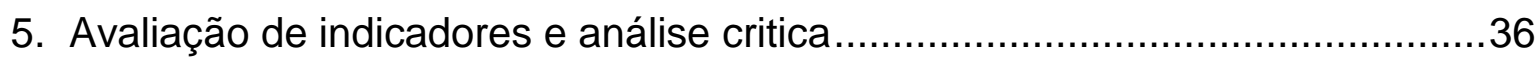

6. Melhoria contínua da qualidade .............................................................36

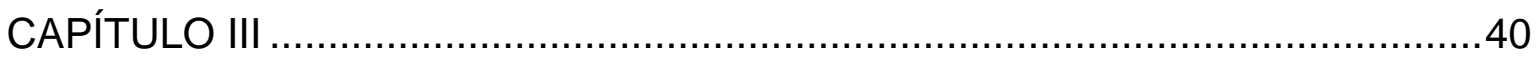

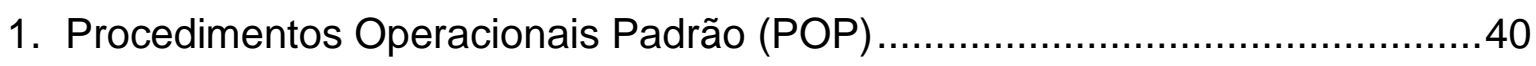


1.1 Seleção das bolsas para produção do CQI-NAT

1.2 Aliquotagem das bolsas positivas selecionadas

1.3 Curva de diluição e seleção da amostra ideal para produção do CQI-NAT ...46

1.4 Diluição e preparo do CQI-NAT .51

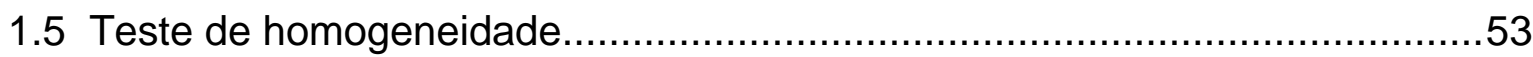

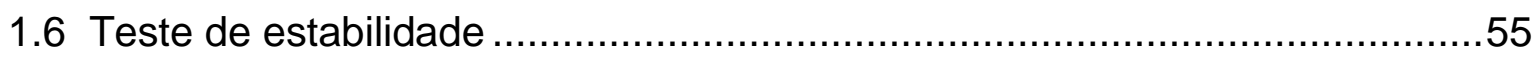

1.7 Produção do Plasma Humano Negativo (PHN) …………………..............57

1.8 Análise estatística complementar para definição dos limites de aceitação do CQI-NAT na rotina

1.9 Processamento na rotina e acompanhamento ...............................................68

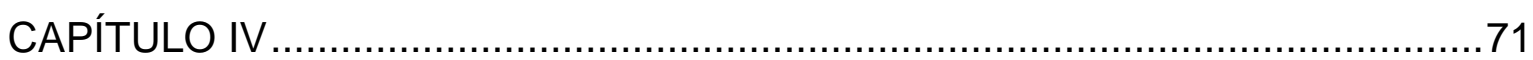

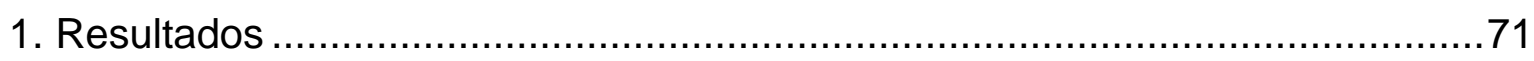

1.1 Caracterização das bolsas de plasma positivas para HIV e HCV ...................71

1.2 Teste de Homogeneidade e estabilidade ...................................................77

1.3 Produção do Plasma Humano Negativo …………………………….........

1.4 Definição dos limites do gráfico controle para acompanhamento do CQI-NAT

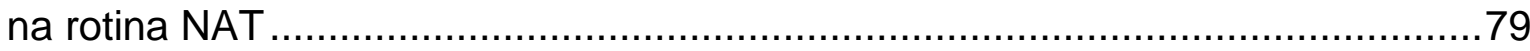

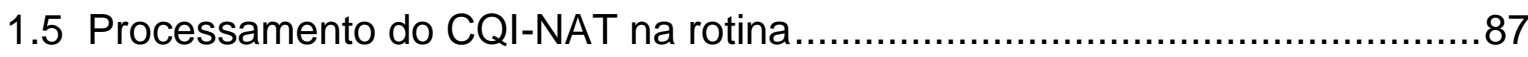

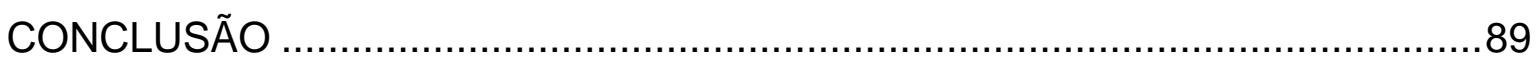

Apêndice I - Modelo de planilha de registro dos resultados da triagem laboratorial sorológica e molecular das bolsas selecionadas para produção do CQI-NAT e

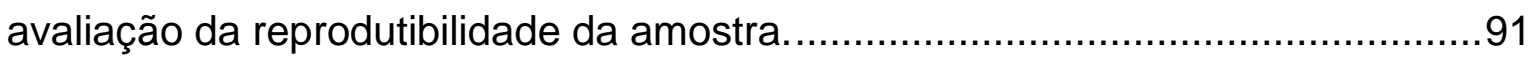

Apêndice II - Modelo de etiqueta de identificação para bolsa segregada com

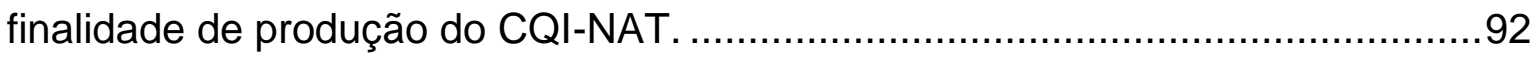

Apêndice III - Modelo de planilha para registro da temperatura de descongelamento das bolsas de PFC para produção do CQI-NAT.......................93

Apêndice IV - Modelo de planilha para registro de uso da luz ultravioleta............94

Apêndice $\mathrm{V}$ - Modelo de etiqueta para identificação do tubo de aliquotagem da

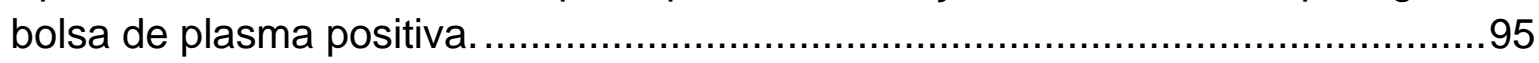


Apêndice VI - Modelo de planilha para registro da curva de diluição da amostra positiva.

Apêndice VII - Modelo de registro da reprodutibilidade da diluição ideal da amostra positiva para CQI-NAT.

Apêndice VIII - Modelo de etiqueta para identificação do CQI-NAT.

Apêndice IX - Exemplo para seleção de amostras aleatórias utilizando a função do programa Excel.

Apêndice X - Modelo de registro dos dados do teste de homogeneidade do CQINAT.

Apêndice XI - Modelo de registro dos dados do teste de estabilidade. 101

Apêndice XII - Modelo de planilha para registro da produção de PHN. 102 Apêndice XIII - Modelo de etiqueta para identificação dos tubos do lote de PHN. 103 


\title{
CRÉDITOS
}

\author{
Elaboração \\ Giselle B. Barban \\ Orientação \\ Simone Kashima Haddad
}

Colaboração

Dimas Tadeu Covas

Edson Zangiacomi Martinez

Equipe do laboratório NAT do Hemocentro de Ribeirão Preto

Eugênia Amorim Ubiali

Maria Angela P. Ottoboni

Maxwell Marques Santos

Priscila Ricardi Rocha

Rochele Azevedo França

Vanderléia Bárbaro Valente 


\section{APRESENTAÇÃO}

Atualmente, a gestão da qualidade é prática intrínseca no âmbito dos serviços de hemoterapia para o monitoramento dos processos da rotina, com o objetivo de oferecer à população um produto final dentro dos padrões de conformidade, atendendo aos critérios de segurança e qualidade.

Considerando a busca pela segurança transfusional como um ponto importante para o padrão de excelência dos hemocomponentes e hemoderivados, o Ministério da Saúde tornou obrigatória, em 2013, a realização do Teste do Ácido Nucleico (NAT), que em conjunto com os testes de triagem sorológica, visam diminuir a transmissão de doenças infecciosas por transfusão.

Dentro desse contexto, a utilização de controle de qualidade interno, para o monitoramento da reprodutibilidade das rotinas laboratoriais, inclusive do NAT, é necessária e obrigatória pela legislação brasileira.

Assim, este Manual técnico para produção e uso do controle de qualidade interno em Testes de Amplificação de Ácidos Nucleicos (CQI-NAT) tem por objetivo propor protocolos padronizados para produção de controle de qualidade interno para o referido teste, além de auxiliar e orientar a Hemorrede quanto à utilização do CQINAT como importante ferramenta do sistema de gestão da qualidade para acompanhamento dos processos e proposição de ações de melhoria contínua. 
Teste do Ácido Nucleico (NAT) para triagem laboratorial de doadores de sangue no Brasil

Marco regulatório da implantação, disponibilização e obrigatoriedade do NAT 


\section{INTRODUÇÃO}

\section{Teste do Ácido Nucleico (NAT) para triagem laboratorial de doadores de sangue no Brasil.}

O intenso aperfeiçoamento dos conjuntos diagnósticos desde os anos 80, após o advento da Síndrome da Imunodeficiência Adquirida (SIDA), proporcionou o desenvolvimento de uma das áreas de suma importância nos serviços de hemoterapia, a triagem laboratorial. Também, as ações de captação e de triagem clínica dos candidatos à doação, ao longo dos anos, permitiram a seleção de doadores voluntários e fidelizados e auxiliaram na diminuição da transmissão de doenças infecciosas por transfusão (Dodd, Notari e Stramer, 2002; Stramer et al., 2004).

Ainda assim, é possível ocorrer transmissão de doenças infecciosas por transfusão, uma vez que a existência do risco residual transfusional pode ser decorrente tanto da sensibilidade dos testes utilizados na triagem laboratorial, em que não é possível identificar doações que estejam no início do período de viremia infecciosa, quanto de erros técnicos e humanos que ocorrem de forma sistemática ou aleatória durante a realização das rotinas de testes (Busch et al., 2005). Igualmente, a busca de testes por pessoas que tiveram uma recente exposição ao risco e a cinética de replicação viral durante o período compreendido entre a fase inicial da infecção e a caracterização da resposta imunológica do organismo, janela imunológica, podem contribuir para o aumento do risco residual transfusional (Busch et al., 2005; Kleinman, Lelie e Busch, 2009). Dessa forma, o constante aprimoramento das ações de captação de doadores, bem como implantação de conjuntos diagnósticos com maior sensibilidade e especificidade na detecção de agentes infecciosos é essencial na busca da qualidade e segurança transfusional.

No laboratório de sorologia, os testes imunoenzimáticos (do inglês, enzymelinked immuno sorbent assay, ELISA) de $3^{\text {a }}$ geração permitem a detecção de anticorpos ou antígenos presentes na amostra de plasma ou soro do doador. A sensibilidade desses testes na detecção dos patógenos após a infecção é cerca de 20 dias para o vírus da imunodeficiência humana (HIV), de 60 a 80 dias para o vírus 
da hepatite tipo $\mathrm{C}(\mathrm{HCV})$ e, de 56 a 59 dias para o vírus da hepatite tipo B (HBV) (Busch et al., 1995; Stramer et al., 2004; Beer et al., 2006; Kleinman, Lelie e Busch, 2009; Kosan et al., 2010). Nos testes sorológicos de 4ª geração, também utilizados pelos serviços de hemoterapia para triagem de HIV e HCV em doadores de sangue, há a detecção simultânea de anticorpos e antígenos em uma mesma reação. Este fator possibilita uma diminuição do intervalo de detecção para aproximadamente 14 dias para o HIV e 17 dias para o HCV, sendo que este último, quando comparado com testes imunoenzimáticos apenas para anticorpos, apresenta uma redução de 70\% no intervalo de detecção (Tuke et al., 2008; Daskalakis, 2011; Owen, 2012; Cornett e Kirn, 2013).

Entretanto, a maioria dos testes apresentam limitações metodológicas, no caso dos testes sorológicos, a detecção de antígenos e anticorpos depende previamente da formação de uma resposta imunológica do organismo, impossibilitando a identificação dos agentes virais no início de seu ciclo replicativo, aumentando, nesse período, a possibilidade de transmissão transfusional desses patógenos (Stramer et al., 2004; Kleinman, Lelie e Busch, 2009).

$\mathrm{Na}$ década de 1990, iniciou-se a implantação das técnicas de biologia molecular para pesquisa dos agentes infecciosos na triagem de doadores de sangue. A Alemanha foi o primeiro país a introduzir o NAT (1997) na triagem laboratorial dos serviços de hemoterapia (Cardoso, Koerner e Kubanek, 1998). E, devido à prevalência e longo período de janela imunológica, o HCV foi o primeiro vírus a ser pesquisado por tais técnicas (Cardoso, Koerner e Kubanek, 1998; Willkommen, Schmidt e Lower, 1999; Coste et al., 2005).

Com a utilização dos Testes de Amplificação de Ácidos Nucleicos (NAT) é possível a detecção direta dos ácidos nucleicos de vírus na amostra do doador, antes mesmo da produção de anticorpos pelo organismo. Dessa forma, há diminuição do período de janela imunológica para 11, 12 e 20 dias após a infecção para HIV, HCV e HBV, respectivamente (Roth, Weber e Seifried, 1999; Kleinman, Lelie e Busch, 2009; Kosan et al., 2010). Entretanto, há casos descritos de pessoas que com o NAT detectável, especialmente para HCV e que não apresentam soroconversão, ou esta se dá tardiamente (Stramer, 2004). 


\section{Marco regulatório da implantação, disponibilização e obrigatoriedade do NAT.}

A implantação do NAT nos serviços de hemoterapia nacionais foi introduzida inicialmente, em 2002, pela publicação das Portarias ํo 262/2002 e ํำ 1.407/2002, porém, uma vez identificada inexistência de registro dos conjuntos diagnósticos para realização do teste na triagem laboratorial de doadores, ambas foram revogadas pela Portaria no 79/2003. Essa, também não pôde ser praticada devido ao alto custo de implantação da metodologia à época (BRASIL, 2002b; a; 2003; Jackson et al., 2003; Petry, 2013).

Em 2004, foi publicada a Portaria o 112/2004, que possibilitou a implantação e disponibilização do teste de forma gradativa, além de determinar os serviços responsáveis pela sua realização, de maneira centralizada, para a Hemorrede Nacional. Desde então, o Ministério da Saúde promoveu o desenvolvimento e produção de um Kit nacional, bem como o registro e aprovação daqueles já disponíveis pelas empresas comerciais (BRASIL, 2004; Petry, 2013).

Assim, desde 2004, a evolução dos estudos de comprovação da eficácia e eficiência do NAT na diminuição do risco residual de transmissão transfusional de doenças infecciosas, fundamentaram tanto sua obrigatoriedade, no Brasil, pela Portaria no 2.712/2013 do Ministério da Saúde e pela Resolução da Diretoria Colegiada (RDC) ํo 51/2013 da Agência Nacional de Vigilância Sanitária (ANVISA), quanto à inclusão dos critérios técnicos estabelecidos para realização do NAT na triagem de doadores de sangue, no âmbito do SUS, pela Portaria no 25/2013 da Comissão Nacional de Incorporação de Tecnologias no SUS (CONITEC) e pela Portaria Conjunta no 239/2014 (BRASIL, 2013b; d; c; 2014b; c).

Em 2012, a Hemorrede Brasileira apresentou, 3.637 .775 coletas de sangue, dos quais $93,13 \%$ dessas coletas e $88,55 \%$ das transfusões são realizadas no Sistema Único de Saúde (SUS) (BRASIL, 2014a). Dessa forma, a importância da disponibilização e obrigatoriedade do NAT em complemento aos testes sorológicos 
atuais, contribui para redução do risco residual e aumento da segurança transfusional (AABB, 2011).

Existem três kits comerciais NAT aprovados pelo Ministério da Saúde e com registro na ANVISA para utilização na triagem laboratorial de doadores de sangue. Desses, dois são fabricados por empresas multinacionais e o outro é produzido nacionalmente (ANVISA; Petry, 2013). O kit fabricado pela Gen-Probe Incorporated ${ }^{\circledR}$, Procleix Ultrio Assay® ${ }^{\circledR} \mathrm{HV} / \mathrm{HBV} / \mathrm{HCV}$, utiliza como metodologia a amplificação mediada por transcrição (TMA) que por meio de um ciclo contínuo de replicação do material genético e com temperatura constante, sintetiza ao final, múltiplas cópias de ácido ribonucleico (RNA) do segmento de material genético alvo. Sua plataforma é considerada totalmente automatizada, permitindo a realização do teste tanto em amostras individuais ou em pool de tamanhos variados (Mullis et al., 1986; Grant e Busch, 2002; Gen-Probe, 2011).

O outro kit é o Cobas S201 TaqScreen MPX® HIV/HBV/HCV, fabricado pela Roche Molecular Systems Incorporated ${ }^{\circledR}$, que utiliza como metodologia uma variação da reação em cadeia da polimerase (PCR), a PCR em tempo real (RT-PCR real time), que consiste em uma reação de transcrição reversa prévia catalisada pela enzima transcriptase reversa, responsável por sintetizar cópias de ácido desoxirribonucleico (DNA) a partir do material genético alvo (RNA viral), seguida da PCR que, utilizando sequências iniciadoras (primers) complementares ao fragmento alvo, bases nitrogenadas, íons, enzima polimerase e três etapas distintas de temperatura (desnaturação, acoplamento de primers e extensão) permitem a amplificação exponencial de uma determinada sequência do material genético de interesse. Ainda, pela incorporação de sondas fluorescentes à reação, a amplificação desse material genético pode ser visualizada em tempo real, uma vez que a emissão de sinal fluorescente na fase exponencial da reação é proporcional à quantidade de DNA alvo na amostra. Essa plataforma de testes é semi-automatizada e permite o processamento de pool de seis amostras e amostras individuais (Mullis et al., 1986; Grant e Busch, 2002; Roche, 2009b; a).

Os dois testes citados acima possibilitam a detecção dos vírus HIV, HCV e HBV em uma mesma reação, no entanto há necessidade de se utilizar um kit 
complementar para discriminação dos vírus em caso de amostras positivas (Roche, 2009b; Gen-Probe, 2011).

O kit NAT HIV/HCV Bio-Manguinhos® é produzido nacionalmente pela Fundação Oswaldo Cruz e, analogamente ao Cobas S201 TaqScreen MPX® HIV/HBV/HCV, utiliza como metodologia de detecção a RT-PCR real time e processa em rotina tanto amostras individuais quanto pool constituído por seis amostras em plataforma semi-automatizada. O kit nacional detecta os vírus HIV, HCV e HBV, em uma mesma reação, e possibilita a identificação discriminatória desses quando presentes na amostra positiva, não sendo necessária a utilização de kit complementar (Bio-Manguinhos/FIOCRUZ, 2011). 


\section{OBJETIVOS}

\section{OBJETIVO GERAL}

Este trabalho tem por objetivo elaborar um manual técnico que reúna todos os procedimentos, de forma sistematizada e criteriosa, para a implantação do controle de qualidade interno para os testes de amplificação de ácidos nucleicos (CQI-NAT) no serviço de hemoterapia do Hemocentro de Ribeirão Preto.

\subsection{OBJETIVOS ESPECÍFICOS}

- Desenvolver protocolos padronizados para produção do CQI-NAT pelo Hemocentro de Ribeirão Preto;

- Estabelecer os critérios de aceitação para utilização do CQI-NAT na rotina de testes;

- Analisar a reprodutibilidade do CQI-NAT proposto;

- Auxiliar e orientar a Hemorrede quanto à utilização do CQI-NAT, para triagem laboratorial de doadores de sangue, considerando as fases analíticas e pósanalíticas do processamento dos testes. 


\section{CAPÍTULO I}

Principais vírus transmissíveis por transfusão com triagem disponível pelo NAT

Vírus da Imunodeficiência Humana (HIV)

Vírus da hepatite tipo B (HBV)

Vírus da hepatite tipo $\mathrm{C}(\mathrm{HCV})$ 


\section{CAPÍTULO I}

\section{Principais vírus transmissíveis por transfusão com triagem disponível pelo NAT.}

\subsection{Vírus da Imunodeficiência Humana (HIV)}

O HIV é um vírus da família Retroviridae e possui classificação em quatro grandes grupos, M, N, O e P e, estes em diversos subtipos, sub-subtipos e, ainda em formas recombinantes circulantes (CRF). São vírus constituídos por duas fitas idênticas de ácido ribonucleico (RNA), envolvidas pelas proteínas que compõem o capsídeo (p24) e o nucleocapsídeo, onde também estão presentes as enzimas (transcriptase reversa, protease e integrase) responsáveis pela replicação e integração do material genético viral na célula hospedeira (Goto, Nakai e Ikuta, 1998; Turner e Summers, 1999).

O seu genoma, é composto por genes estruturais (gag, pol e env), comuns aos retrovírus, além de seis origens de replicação (do inglês, open reading frame, ORF) responsáveis pela codificação de proteínas reguladoras da transcrição viral e proteínas auxiliares (Gelderblom, Ozel e Pauli, 1989; Bordin, Langhi e Covas, 2007).

O curso da infecção pelo HIV é definido pelas fases de latência; na qual há replicação viral restrita ao parênquima ou local de inoculação e, devido à sensibilidade analítica dos testes atuais não é possível à detecção dessas partículas (Fiebig et al., 2003; Busch et al., 2005); fase de replicação com a disseminação viral no sangue periférico, estabelecimento da infecção e possibilidade de deteç̧ão do RNA viral e do antígeno p24 e, finalmente fase de platô, que apresenta carga viral constante. Após essa última fase, ocorre o período de soroconversão, no qual é possível a detecção de anticorpos anti-HIV (Kleinman, Lelie e Busch, 2009).

Os dados epidemiológicos demonstram que aproximadamente 718 mil pessoas vivem com HIV/Aids no Brasil, com notificação média de 37.446 novos casos por ano (BRASIL, 2013a). Entre 2007 a 2013, foram feitas 58 notificações de doenças transmissíveis por transfusão no Sistema de Notificação em Vigilância Sanitária - 
NOTIVISA/ANVISA/MS, sendo que dessas, 11 casos concluídos e confirmados correspondem à transmissão transfusional de HIV (Brasil, 2014d).

$\mathrm{Na}$ triagem laboratorial para o HIV, realizada pelos serviços de hemoterapia brasileiros, é preconizado o uso de dois tipos diferentes de testes, um ensaio do tipo ELISA, ou um teste de detecção combinada, que identifica o anticorpo anti-HIV e o antígeno viral específico (p24) em 22 dias após a infecção, e o NAT, que detecta o RNA viral após 11 dias de infecção (Schreiber, 1996; Sabino et al., 1999; Stramer et al., 2004; BRASIL, 2013b). Para realização de exames confirmatórios, quando realizados por estes serviços de hemoterapia, são utilizados o teste Western Blotting e a imunofluorescência indireta.

\subsection{Vírus da hepatite tipo B (HBV)}

Em 1963 foi descoberto no soro de um aborígene na Austrália, um antígeno que reagia em contato com soro de hemofílicos que tinham sido poli transfundidos, sendo atribuído a este antígeno a denominação de antígeno Austrália que posteriormente foi denominado antígeno de superfície da hepatite $B(\mathrm{HBs} A g)$. (Blumberg, 1965; Blumberg,1966). Desse modo a Hepatite tipo B foi a primeira infecção identificada como passível de transmissão transfusional, com a transfusão de hemoderivados associada ao desenvolvimento de hepatite clínica (Dane, 1970; Dwyre, Fernando e Holland, 2011).

O HBV pertence à família Hepadnaviridae e é classificado em oito genótipos, de $A-H$, possui três tipos de partículas virais. Duas com formato de filamentos e esferas, compostas pelo HBsAg e lipídios do hospedeiro e portanto, não são consideradas infecciosas. A terceira partícula, o HBV infeccioso, além de possuir em sua estrutura o envelope lipídico contendo HBsAg, apresenta um nucleocapsídeo interno composto de antígeno do núcleo, ou core, (HBcAg), uma enzima polimerase e o material genético constituído de dupla fita de ácido desoxirribonucleico (DNA) circular, que pode integrar-se ao DNA das células hepáticas dos indivíduos 
infectados. Cada gene presente no genoma é responsável pela codificação de diferentes antígenos relacionados à replicação viral e infecção (Liang, 2009).

O estudo das infecções por hepatites virais, realizado entre 2005 e 2009, nas capitais do Brasil, demonstrou uma prevalência de 7,4\% de HBV na população, considerando a positividade sorológica do anticorpo contra as proteínas do core do HBV, o anti-HBc. Os dados do Ministério da Saúde apontam discrepâncias entre as notificações do NOTIVISA/ANVISA/MS e no Sistema de Informação de Agravos de Notificação - SINAN/SVS/MS, sendo registrados 2 casos de HBV transfusional no primeiro sistema e 1.541 casos de HBV atribuído à transfusão sanguínea entre 2007 a 2011, no segundo sistema de notificação (Brasil, 2014d).

Dos adultos infectados com HBV, cerca de 90 a 95\% são consideradas curadas, com níveis do genoma viral indetectável pelos testes disponíveis. Entre as pessoas adultas infectadas, 5 a 10\% evoluem para a forma crônica da doença, porém quando a infecção acomete crianças, o risco de cronicidade é de $90 \%$ para aquelas com menos de um ano (BRASIL, 2005).

Atualmente, os testes sorológicos utilizados para triagem de doadores de sangue permitem a detecção do antígeno HBsAg e anticorpos anti-HBc, ambos possibilitam a caracterização da fase da doença, estando também disponível a realização do NAT para HBV (BRASIL, 2013b).

Entretanto, mesmo com a alta sensibilidade e especificidade, os testes ainda apresentam um percentual considerável de resultados falsos positivos e após o contato com o vírus, o período de janela imunológica pode variar de 20 a 30 dias (Kleinman, Lelie e Busch, 2009; Kosan et al., 2010; Dwyre, Fernando e Holland, 2011).

\subsection{Vírus da hepatite tipo C (HCV)}

Outro importante vírus para a triagem laboratorial nos serviços de hemoterapia é o HCV, em que a transfusão de sangue apresenta-se como segunda maior fonte de transmissão $(26,9 \%)$, com prevalência de $1,38 \%$ na população brasileira segundo 
estudo das infecções por hepatites virais, realizado entre 2005 e 2009 nas capitais do país. (Donahue et al., 1992; Bordin, Langhi e Covas, 2007; BRASIL, 2012). Também os dados dos sistemas de informação do Ministério da Saúde sobre a transmissão transfusional do $\mathrm{HCV}$, são divergentes, sendo que conforme 0 NOTIVISA/ANVISA/MS, foram concluídos e confirmados 5 casos entre 2007 a 2013 e no SINAN/SVS/MS foram notificados 6.622 casos entre 2007 a 2011 (Brasil, 2014d).

Aproximadamente $80 \%$ das pessoas infectadas pelo $\mathrm{HCV}$ evoluem para as formas crônicas da doença e os $20 \%$ restante eliminam o HCV em um período de seis meses após infecção e são consideradas curadas, com níveis do genoma viral indetectável pelos testes disponíveis atualmente.

O HCV está classificado na família Flaviviridae, gênero Hepacivirus, e dividido em sete genótipos principais, nomeados de um a sete, contando com mais de 80 subtipos.

O vírus é constituído por molécula de RNA de fita simples, nucleocapsídeo e envelope. Possui genes que codificam as proteínas estruturais, necessárias para montagem das novas partículas e, proteínas não estruturais, relacionados com o complexo de replicação viral, que ocorre exclusivamente no citoplasma da célula hospedeira (Simmonds et al., 1993; Simmonds, 2004).

Nos serviços de hemoterapia, a detecção do HCV é realizada geralmente por ensaio do tipo ELISA, que detecta anticorpos anti-HCV presentes no soro do candidato à doação (BRASIL, 2013b) em aproximadamente 70 dias após o contato viral e, também, por NAT que detecta o RNA viral após 12 dias de infecção (Schreiber, 1996; Busch et al., 2000; Kleinman, Lelie e Busch, 2009; Dwyre, Fernando e Holland, 2011). Outros ensaios de detecção de anticorpos específicos contra o HCV como aqueles utilizando antígenos aderidos a tiras de nitrocelulose, quantificação de carga viral e genotipagem do HCV, também tem sido empregados em serviços de hemoterapia como testes suplementares. 
A qualidade e o início do sistema de gestão aplicado aos serviços de hemoterapia

Conceito de qualidade

Os resultados do controle de qualidade como ferramenta de avaliação

Indicadores

Avaliação de indicadores e análise critica

Melhoria contínua da qualidade 


\section{CAPÍTULO II}

\section{A qualidade e o início do sistema de gestão aplicado aos serviços de hemoterapia.}

No Brasil, após 1916, foram implantados os serviços especializados na prática hemoterápica, e nesta ocasião a qualidade do produto hemoterápico era percebida pela seleção de doadores com boas condições de saúde. Na década de 40 , a temática da qualidade na seleção dos candidatos à doação, nas transfusões, na segurança e comodidade e no atendimento dos doadores e pacientes era amplamente abordada no âmbito desses serviços (JUNQUEIRA, ROSENBLIT e HAMERSCHLAK, 2005).

No ano de 1980, foi criado o Programa Nacional de Sangue e Hemoderivados para organização e edição de normas de regulamentação da atividade hemoterápica. Em seguida, o programa contou com a criação de uma comissão responsável por implantar nos serviços de hemoterapia as diretrizes para a não comercialização de sangue; para o atendimento universal da população e para a qualidade na prestação dos serviços. Além disso, a cooperação técnica entre a França e o Brasil apresentou grande importância na implantação de padrões internacionais de segurança transfusional e de qualidade, inclusive em relação à utilização dos controles de qualidade na rotina laboratorial (JUNQUEIRA, ROSENBLIT e HAMERSCHLAK, 2005).

Entretanto, as ações e percepções de qualidade, nos serviços de hemoterapia, somente tiveram um efetivo alcance social em 1998 quando o governo Federal lançou como tema da Meta Mobilizadora Nacional do Setor de Saúde o "sangue com garantia de qualidade em todo o seu processo até 2003", fortalecendo a prática hemoterápica brasileira com qualidade e segurança transfusional (BRASIL, 1999). 


\section{Conceito de qualidade}

O conceito de qualidade teve seu marco histórico em 1920, com o início da era industrial e a produção em massa e, nessa época, estava relacionado à inspeção do produto final. A evolução, desde o primeiro conceito, possibilita atualmente a análise de todos os processos envolvidos com a produção e a satisfação do usuário e, nesse contexto, é possível definir a qualidade esperada de determinado serviço ou produto final considerando a avaliação de seus processos de produção (Malik e Schiesari, 1998).

Assim, a avaliação da qualidade deve seguir critérios previamente estabelecidos e em conformidade com o produto ou serviço oferecido, além de utilizar-se das ferramentas disponíveis, dentro do escopo do sistema de gestão da qualidade, para o monitoramento de todo o processo (Malik e Schiesari, 1998).

A interação entre os processos, produtos e serviços, ferramentas de avaliação, o monitoramento e documentação configuram o sistema de gestão da qualidade, por meio do qual é possível o gerenciamento e a prevenção de não conformidades, alcançando continuamente melhores resultados (Malik e Schiesari, 1998; ABNT, 2008b; a; Técnicas, 2008).

No âmbito dos serviços de hemoterapia, a relação entre o hemocentro, 0 doador e o paciente conforma uma interação cliente-fornecedor. Assim, o sistema de gestão da qualidade, quando relacionado com os serviços de hemoterapia, possibilita a padronização dos procedimentos, adequação e controle dos processos, desde a seleção de doadores até a transfusão sanguínea, permitindo o atendimento às legislações vigentes e a constante melhoria da qualidade dos hemocomponentes oferecidos e dos serviços prestados (Malik e Schiesari, 1998). 


\section{Os resultados do controle de qualidade como ferramenta de avaliação}

Para monitorar e mensurar a qualidade, no início dos anos 30, W. A. Shewhart propôs a aplicação, no escopo da gestão da qualidade, de gráficos de controle, desenvolvidos para auxiliar na melhoria da produção industrial, na oferta dos serviços e na diminuição dos custos. Posteriormente, outras ferramentas estatísticas, padrões, indicadores e avaliações possibilitaram comparações internas e externas, monitoramento dos processos e avaliação do desempenho institucional (Deming, 1990; Malik e Schiesari, 1998).

Em 1950, as técnicas para monitorar e mensurar a qualidade industrial foram adaptadas por Levey-Jennings que, baseado nos gráficos de controle de Shewhart, utilizou plasma congelado com resultados conhecidos para controle dos ensaios laboratoriais. Analogamente ao aplicado na indústria, aos resultados obtidos pelo processamento do plasma nos ensaios laboratoriais, eram realizadas análises estatísticas e definidos limites de aceitação para os ensaios. Em 1981, James Westgard descreveu o uso de regras múltiplas, com combinação de vários critérios que podem determinar a aceitabilidade de uma corrida analítica. Tais regras são atualmente aplicadas para o controle de qualidade interno da triagem sorológica realizada nos serviços de hemoterapia (Westgard et al., 1981; Oliveira e Mendes, 2011).

Também, em 1980, a avaliação da qualidade em saúde de maneira global, foi descrita por Avedis Donabedian considerando a estrutura, os processos e os resultados no âmbito dos sistemas de saúde, atendendo assim a avaliação dos recursos físicos, disponibilidade de profissionais capacitados, existência de equipamentos e manutenções e, organização dos serviços. Posteriormente o conceito de qualidade foi ampliado e a ele foram introduzidas as temáticas de eficácia, efetividade, eficiência, otimização, aceitabilidade, legitimidade e equidade (Donabedian, 1994; Malik e Schiesari, 1998). 
O controle de qualidade dentro do escopo atual do sistema de gestão da qualidade é atualmente uma das ferramentas que, quando aplicada em conjunto com a rotina de testes de triagem laboratorial dos serviços de hemoterapia, possibilita monitorar a reprodutibilidade, ou seja, avaliar o desempenho de um método validado durante seu uso na rotina, controlar e acompanhar o processo com base em dados estatísticos e, indicar aceitação ou rejeição de um determinado resultado conforme os limites estabelecidos como aceitáveis, evidenciando a necessidade de repetição de uma rotina que esteja fora dos padrões (THOMPSON e WOOD, 1995; van der Voet, van Rhijn e van de Wiel, 1999). Ainda, a análise crítica dos dados estatísticos ou indicadores fornecidos pelo controle de quelidade, permite a identificação de possíveis erros aleatórios ou sistemáticos, que podem impactar negativamente na qualidade dos resultados finais (ISO:9000, 2005; Sakuma, Ottoboni e Sierra, 2011).

As causas de erros identificadas podem ser previstas e corrigidas pela aplicação de ações preventivas ou corretivas, considerando o treinamento técnico dos profissionais responsáveis pela execução dos testes, a realização das técnicas conforme os procedimentos operacionais padrão (POP), a estrutura do laboratório, os equipamentos utilizados, o armazenamento dos insumos, a conservação dos registros gerados e sua recuperação e, os métodos empregados. Portanto, todo o conjunto de processos deve trabalhar em consonância para produção de resultados qualificados e confiáveis, sendo o controle de qualidade uma responsabilidade compartilhada entre toda equipe (Sakuma, Ottoboni e Sierra, 2011).

\section{Indicadores}

O principal objetivo dos indicadores é o acompanhamento dos padrões e metas estabelecidas, auxiliando no sistema de gestão da qualidade e nas ações de planejamento e melhoria continua. $\mathrm{O}$ bom indicador deve fornecer parâmetros para avaliação dos processos além de demonstrar a confiabilidade dos resultados obtidos (Malik e Schiesari, 1998).

Como característica, um indicador deve ser implementado para avaliar casos em que existam ou possam existir potenciais problemas na qualidade, sendo 
desejável que o mesmo auxilie na definição de não conformidades com especificidade, evidência, disponibilidade de dados, comparabilidade, validade, análise evolutiva e custo-efetividade (Mainz, 2003).

Dessa maneira, considerando as definições para os indicadores, podemos transpor a interpretação de que os dados do controle de qualidade interno podem ser considerados indicadores de efetividade e eficiência do processo, demonstrando que os resultados esperados são alcançados com o uso eficaz dos recursos disponíveis (Malik e Schiesari, 1998).

\section{Avaliação de indicadores e análise critica}

A análise de indicadores não pode ser realizada de maneira isolada, devendo considerar também os critérios de estrutura, do processo, os resultados esperados e as condições nas quais os dados estão sendo reproduzidos. Dessa forma, depois de estabelecida a sistemática de avaliação e monitoramento, é possível utilizar os indicadores para propor adequações de planejamento, ações preventivas e de melhoria continua (Malik e Schiesari, 1998).

Após verificação dos resultados apresentados pelo grupo de indicadores e identificação de uma potencial e possível não conformidade inerente ao processo, é necessário elaboração de plano de ação, adotando uma das ferramentas que o sistema de gestão da qualidade oferece. Como conclusão, torna-se possível, pela análise crítica dos indicadores de controle de qualidade interno, a proposição de soluções eficazes e a antecipação da tratativa aos problemas em potencial, que podem gerar variações desnecessárias ao processo, produto ou serviço (Deming, 1990).

\section{Melhoria contínua da qualidade}

As ações de melhoria devem ser tratadas de maneira organizada com foco na identificação e prevenção das potenciais não conformidades. De maneira prática, 
com a utilização das ferramentas da qualidade é possível identificar ações e soluções utilizando-se o denominado ciclo PDCA (Planejar-Fazer-Verificar-Agir ou Plan-Do-Check-Act) (Malik e Schiesari, 1998).

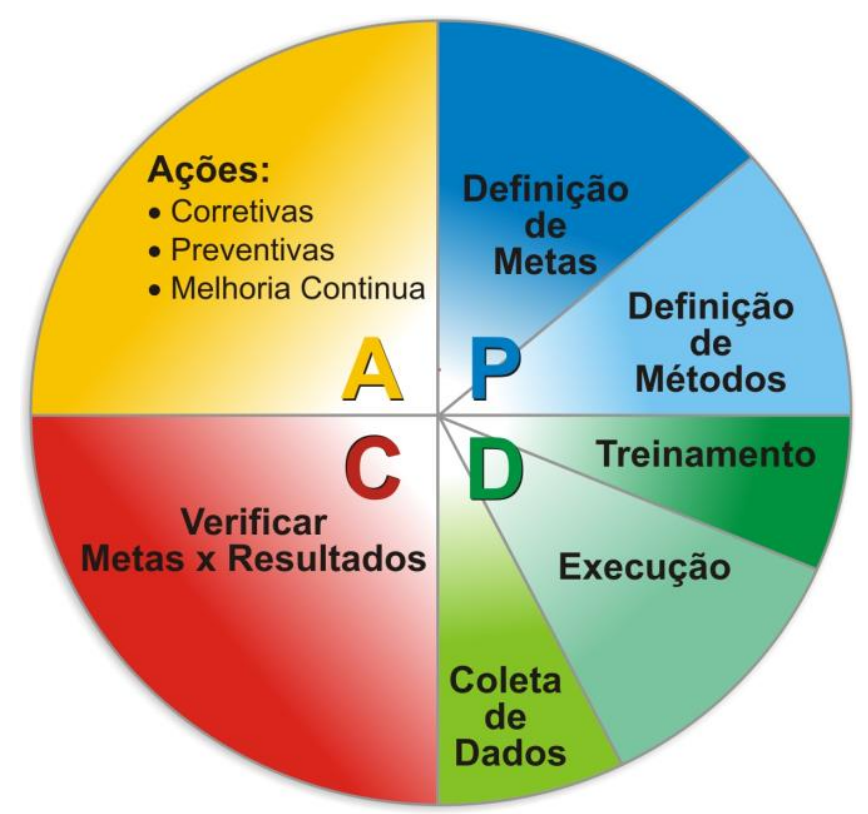

Figura 1: Ciclo Plan, Do, Check, Act (PDCA). Ferramenta de gestão da qualidade que tem como ponto inicial: o planejamento (do inglês, plan) no qual há definição das metas para um determinado processo; o fazer (do inglês, do) que compreende as fases de treinamento, execução e coleta de dados para verificar (do inglês, check) o cumprimento das metas e alcance dos resultados. Posteriormente, o processo pode ser aprimorado com base nas ações (do inglês, action) corretivas, preventivas e de melhoria contínua. Esquema modificado a partir de: http://www.qualidade.wikidot.com/ciclo-pdca.

O controle de qualidade e o acompanhamento dos resultados podem ser identificados no ciclo PDCA no momento da verificação (checar), que é essencial para avaliar os resultados frente ao planejamento e identificar evidências de atendimento aos objetivos propostos.

A realização do controle de qualidade na rotina de triagem laboratorial de doadores de sangue, inclusive no NAT, é preconizada conforme as Portarias Ministeriais no 1.544/1997 e $n^{\circ} 2.712 / 2013$, com o objetivo de assegurar ao produto final e ao serviço oferecido um padrão ótimo de qualidade (BRASIL, 1996; 2013b) 
Em laboratórios analíticos, o controle de qualidade é dividido em dois tipos, o controle de qualidade interno (CQI), no qual amostras conhecidas, padronizadas pelo próprio laboratório ou adquiridas comercialmente, são testadas rotineiramente para monitorar os procedimentos da fase analítica, detectando erros ou variações intralaboratoriais, e o controle da qualidade externo (CQE), que consiste na aplicação de ensaios de proficiência, pelo processamento de amostras ou painéis com resultados conhecidos somente pelo produtor do CQE, distribuídos entre diferentes laboratórios, para avaliação e monitoramento contínuo do desempenho (Valentine-Thon, 2002; Laperche et al., 2009).

Assim, seguindo o escopo do sistema de gestão da qualidade e a padronização dos procedimentos, após introdução do NAT na rotina de testes de triagem laboratorial dos doadores da Hemorrede nacional, é recomendada a realização de CQI para as rotinas e para a validação dos lotes dos conjuntos diagnósticos (BRASIL, 2013b). Sendo possível evidenciar, com um CQI padronizado, tanto variações no desempenho a cada novo lote utilizado, quanto possíveis erros ou desvios inerentes ao processamento da rotina.

Cabe ressaltar que, de maneira distinta, ao empregar os controles fornecidos pelo fabricante juntamente com os conjuntos diagnósticos, é possível validar o ensaio e os resultados das amostras referentes àquela determinada rotina de testes, porém a percepção e identificação de variações relacionadas ao processo, bem como a ocorrência de possíveis erros sistemáticos ou aleatórios, podem ser dificultadas pelo uso de amostras-controle não padronizadas internamente. 


\section{CAPÍTULO III}

\section{Procedimentos Operacionais Padrão (POP)}

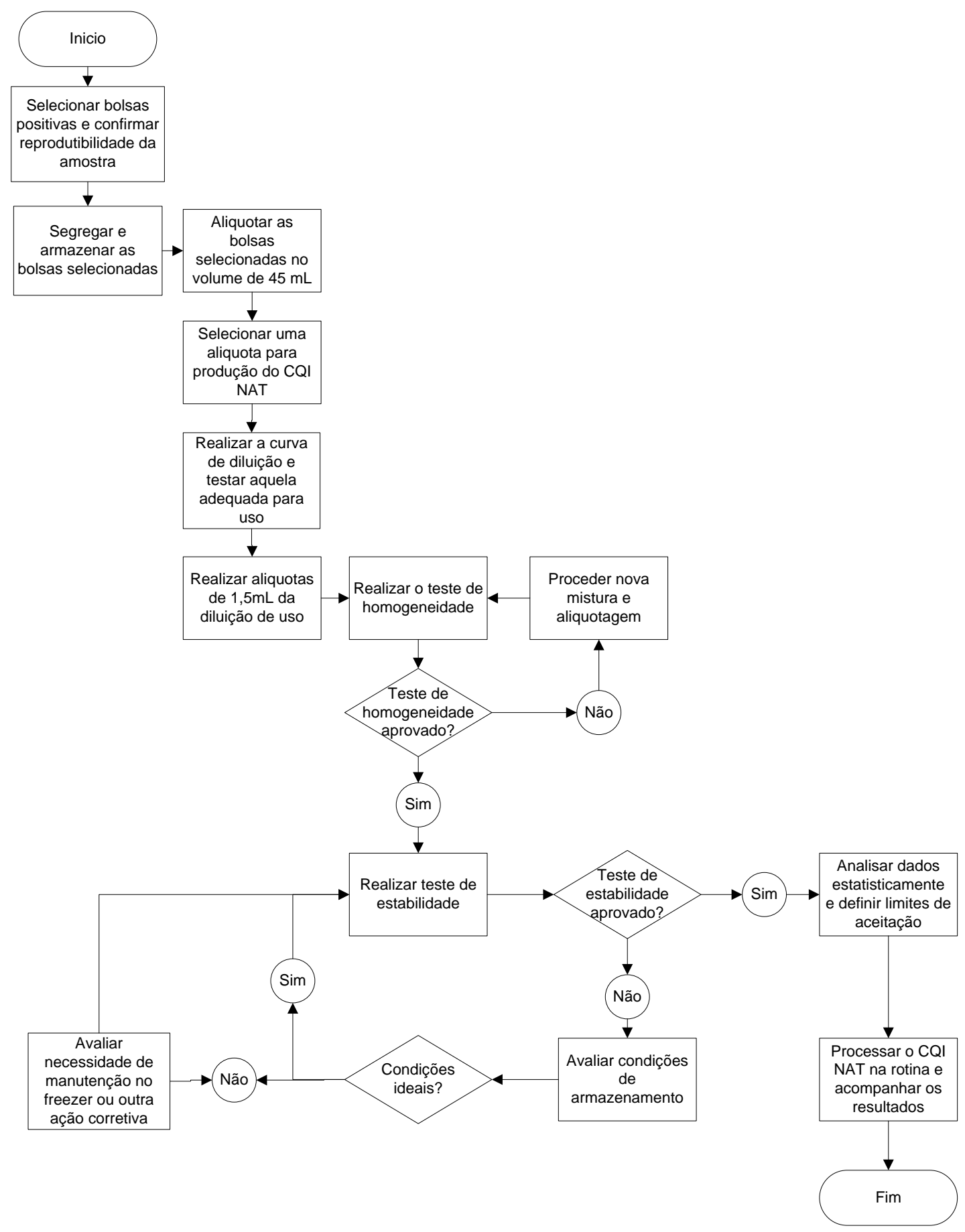

Figura 2: Fluxograma para produção e validação do CQI-NAT. As formas ovais indicam o início e o final do processo; os retângulos indicam as fases do processo; os losangos recomendam uma decisão; os círculos são conectores que indicam as decisões e as setas apontam o fluxo de informação através do fluxograma. 
O fluxograma apresentado na figura 2 descreve a sequência de etapas para confecção e validação do CQI-NAT. De forma resumida, as bolsas positivas para confecção do CQI-NAT foram obtidas de doações voluntárias realizadas no Hemocentro de Ribeirão Preto e cedidas ao estudo com consentimento livre e esclarecido do doador, por meio de termo de consentimento, assinado no momento da triagem clínica.

Os protocolos de produção e uso do CQI-NAT foram elaborados e validados na rotina do laboratório NAT do Hemocentro de Ribeirão Preto, utilizando-se o Kit NAT $\mathrm{HIV} / \mathrm{HCV}$, fabricado nacionalmente por Bio-Manguinhos, e a plataforma de equipamentos do NAT nacional, composta pelo pipetador Janus (Perkin Elmer), o extrator e purificador ácidos nucleicos Biorobot MDX (Qiagen) e o termociclador ABI 7500 (Life Technologies) para amplificação e detecção dos ácidos nucleicos (BioManguinhos/FIOCRUZ, 2011; Petry, 2013).

A padronização dos protocolos e a validação da estabilidade e homogeneidade do CQI-NAT foram realizadas conforme recomendado pelas normas ISO 17025:2006 e 17043:2011, que dispõem sobre os requisitos gerais para laboratórios de ensaio e calibração e avaliação de conformidade para ensaios de proficiência (ABNT, 2006; 2011). Foi calculado desvio padrão e coeficiente de variação e a média tanto para os dados de processamento das 20 réplicas da diluição, para cada vírus alvo, selecionada como ideal para uso na rotina, quanto para os dados do teste de homogeneidade e estabilidade do CQI-NAT produzido. Os limites de aceitação do gráfico de dispersão, para acompanhamento dos dados do CQI-NAT na rotina, foram propostos considerando uma curva de distribuição gama e as análises estáticas dos resultados de Cycle Threshold (Ct) de 20 réplicas da diluição selecionada para uso.

Como forma de possibilitar a rastreabilidade dos dados desde a seleção da bolsa positiva, diluição e preparo das amostras, realização dos testes de homogeneidade e estabilidade e uso do CQI-NAT na rotina diária, foram propostas planilhas para registros das informações referentes a todo o processo, de acordo com os princípios da qualidade e das boas práticas de fabricação (ABNT, 2008a). 
Caso o CQI-NAT, durante seu processamento na rotina, apresentasse valores fora dos limites de aceitação estabelecidos, os resultados das amostras não eram considerados válidos e a rotina NAT, repetida. 


\subsection{SELEÇÃO DAS BOLSAS PARA PRODUÇÃO DO CQI-NAT}

\section{OBJETIVO:}

Selecionar bolsas de plasma de doadores, previamente triadas pela sorologia e NAT e que apresentem resultados positivos para os vírus alvo do NAT utilizado na rotina do serviço de hemoterapia.

\section{AMOSTRAS:}

Bolsas de Plasma Fresco Congelado (PFC), positivas unicamente para os vírus de interesse e, negativas para os demais parâmetros sorológicos triados.

\section{MATERIAIS:}

- Computador com acesso ao sistema do ciclo do sangue e resultados sorológicos e do NAT;

- Sacos plásticos transparentes;

- Teste do Ácido Nucleico - NAT, conforme utilizado na rotina diária do serviço de hemoterapia;

- Etiquetas de identificação do material.

\section{PROCEDIMENTO:}

a) Pesquisar no sistema do ciclo do sangue para identificação das bolsas positivas para a produção do CQI-NAT;

b) Repetir na rotina NAT a amostra referente à bolsa selecionada em oito replicas e individualmente para avaliar sua reprodutibilidade;

c) Avaliar se as bolsas selecionadas apresentam resultados negativos/não reagente para os demais parâmetros sorológicos, como hepatite tipo $B$ (HBV), vírus linfotrópico de células T humanas tipo 1/2 (HTLV-1/2), sífilis e doença de Chagas;

d) Registrar os dados de identificação, volume, data da coleta e resultados de positividade referente à sorologia e NAT das bolsas selecionadas, conforme Apêndice I;

e) Segregar as bolsas positivas e armazenar na temperatura de $80^{\circ} \mathrm{C}$ negativos, em sacos plásticos transparentes, com etiquetas de identificação de risco biológico e de acordo com o disposto na norma da Associação Brasileira de Normas Técnicas - ABNT NBR 7500:2013, conforme Apêndice II. 


\subsection{ALIQUOTAGEM DAS BOLSAS POSITIVAS SELECIONADAS}

\section{OBJETIVO:}

Distribuir uniformemente todo o plasma fresco da bolsa positiva em frascos menores para facilitar posterior manipulação e preparo do CQI.

\section{AMOSTRAS:}

Bolsas de Plasma Fresco Congelado (PFC), positivas unicamente para os vírus de interesse e, negativas para os demais parâmetros sorológicos triados.

\section{MATERIAIS E EQUIPAMENTOS:}

- Pinça com trava e esterilizada;

- Tesoura esterilizada;

- Gaze estéril;

- Álcool 70\%;

- Tubos de polipropileno de fundo cônico com capacidade para $50 \mathrm{~mL}$;

- Estante suporte para tubos;

- Sacos plásticos;

- Equipo de transfusão simples;

- Homogeneizador automático para bolsas;

- Banho-maria;

- Capela de fluxo laminar;

- Equipamentos de proteção individual: luvas, jaleco descartável, óculos e máscara.

\section{PROCEDIMENTO:}

a) Paramentar-se adequadamente com os equipamentos de proteção individual;

b) Retirar as bolsas do freezer oitenta graus Celsius negativos $\left(-80^{\circ} \mathrm{C}\right)$ e dispor cada uma em sacos plásticos transparentes;

c) Levar as bolsas para o banho-maria e deixar descongelar completamente à temperatura de $37^{\circ} \mathrm{C}$;

d) Registrar o tempo e a temperatura de descongelamento das bolsas, conforme Apêndice III; 
Nota: deve-se ter cuidado no descongelamento para que a bolsa não rasgue e não haja derramamento de plasma positivo no banho-maria, contaminando0 .

e) Limpar a capela de fluxo laminar e o homogeneizador com álcool $70 \%$ por 3 vezes, aguardando o tempo de evaporação do álcool $70 \%$ antes de limpar novamente as superfícies;

f) Ligar a luz ultravioleta da capela de fluxo laminar por 20 minutos e registrar em planilha própria, conforme Apêndice IV;

g) Identificar os tubos com a data da aliquotagem, o número de identificação da bolsa, o patógeno para o qual o plasma é positivo, a temperatura de armazenamento como $80^{\circ} \mathrm{C}$ negativos e o responsável pelo procedimento, conforme Apêndice V;

h) Colocar todos os materiais e o homogeneizador dentro do fluxo laminar;

i) Colocar a bolsa de plasma no homogeneizador por 10 minutos em agitação média;

j) Limpar com gaze estéril e álcool $70 \%$ a extremidade que dá acesso ao conteúdo da bolsa de plasma e retirar o lacre de proteção;

k) Cortar a extremidade distal da câmara do equipo e descartá-la;

I) Pinçar a extremidade distal do equipo para que o plasma não extravase e inserir a agulha do equipo de transfusão na bolsa de plasma;

m)Transferir o plasma da bolsa para o tubo de polipropileno de fundo cônico, completando seu volume até $45 \mathrm{~mL}$;

Nota: repetir as etapas I, L e M, acima, até finalizar todo o conteúdo de plasma da bolsa;

Após realizar as alíquotas de uma bolsa positiva para determinado vírus, o fluxo deve ser novamente limpo e a luz ultravioleta ligada por 20 minutos e registrar em planilha própria, conforme Apêndice IV. Também deve ser utilizada outra tesoura e pinça com trava e esterilizada, para evitar contaminação das amostras com demais vírus.

n) Armazenar todas as alíquotas em freezer com temperatura de $80^{\circ} \mathrm{C}$ negativos, devidamente identificadas com etiqueta de risco biológico e de acordo com o disposto na norma da Associação Brasileira de Normas Técnicas - ABNT NBR 7500:2013, conforme Apêndice II;

o) Limpar e organizar da área de trabalho utilizada. 


\subsection{CURVA DE DILUIÇÃO E SELEÇÃO DA AMOSTRA IDEAL PARA PRODUÇÃO DO CQI-NAT}

\section{OBJETIVO:}

Realizar curva de diluição a partir da alíquota de $45 \mathrm{~mL}$ da bolsa positiva e selecionar a diluição ideal para produção do CQI-NAT.

\section{AMOSTRA:}

Alíquota de $45 \mathrm{~mL}$ de PFC preparada conforme procedimento 1.2, positiva para cada vírus alvo.

\section{MATERIAIS E EQUIPAMENTOS:}

- Estante suporte para tubos;

- Banho-maria;

- Tubos de polipropileno de fundo cônico com capacidade para $50 \mathrm{~mL}$;

- Plasma Humano Negativo, preparado conforme procedimento 1.8;

- Pipeta graduada de $10 \mathrm{~mL}$;

- Pipeta de 1.000 e de $200 \mu \mathrm{L}$ e ponteiras descartáveis;

- Papel absorvente para forrar a bancada;

- Álcool 70\%;

- Agitador de tubos;

- Equipamentos de proteção individual: luvas, jaleco descartável, óculos e máscara.

\section{PROCEDIMENTO:}

a) Paramentar-se adequadamente com os equipamentos de proteção individual;

b) Limpar a bancada de trabalho com álcool $70 \%$ e forrar com papel absorvente;

c) Descongelar em banho-maria na temperatura de $37^{\circ} \mathrm{C}$ uma alíquota de PFC positivo para cada vírus;

d) Identificar os tubos conforme tabela 1, abaixo.

Tabela 1: identificação dos tubos e diluições.

\begin{tabular}{|l|c|}
\hline Tubos & Solução Mãe \\
\hline Tubo 1 & Diluição 1:2 \\
\hline
\end{tabular}




\begin{tabular}{|l|c|}
\hline Tubo 2 & Diluição $1: 4$ \\
\hline Tubo 3 & Diluição 1:8 \\
\hline Tubo 4 & Diluição $1: 16$ \\
\hline Tubo 5 & Diluição $1: 32$ \\
\hline Tubo 6 & Diluição $1: 64$ \\
\hline Tubo 7 & Diluição $1: 128$ \\
\hline Tubo 8 & Diluição $1: 256$ \\
\hline Tubo 9 & Diluição $1: 512$ \\
\hline Tubo 10 & Diluição $1: 1024$ \\
\hline
\end{tabular}

- Preparo da solução mãe:

e) Em um tubo de fundo cônico de $50 \mathrm{~mL}$ adicionar PHN e a alíquota de plasma positivo para o vírus alvo, considerar o volume tanto o teste em pool quanto individual.

- Exemplo de diluição realizada para avaliação das amostras selecionadas para este trabalho:

- Para teste em pool:

Em um primeiro tubo, preparar a solução mãe para HIV, adicionando 39,375 mL de PHN e 625 uL do plasma positiva para HIV.

Em outro tubo, preparar a solução mãe para HCV, adicionando $39,687 \mathrm{~mL}$ PHN e 313 uL do plasma positivo para HCV.

- Para teste individual, adicionar $39,844 \mathrm{~mL}$ PHN e $156 \mathrm{uL}$ do plasma positivo para HIV.

Nota: os volumes para preparo da solução mãe devem considerar os valores dos Ct obtidos inicialmente na triagem.

\section{- Preparo da curva de diluição seriada:}

Nota: os volumes descritos abaixo se referenciam à curva de diluição seriada realizada com as amostras utilizadas neste trabalho.

f) Dispor na estante suporte para tubos os tubos de fundo cônico de $50 \mathrm{~mL}$;

g) Distribuir em cada um dos tubos, $5 \mathrm{~mL}$ de PHN utilizando a pipeta graduada; 
h) Adicionar ao tubo 1, 1,5 mL da solução mãe;

i) Tampar o tubo 1 e homogeneizar vigorosamente por 5 minutos;

j) Abrir o tubo 1, conservar a tampa e transferir $5 \mathrm{~mL}$ para o tubo $2 \mathrm{com}$ o uso da pipeta graduada;

Nota: repetir as etapas $\mathrm{H}, \mathrm{I}$ e $\mathrm{J}$ com os demais tubos, sucessivamente, conforme figura 3:

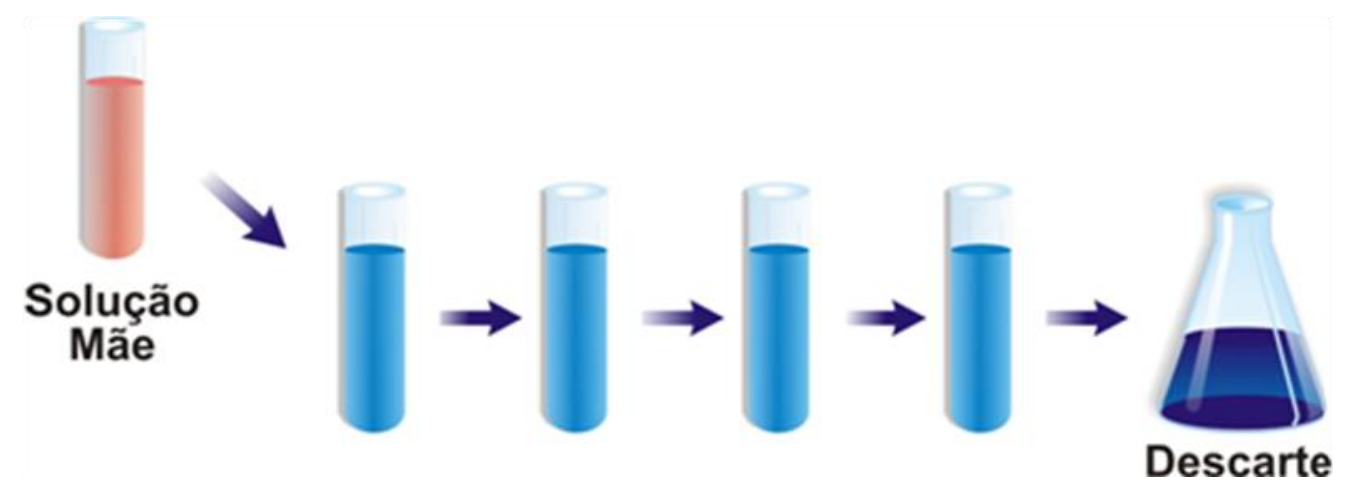

Figura 3: Esquema de diluição seriada. A figura demonstra esquematicamente a confecção da curva de diluição seriada em quatro diferentes concentrações (tubos azuis), a partir da solução mãe com a maior concentração de amostra positiva (tubo vermelho). Ao final, após homogeneização, o conteúdo de $5 \mathrm{~mL}$ do último tubo foi desprezado, mantendo a proporção de volume entre os tubos.

k) Desprezar, em descarte apropriado, o conteúdo de $5 \mathrm{~mL}$ do último tubo e realizar a etapa I no último tubo da curva;

I) Limpar e organizar da área de trabalho utilizada;

m) Submeter os tubos da curva de diluição seriada ao NAT, em duplicata para cada diluição.

Nota: caso o NAT no serviço de hemoterapia seja realizado em pool de amostras e individual, deve-se fazer a avaliação das curvas de diluição para essas duas situações específicas. Desse modo, no caso de utilização em pool, esses também devem ser testados em duplicata, utilizando para sua formação amostras da diluição seriada referente a cada vírus alvo e PHN. É recomendável que a pipetagem do pool seja realizada pelo equipamento da plataforma NAT.

\section{INTERPRETAÇÃO DOS RESULTADOS:}

a) Analisar os resultados das duplicatas selecionar a maior diluição em que 0 Ct da amostra positiva foi reprodutível; 
b) Após selecionar a diluição ideal de trabalho, realizar o NAT em 20 réplicas desta diluição para confirmação da sua reprodutibilidade;

Nota: para confirmação da reprodutibilidade da diluição deverão ser testadas 20 réplicas da diluição em pool composto pelas diluições das amostras dos vírus alvo selecionadas para uso e PHN. Os registros devem ser realizados conforme Apêndice VI.

c) Calcular, a partir dos resultados obtidos pelo processamento das 20 réplicas, a média, o desvio padrão (DP) e o coeficiente de variação $(\mathrm{CV})$ e definir valores de referência para esses parâmetros, conforme o lote de CQI-NAT produzido.

Nota: no CQI-NAT produzido foi utilizado critérios de coeficiente de variação abaixo de $10 \%$ a partir da média dos resultados de processamento de 20 réplicas da diluição selecionada para uso na confecção do CQI-NAT.

Cálculo da média $(\bar{X})$ : somar todos os valores $\left(\sum x\right)$ e dividir o resultado pelo número de elementos somados $(n)$.

$$
\bar{X}=\frac{\sum x}{n}
$$

Exemplo: $\bar{X}=\frac{x 1+x 2+x 3+\ldots+x 20}{20}$

Equação 1: esquema que descreve o cálculo utilizado para definição da média.

Cálculo do desvio padrão: extrair a diferença de cada valor $(x)$ em relação à média $(\bar{X})$; elevar todas as diferenças ao quadrado e somá-las; dividir o resultado por $(n-1)$, onde $(n)$ é o número de elementos somados e, extrair a raiz quadrada do resultado da divisão.

$$
S=\sqrt{\frac{\sum(x-\bar{X})^{2}}{(n-1)}}
$$

Exemplo:

$$
S=\sqrt{\frac{(x 1-\bar{X})^{2}+(x 2-\bar{X})^{2}+(x \ldots-\bar{X})^{2}+(x 20-\bar{X})^{2}}{19}}
$$

Equação 2: esquema que descreve o cálculo utilizado para definição do desvio padrão. 
Cálculo do coeficiente de variação ( $C V$ ): dividir o desvio padrão ( $S$ ) pela média dos resultados $(\bar{X})$ e multiplicar por 100 . O valor do coeficiente de variação é dado em porcentagem (\%).

$$
C V=\frac{S}{\bar{X}} \times 100
$$

Equação 3: esquema que descreve o cálculo utilizado para definição do coeficiente de variação.

d) Definir, conforme curva de distribuição gama, resultados das 20 réplicas da diluição ideal de trabalho e análise estatística pelo software de domínio público "R" (http://www.r-project.org/), os limites superiores e inferiores do gráfico controle para acompanhamento do CQI-NAT na rotina, conforme fórmula e programação abaixo:

library(MASS)

$x<-c(34.57,36.69,35.92,36.44,37.22,37.83,35.8,38.32,38.36$,

$37.57,36.28,38.85,41.27,40.85,46.14,36.73,34.91,34.89$,

$36.19,35)$

gammal <- function( $\mathrm{x}$,theta,k,lambda) \{

gammal <- $\left(\left(1 /\right.\right.$ (gamma $(\mathrm{k})^{*}$ theta^k) $) \quad$ * $(\mathrm{x} \text {-lambda })^{\wedge}(\mathrm{k}-1) \quad$ * $\exp (-(\mathrm{x}-$ lambda $) /$ theta $))^{\star}(\mathrm{x}>$ lambda $)+0 *(x<=$ lambda $\left.)\right\}$

$\operatorname{par}(\operatorname{mar}=c(5,3,1,1.5))$

$\min <-\operatorname{trunc}(\min (x))$

hist(x,prob=T,ylim=c(0,.25),ylab="Densidade",main="POOL HIV",xlab="Valor Ct")

a $<$-fitdistr(x,gammal,list(theta $=2, k=2$ ), lambda $=$ min)

curve(gammal(x,a\$estimate[1], a \$estimate[2], $\min ), x \lim =c(0,100), a d d=T, c o l=" b l$ ue",n=1000,ylim $=c(0, .25))$

min+qgamma(0.025, shape=a $\$$ estimate[1],scale=a\$estimate[2])

min+qgamma $(0.975$, shape $=$ a\$estimate[1],scale $=a \$ e s t i m a t e[2])$

min+qgamma $(0.05$, shape $=a \$$ estimate[1],scale=a\$estimate[2])

min+qgamma(0.95, shape=a\$estimate[1],scale=a\$estimate[2])

Equação 4: Descrição exemplificada das linhas de comando $R$ para a geração dos intervalos de limite superior e inferior do gráfico do CQI-NAT

Nota: na amostra com diluição selecionada para produção do CQI-NAT, pode ser realizada a quantificação da carga viral. 


\subsection{DILUIÇÃO E PREPARO DO CQI-NAT}

\section{OBJETIVO:}

Preparar as amostras de CQI-NAT conforme diluição e critérios definidos no protocolo 1.3.

\section{AMOSTRA:}

Alíquota de $45 \mathrm{~mL}$ de PFC preparada conforme procedimento 1.2, positiva para cada vírus alvo.

\section{MATERIAIS E EQUIPAMENTOS:}

- Etiquetas de identificação, conforme Apêndice VII;

- Estante para tubos;

- Tubos de polipropileno de fundo cônico com capacidade para $50 \mathrm{~mL}$;

- Microtubos de polipropileno de 1,5 mL;

- Pipeta de $1.000 \mu \mathrm{L}$ e ponteiras descartáveis;

- Pipeta graduada de $25 \mathrm{~mL}$;

- Plasma Humano Negativo, preparado conforme procedimento 1.7;

- Banho-maria;

- Agitador de tubos;

- Papel absorvente para forrar a bancada;

- Álcool 70\%;

- Caixa tipo rack, para armazenamento;

- Equipamentos de proteção individual: luvas, jaleco descartável, óculos e máscara.

\section{PROCEDIMENTO:}

a) Paramentar-se adequadamente com os equipamentos de proteção individual;

b) Limpar a bancada de trabalho com álcool $70 \%$ e forrar com papel absorvente;

c) Descongelar em banho-maria na temperatura de $37^{\circ} \mathrm{C}$ uma alíquota de PFC positivo para cada vírus;

d) Utilizar a fórmula abaixo para encontrar os volumes necessários à diluição da amostra positiva com plasma humano negativo (PHN): 
$40 \mathrm{~mL}$ (volume final) = volume da alíquota positiva $(\mathrm{mL})+\mathrm{PHN}(\mathrm{mL})$

Equação 5: esquema de cálculo utilizado para diluição da amostra positiva com PHN.

Nota: utilizar $40 \mathrm{~mL}$ como volume final para facilitar a homogeneização no tubo de polipropileno de fundo cônico de $50 \mathrm{~mL}$.

e) Dividir $40 \mathrm{~mL}$ pela diluição ideal, conforme seleção realizada no protocolo 1.3, para encontrar o volume $(\mathrm{mL})$ necessário da alíquota positiva a ser acrescido;

Nota: a diferença entre a o volume final e o volume da alíquota positiva corresponde ao volume necessário de $\mathrm{PHN}$ que deve ser acrescido à mistura.

\section{- Exemplo:}

- Concentração desejada $=1: 64$.

- Volume final $=40 \mathrm{~mL}$

- $40 \mathrm{~mL}$, dividido por $64=0,625 \mathrm{~mL}$, que corresponde ao volume da alíquota positiva a ser acrescido.

○ 0,625 mL, subtraído de $40 \mathrm{~mL}=39,375 \mathrm{~mL}$, que corresponde ao volume de PHN a ser acrescido.

Nota: os volumes descritos acima se referenciam ao preparo do CQI-NAT deste trabalho, conforme diluição selecionada como ideal considerando o valor de $\mathrm{Ct}$ da amostra inicial.

f) Adicionar ao tubo de polipropileno de fundo cônico os volumes de PHN e alíquota positiva e homogeneizar delicadamente por 10 minutos;

g) Transferir $1.000 \mu \mathrm{l}$ do tubo de fundo cônico para o microtubo de 1,5 $\mathrm{mL}$ e, a cada transferência, o conteúdo do tubo de fundo cônico deve ser homogeneizado aproximadamente cinco vezes com a pipeta de $1.000 \mu$;

Nota: após descongelamento do tubo de fundo cônico com $45 \mathrm{~mL}$ do plasma positivo, preparado conforme protocolo 1.2, a parte do conteúdo que não for utilizada deve ser aliquotada em microtubo de $1,5 \mathrm{~mL}$ e identificados como plasma positivo e armazenados a $80^{\circ} \mathrm{C}$ negativos, em caixa tipo rack, com identificação conforme Apêndice V. Essa prática tem como principal objetivo evitar muitos descongelamentos e recongelamentos da alíquota positiva.

h) Identificar os microtubos de 1,5 mL com etiqueta conforme Apêndice VII;

i) Registrar a produção do lote de CQI-NAT conforme Apêndice VIII;

j) Armazenar o lote de CQI-NAT na temperatura de $80^{\circ} \mathrm{C}$ negativos, em caixa tipo rack, identificada para cada vírus alvo e limpar e organizar da área de trabalho utilizada. 


\subsection{TESTE DE HOMOGENEIDADE}

\section{OBJETIVO:}

Avaliar a homogeneidade das alíquotas do CQI-NAT, para cada vírus alvo.

\section{AMOSTRA:}

Dez amostras de CQI-NAT, para cada vírus alvo, preparadas conforme protocolo 1.4 .

\section{MATERIAIS E EQUIPAMENTOS:}

- Teste do Ácido Nucleico - NAT, conforme utilizado na rotina diária do serviço de hemoterapia;

- Agitador de tubos.

\section{PROCEDIMENTO:}

a) Paramentar-se adequadamente com os equipamentos de proteção individual;

b) Selecionar aleatoriamente, para cada vírus alvo, 10 amostras do lote de CQI-NAT produzido.

Nota: para realizar a seleção aleatória de maneira confiável, utilizar a função "aleatório entre", do Excel. As etapas abaixo e o Apêndice IX - A e B, descrevem a utilização da função para seleção dos números aleatórios.

- Listar na coluna do Excel o número 1, que corresponde à primeira amostra do lote do CQI-NAT e; o número que corresponde à última amostra do CQI-NAT do referido lote;

- Em uma célula do Excel, inserir a função abaixo:

$$
\mathrm{fx}=\mathrm{ALEATÓRIOENTRE(inferior;superior)}
$$

Equação 6: demonstração da função aleatório utilizada para seleção das amostras de CQINAT para o teste de homogeneidade.

Nota: inferior será o número 1, ou seja, a primeira alíquota do CQI-NAT e; superior será a última alíquota do CQI-NAT do lote produzido, considerando a identificação do CQI-NAT por números sequenciais, conforme proposta no Apêndice VII. 
- A cada seleção, a célula do Excel deverá ser selecionada novamente com duplo clique e, um clique em uma célula em branco para que a função possa selecionar aleatoriamente os números entre o intervalo determinado. Repetir essa etapa até obter 10 números aleatórios.

c) Separar as 10 amostras de CQI-NAT correspondente aos números selecionados aleatoriamente e descongelar a temperatura ambiente (22 a $\left.24^{\circ} \mathrm{C}\right)$;

d) Homogeneizar as 10 amostras de CQI-NAT com auxílio de um agitador de tubos;

e) Submeter as 10 amostras ao NAT, utilizado na rotina diária;

Nota: no momento da realização do NAT, identificar as duplicatas, no mapa de trabalho da rotina, correlacionando-as com a amostra de CQI-NAT de origem, conforme Apêndice X;

f) Limpar e organizar da área de trabalho utilizada.

\section{INTERPRETAÇÃO DOS RESULTADOS:}

a) Registrar os resultados obtidos, conforme Apêndice $X$ e proceder à análise estatística da homogeneidade considerando a média, o desvio padrão e coeficiente de variação entre as amostras.

Nota: para classificação da homogeneidade das amostras, foram utilizados os critérios de variação de dois $\mathrm{Ct}$, acima ou abaixo, em relação a média dos $\mathrm{Ct}$ obtidos, e o coeficiente de variação inferior a $10 \%$. 


\subsection{TESTE DE ESTABILIDADE}

\section{OBJETIVO:}

Avaliar a estabilidade das alíquotas do CQI-NAT, para cada vírus alvo, quando armazenadas em temperatura de $80^{\circ} \mathrm{C}$ negativos, durante os três primeiros dias de armazenamento.

\section{AMOSTRA:}

Três amostras de CQI-NAT, para cada vírus alvo, preparadas conforme protocolo 1.4

\section{MATERIAIS E EQUIPAMENTOS:}

- Teste do Ácido Nucleico - NAT, conforme utilizado na rotina diária do serviço de hemoterapia;

- Agitador de tubos;

- Freezer $80^{\circ} \mathrm{C}$ negativos com controle de temperatura;

\section{PROCEDIMENTO:}

a) Paramentar-se adequadamente com os equipamentos de proteção individual;

b) Selecionar aleatoriamente, seis amostras, para cada vírus alvo, do lote de CQI-NAT produzido;

c) Separar as três amostras, de CQI-NAT, para cada vírus alvo, correspondente aos números selecionados aleatoriamente.

d) Descongelar as três amostras nas mesmas condições de temperatura ambiente;

e) Selecionar uma amostra e recongelar as demais;

f) Homogeneizar as amostras de CQI-NAT com auxílio de um agitador de tubos;

g) Submeter cada amostra ao NAT, em três dias subsequentes, congelando e descongelando as amostras selecionadas para o teste;

h) Limpar e organizar da área de trabalho utilizada. 


\section{INTERPRETAÇÃO DOS RESULTADOS:}

a) Registrar os resultados obtidos, e proceder á análise estatística da estabilidade considerando a média, o desvio padrão e coeficiente de variação das réplicas, conforme Apêndice XI.

Nota: para classificação da estabilidade das amostras, foram propostos os critérios de variação de dois $\mathrm{Ct}$, acima ou abaixo, em relação à média dos $\mathrm{Ct}$ obtidos, e o coeficiente de variação inferior a $10 \%$.

Nota: recomenda-se avaliação da estabilidade com comparação dos resultados, sendo que qualquer diferença significativa dos resultados obtidos pode ser evidência de instabilidade do CQI-NAT. 


\subsection{PRODUÇÃO DO PLASMA HUMANO NEGATIVO (PHN)}

\section{OBJETIVO:}

Produção de plasma humano negativo (PHN), utilizado como diluente do CQINAT, a partir de plasma fresco congelado.

\section{AMOSTRA:}

Cinco bolsas de plasma fresco, congeladas proveniente, de doadores que tenham no mínimo duas doações nos últimos 12 meses e que apresentem resultados sorológicos negativos ou não reagentes para HIV 1 e 2, Vírus linfotrópico Humano (HTLV) 1 e 2, HCV, HBV, Sífilis e doença de Chagas, bem como NAT negativo e microbiológico negativo. Considerar a utilização de plasma que apresentem o mesmo grupo sanguíneo.

\section{MATERIAIS E EQUIPAMENTOS:}

- Pinça com trava e esterilizada;

- Tesoura esterilizada;

- Gaze estéril;

- Álcool 70\%;

- Tubos de polipropileno de fundo cônico com capacidade para $50 \mathrm{~mL}$;

- Estante suporte para tubos;

- Sacos plásticos;

- Equipo de transfusão simples com filtro;

- Homogeneizador automático para bolsas;

- Banho-maria;

- Capela de fluxo laminar;

- Equipamentos de proteção individual: luvas, jaleco descartável, óculos e máscara;

- Teste do Ácido Nucleico - NAT, conforme utilizado na rotina diária do serviço de hemoterapia;

- Freezer $20^{\circ} \mathrm{C}$ negativos, ou abaixo e com controle de temperatura;

- Equipamento de conexão estéril;

- Bolsa de transferência;

- Bolsa de drenagem com capacidade para $2.200 \mathrm{~mL}$;

- Frasco de hemocultura aeróbio;

- Agulha e seringa de $10 \mathrm{~mL}$. 


\section{PROCEDIMENTO:}

a) Selecionar cinco bolsas de plasma fresco congelado que tenham sido coletadas no dia, provenientes de doadores com no mínimo duas doações nos últimos 12 meses e resultados negativos ou não reagentes para todos os testes sorológicos e NAT. Registrar as bolsas selecionadas conforme Apêndice XII;

b) Paramentar-se adequadamente com os equipamentos de proteção individual;

c) Proceder à realização do NAT individual nas bolsas selecionadas para compor o lote de PHN;

d) Retirar as bolsas do freezer e dispor cada uma das bolsas em sacos plásticos transparentes;

e) Levar as bolsas para o banho-maria e deixar descongelar completamente à temperatura de $37^{\circ} \mathrm{C}$;

f) Registrar o tempo e a temperatura de descongelamento das bolsas, conforme Apêndice III;

Nota: deve-se ter cuidado no descongelamento para que a bolsa não rasgue e não haja derramamento de plasma no banho-maria.

g) Limpar a capela de fluxo laminar com gaze estéril e álcool $70 \%$ por 3 vezes, aguardando o tempo de evaporação do álcool $70 \%$ antes da limpar novamente as superfícies;

h) Colocar o frasco de hemocultura aeróbio na capela de fluxo laminar, ligar a luz ultravioleta por 20 minutos e registrar em planilha própria, conforme Apêndice IV;

i) Utilizar o equipamento de conexão estéril para acoplar o equipo de transfusão simples com filtro à extremidade pontiaguda de uma bolsa de transferência, de modo a obter duas extremidades pontiagudas acopladas ao equipo de transfusão;

Nota: para proceder à mistura das bolsas de plasma negativo, sem interferência no resultado final, pode-se utilizar como método alternativo um frasco do tipo Erlenmeyer, limpo e esterilizado, para mistura das bolsas negativas e, posterior aliquotagem com pipeta graduada. Porém, com este método, há impossibilidade de filtrar o plasma e poderá ocorrer a formação de bolhas no plasma durante a mistura. 
j) Limpar o lacre de inserção lateral da bolsa de plasma fresco com gaze estéril e álcool 70\%;

k) Romper o lacre de inserção lateral da bolsa de plasma fresco e conectar a ponta do equipo de transfusão simples (extremidade próxima ao filtro);

I) Filtrar as bolsas de plasma fresco para a bolsa de drenagem com capacidade para $2.200 \mathrm{~mL}$;

Nota: o limite máximo de cinco bolsas de plasma fresco deve ser respeitado para que o volume final não exceda $2.200 \mathrm{~mL}$ e o filtro do equipo não fique saturado com fibrina.

m)Proceder com as etapas $J$ a $L$ até a finalização da filtragem de todas as bolsas de plasma fresco selecionadas;

n) Homogeneizar, por inversão, ou com auxilio de um homogeneizador automático, a bolsa de drenagem por cinco minutos;

o) Coletar com seringa e agulha, $10 \mathrm{~mL}$ de plasma da bolsa de drenagem e inocular no frasco de hemocultura para realização do teste microbiológico;

p) Dispor os tubos de fundo cônico de $50 \mathrm{~mL}$ na estante de tubos;

q) Cortar a extensão do equipo com tesoura esterilizada, de modo que a extremidade da extensão que contenha o filtro seja descartada;

r) Aliquotar $45 \mathrm{~mL}$ do PHN em cada tubo de polipropileno de fundo cônico, com auxilio de uma pinça com trava e esterilizada;

s) Identificar os tubos do lote de PHN produzido, conforme Apêndice XIII e armazenar a temperatura de $20^{\circ} \mathrm{C}$ negativos, ou abaixo, com validade de até seis meses para uso. Os frascos do lote de PNH que não foram utilizados dentro do prazo de validade devem ser descartados;

Nota: depois de descongelado, o plasma pode ser mantido em temperatura de 2 a $6^{\circ} \mathrm{C}$, não devendo ser utilizado caso apresente fibrina ou turbidez.

t) Limpar e organizar da área de trabalho utilizada.

\section{INTERPRETAÇÃO DOS RESULTADOS:}

a) Após a inoculação no tubo de hemocultura dos $10 \mathrm{~mL}$ do lote de PHN preparado, o frasco deve ser mantido em cultura por sete dias para verificar o crescimento de contaminantes como bactérias ou fungos que podem ter contaminado o lote, durante o preparo; 
b) Para uso do PHN como diluente, deve-se aguardar o resultado do teste microbiológico;

c) Caso o resultado do teste microbiológico seja negativo após sete dias de cultura, o lote é liberado para uso na rotina;

d) Se o resultado do teste microbiológico apresentar positividade, um novo frasco de hemocultura deve ser inoculado com $10 \mathrm{~mL}$ da amostra de PHN do lote já preparado e, sendo esse último também positivo, o lote de PHN deve ser descartado.

Nota: um tubo de PHN de $50 \mathrm{~mL}$ pode ser armazenado em temperatura de $2^{\circ} \mathrm{C}$ a $4^{\circ} \mathrm{C}$ durante uma semana, ou até que se observe turbidez ou formação de fibrina, devendo ser descartado posteriormente. 


\subsection{ANÁLISE ESTATÍSTICA COMPLEMENTAR PARA DEFINIÇÃO DOS LIMITES DE ACEITAÇÃO DO CQI-NAT NA ROTINA}

\section{OBJETIVO:}

Definir os limites superior e inferior para aceitação dos resultados do CQI-NAT na rotina de testes.

\section{AMOSTRA:}

Resultado, em $\mathrm{Ct}$, das 20 réplicas do CQI-NAT durante seu processo de validação.

\section{MATERIAIS E EQUIPAMENTOS:}

- Computador com acesso à internet

- Resultado expresso em Ct das 20 réplicas do CQI-NAT

\section{PROCEDIMENTO:}

\section{Instalação do software $\mathbf{R}$}

a) Acessar a página eletrônica http://www.r-project.org/;

b) Selecionar a opção "download R", conforme indicado abaixo:

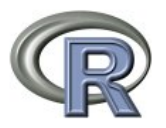

[Home]

Download

CRAN

R Project

About R

Contributors

What's New?

Mailing Lists

Bug Tracking

Conferences

Search

R Foundation

Foundation

Board

Members

Donors

Donate

\section{The R Project for Statistical Computing}

\section{Getting Started}

$R$ is a free software environment for statistical computing and aranhics. It compiles and runs on a wide variety of UNIX platforms, Windows and MacOS. To download R, please choose your preferred CRAN mirror

If you have questions about $\mathrm{R}$ like how to download and install the software, or what the license terms are, please read our answers to frequently asked questions before you send an email.

News

- R 3.2.0 (Full of Ingredients) prerelease versions will appear starting March 19. Final release is scheduled for 2015-04-16

- R version 3.1.3 (Smooth Sidewalk) has been released on 2015-03-09

- The $R$ Journal Volume $6 / 2$ is available.

- $\mathbf{R}$ version 3.1.2 (Pumpkin Helmet) has been released on 2014-10-31

- useR! 2015, will take place at the University of Aalborg, Denmark, June 30 - July 3, 2015.

- useR! 2014, took place at the University of California, Los Angeles, USA June 30 - July 3, 2014 
c) Selecionar uma plataforma de download de um endereço eletrônico proveniente do Brasil, conforme indicado abaixo:

CRAN Mirrors

The Comprehensive R Archive Network is available at the following URLs, please choose a location close to you. Some statistics on the status of the mirrors can be found $\mathrm{t}$ release.

0-Cloud

http://cran.rstudio.com

Rstudio, automatic redirection to servers worldwide

http://cran.usthb.dz

Argentina

http://mirror.fcaglp.unlp.edu.ar/CRAN/

University of Science and Technology Houari Boumediene

Australia

http://cran.csiro.au/

http://cran ms unimelb edu aut

Austria

http://cran.at. I-project.org

Belgium

http://www. freestatistics.org/cran

Brazil

http://nbcgib.uesc.br/mirrors/cran

http://cran-r.c3sl.ufpr.br/

http://cran.fiocruz.br/

http://www.vps.fmvz.usp.br/CRAI

http://brieger.esalq.usp.br/CRAN/

http://cran.stat.sfu.ca

http://mirror.its.dal.ca/cran

http://cran. utstat. utoronto.ca

http://cran skazkaforyou com

Chile

ittp://cran parentingamerica.com

China

http://dirichlet.mat.puc.c1/

Universidad Nacional de La Plata

CSIRO

University of Melbourn

Wirtschaftsuniversitaet Wien

K.U.Leuven Association

Center for Comp. Biol. at Universidade Estadual de Santa Cruz

Universidade Federal do Parana

Oswaldo Cruz Foundation, Rio de Janeiro

University of Sao Paulo, Sao Paulo

University of Sao Paulo, Piracicaba

Simon Fraser University, Burnaby

Dalhousie University. Halifax

University of Toronto

iWeb, Montreal

iWeb Montreal

Pontificia Universidad Catolica de Chile, Santiago

d) Selecionar a opção de download de acordo com o sistema operacional do computador, conforme indicado abaixo:

The Comprehensive $\mathrm{R}$ Archive Network

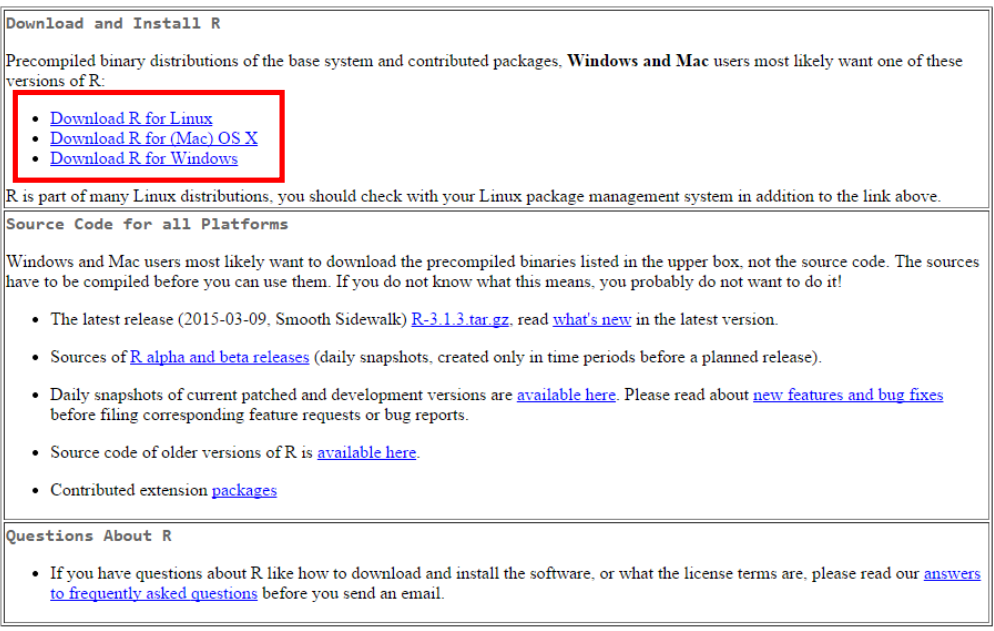

What are $\mathrm{R}$ and CRAN?

$R$ is 'GNU S', a freely available language and environment for statistical computing and graphics which provides a wide variety of statistical and graphical tech and nonlinear modelling, statistical tests, time series analysis, classification, clustering. etc. Please consult the $\mathrm{R}$ project homepage for further information CRAN is a network of ftp and web servers around the world that store identical, up-to-date, versions of code and documentation for R. Please use the CRAN mij you to minimize network load. 
e) Acessar "install $R$ for the first time", conforme indicado abaixo:

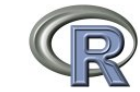

CRAN

Mirrors

What's new?

$\frac{\text { Task Vier }}{\text { Search }}$

About $R$

R Homepage

Software

R Sources

R Binarie
$\mathrm{R}$ for Windows

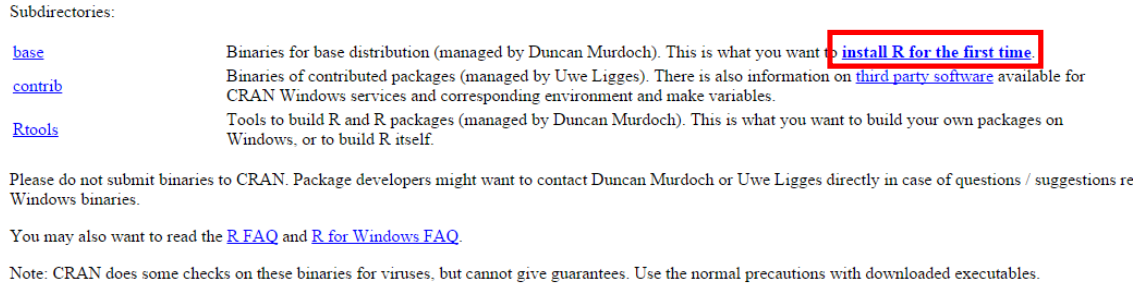

f) Acessar "download R", conforme indicado abaixo:

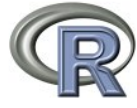

\begin{tabular}{l} 
CRAN \\
Mirrors \\
What's new? \\
$\frac{\text { Task Views }}{\text { Search }}$ \\
About $R$ \\
R Homepage \\
The R Journal \\
Software \\
R Sources \\
R Binaries \\
Packages \\
Other \\
Documentation \\
Manuals \\
\hline FAQs \\
Contributed
\end{tabular}
R-3.1.3 for Windows (32/64 bit)

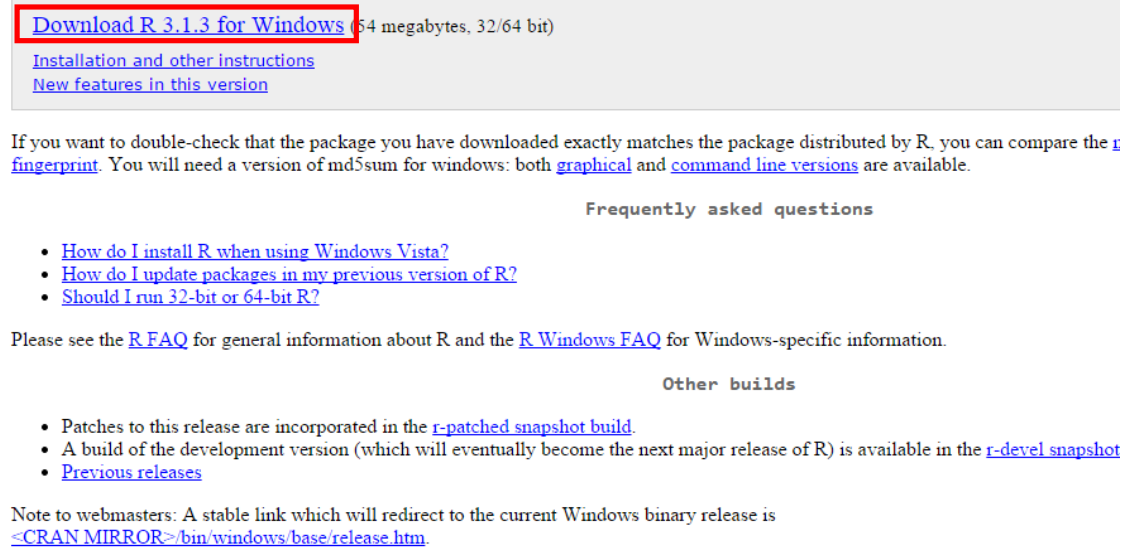

- Patches to this release are incorporated in the r-patched snapshot build.

- A build of the development version (which will eventually become the next major release of $R$ ) is available in the $\mathrm{r}$-devel snapshot - Previous releases

Note to webmasters: A stable link which will redirect to the current Windows binary release is $\leq$ CRAN MIRROR $>$ bin $/$ windows base $/$ release. $h$ tm .

g) Instalar o software no computador, depois de concluída a etapa acima.

h) Na primeira utilização do software R, escolher, na barra de tarefas superior, a opção "pacotes" e em seguida "instalar pacotes".

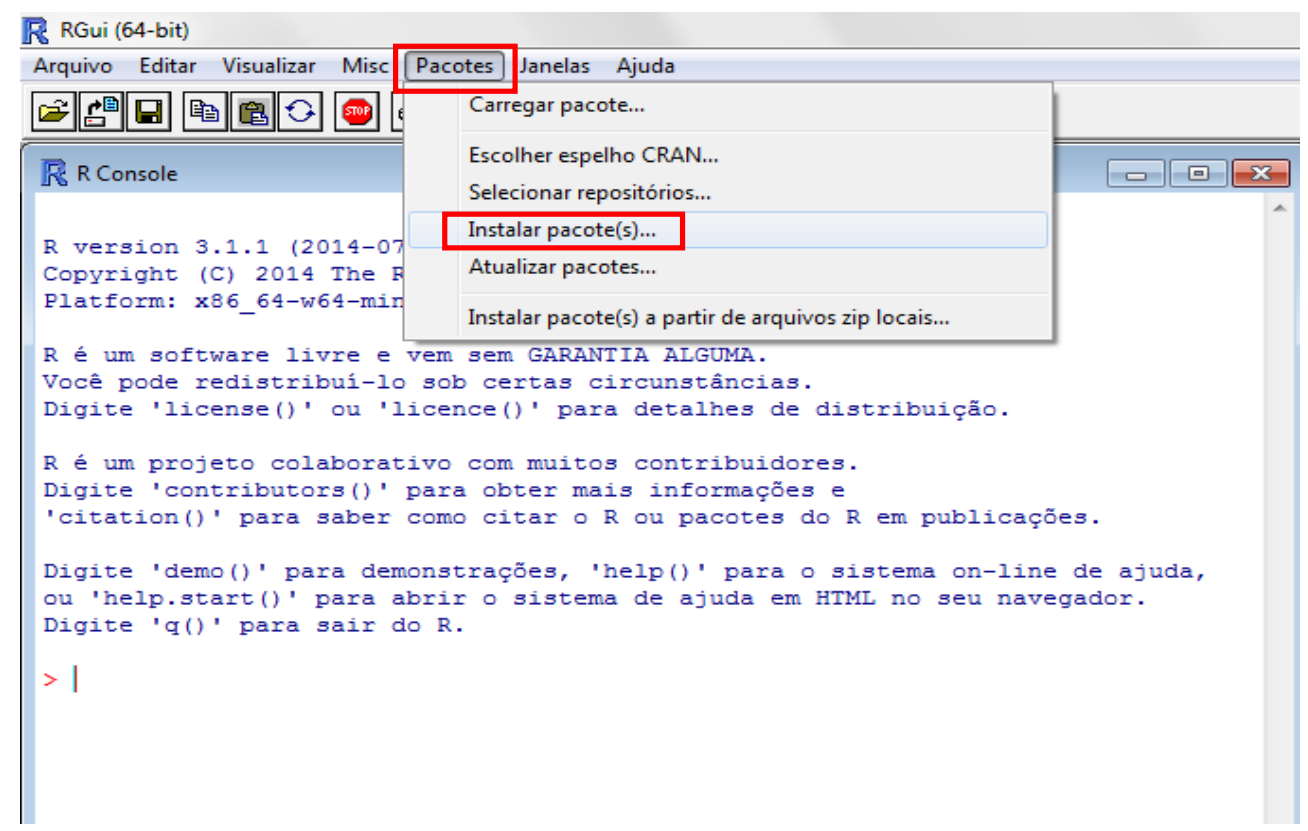


i) Selecionar um dos repositórios "CRAN mirror", por exemplo: BRAZIL (SP1) e posteriormente o comando "OK".

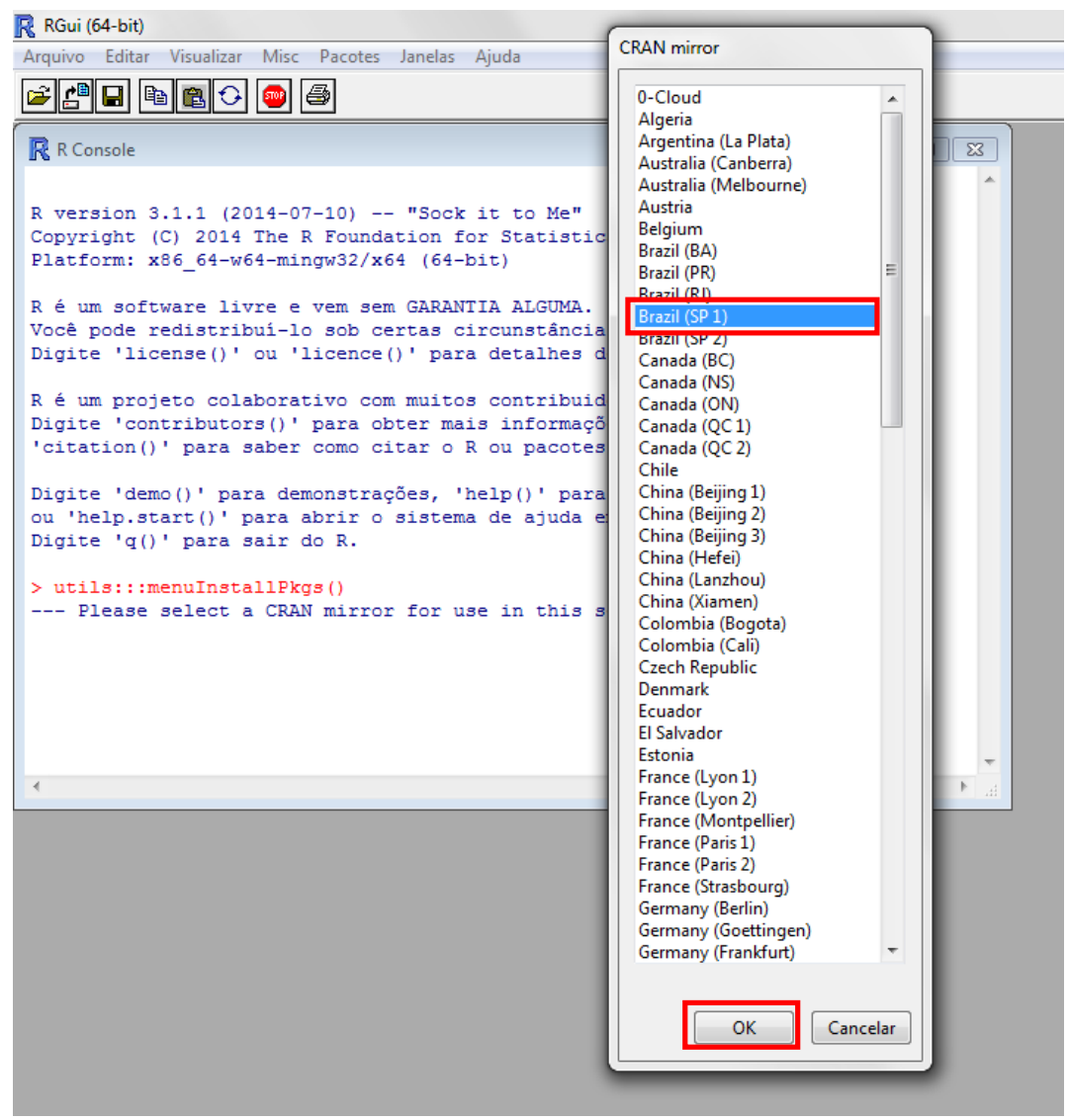

j) Selecionar na janela "packages" a biblioteca "MASS" e o comando "OK". 


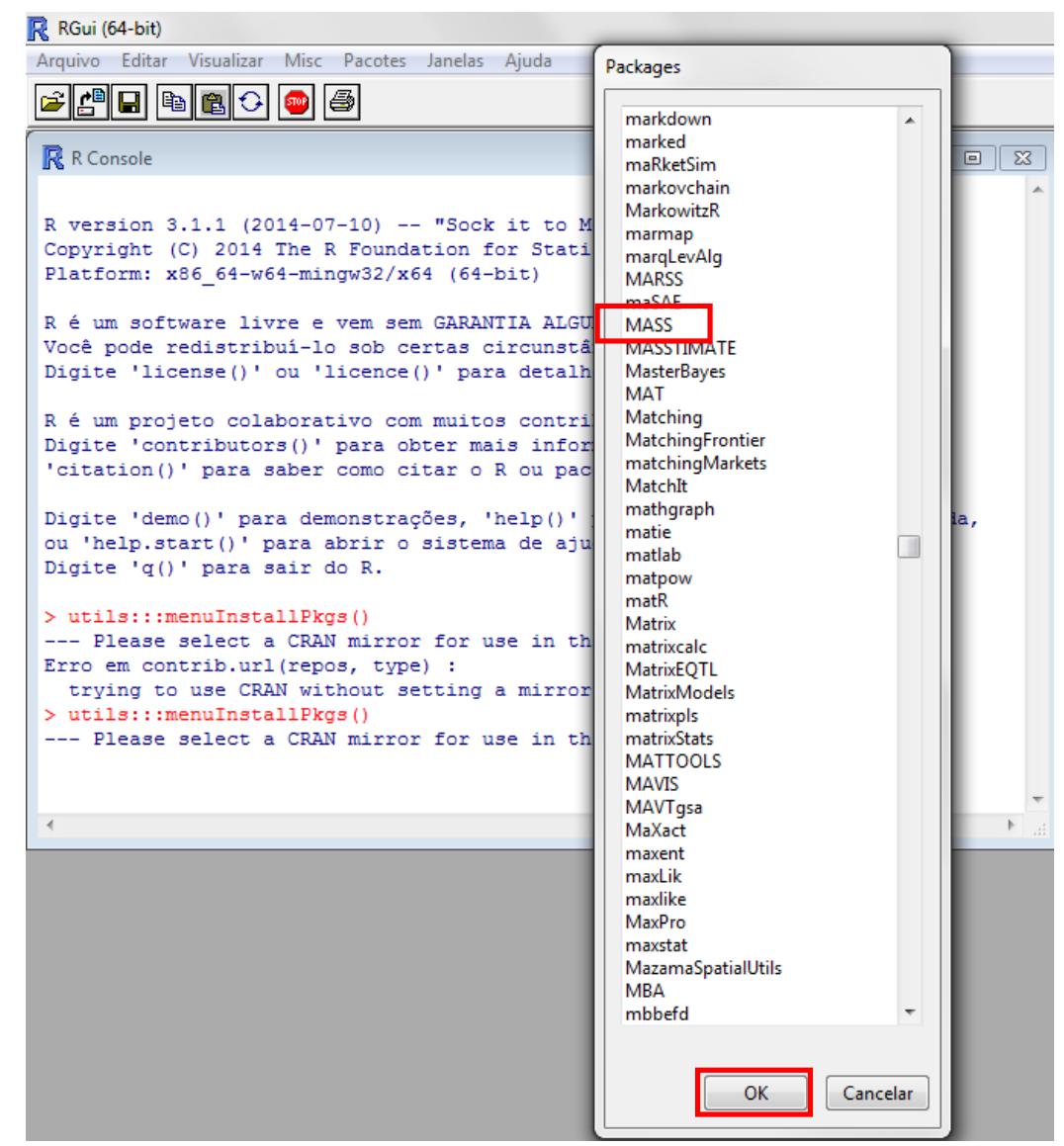

Nota: as etapas acima devem ser realizadas no primeiro acesso ao software $\mathrm{R}$ e repetidas quando necessária atualização do mesmo.

\section{Utilização do software $\mathbf{R}$}

k) Abrir o software $\mathrm{R}$ e digitar o comando

$$
\mathrm{x}<-\operatorname{scan}()
$$

em seguida, acionar Enter

I) Digitar os valores de Ct obtidos das 20 réplicas do CQI-NAT durante o processo de validação.

Nota: a tecla Enter deve ser acionada a cada digitação e também ao final de todas as digitações. 
Nota: o software $R$ não reconhece a vírgula como separação das casas decimais, devendo-se utilizar ponto para separação das casas decimais e a vírgula para separação das determinações.

m) Copiar os comandos, conforme dispostos abaixo que corresponde à fórmula estatística da curva de distribuição gama, elaborada para definição dos intervalos de referência para os limites de aceitação dos resultados do CQI-NAT na rotina.

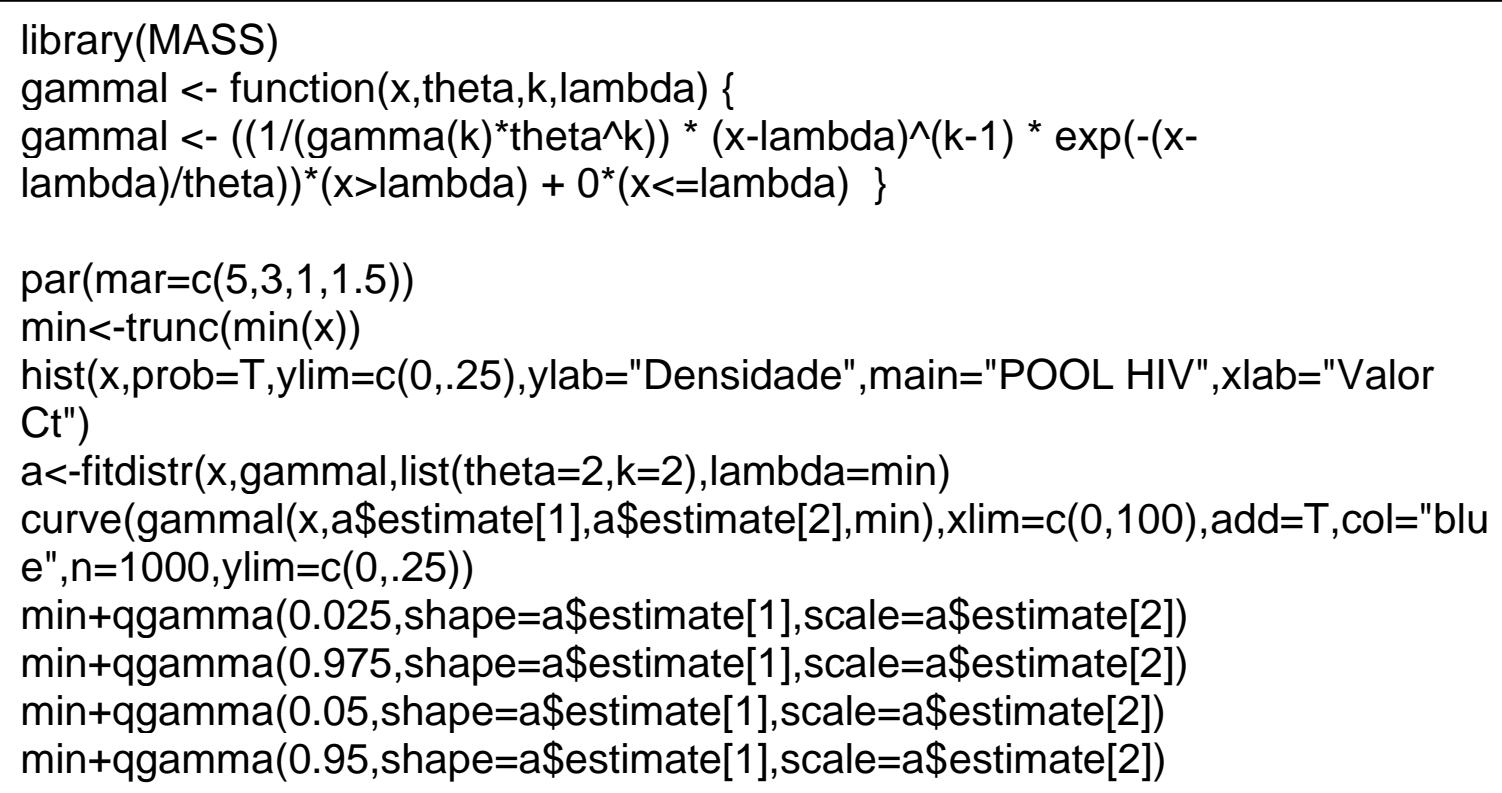

Nota: no exemplo abaixo, o limite superior foi definido com o valor de $\mathrm{Ct}$ de 34,5 e o limite inferior, com o valor de Ct de 42,6, considerando o intervalo de confiança de $95 \%$.

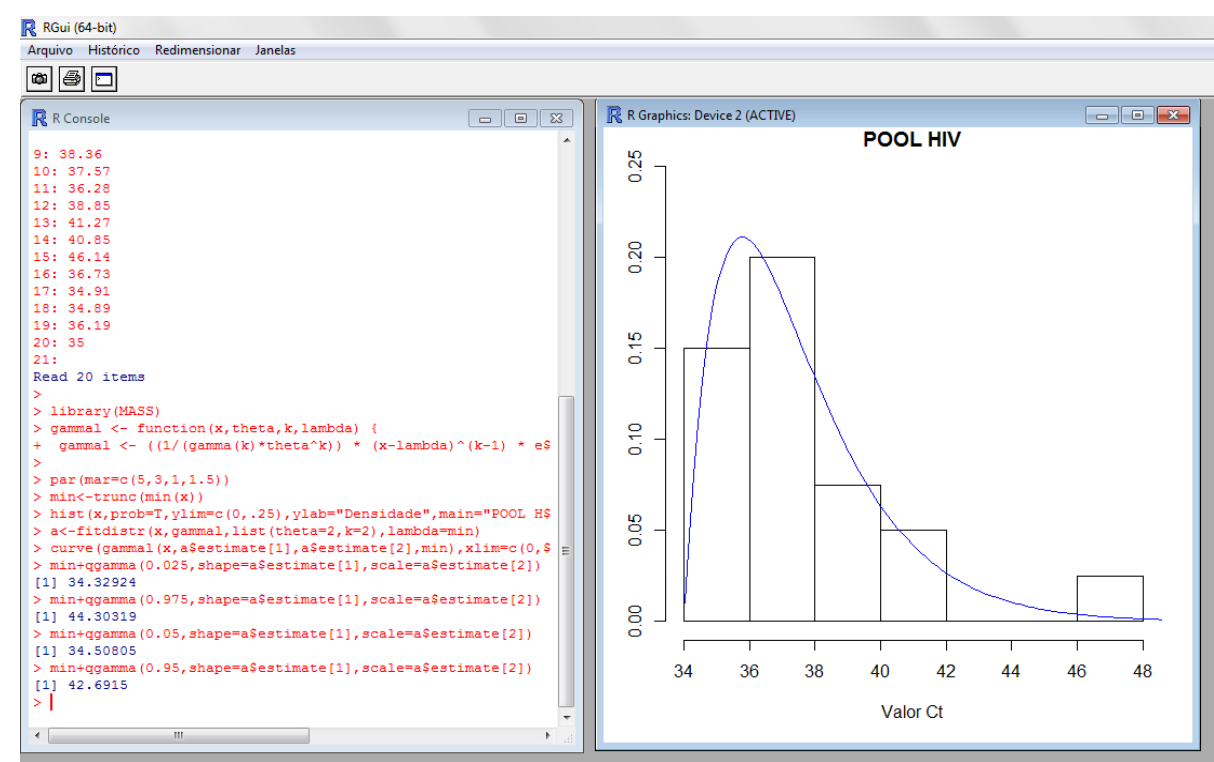


Nota: para alterar o título do gráfico de determinação deve-se substituí-lo na fórmula de maneira que todos os demais caracteres sejam preservados, alterando somente a nomenclatura, que deve ser adicionada entre aspas, conforme indicado abaixo.

\section{library(MASS)}

gammal <- function( $x$,theta,k,lambda) \{

gammal $<-\left(\left(1 /\left(\right.\right.\right.$ gamma $(\mathrm{k})^{*}$ theta $\left.\left.\mathrm{k}\right)\right){ }^{*}(\mathrm{x} \text {-lambda })^{\wedge}(\mathrm{k}-1){ }^{*} \exp (-(\mathrm{x}-$

lambda $/$ theta $))^{*}(x>$ lambda $)+0 *(x<=$ lambda $\left.)\right\}$

$\operatorname{par}(\operatorname{mar}=c(5,3,1,1.5))$

$\min <-\operatorname{trunc}(\min (x))$

hist(x,prob=T,ylim =c(0,.25),ylab="Densidade",main='POOL HIV", $x$ lab="Valor $\mathrm{Ct}$ )

a $<$-fitdistr ( $x$, gammal,list(theta $=2, k=2$ ),lambda=min)

curve(gammal (x,a\$estimate[1], a\$estimate[2], $\mathrm{min}), \mathrm{xlim}=\mathrm{c}(0,100), \mathrm{add}=\mathrm{T}, \mathrm{col}=\mathrm{b}$ blu e",n=1000,ylim $=c(0, .25))$

min+qgamma $(0.025$,shape $=a \$$ estimate[1],scale $=a \$$ estimate[2] $)$

min+qgamma $(0.975$, shape $=a \$$ estimate[1], scale $=a \$$ estimate[2] $)$

min+qgamma $(0.05$, shape $=a \$$ estimate[1],scale $=a \$$ estimate[2] $)$

min+qgamma $(0.95$, shape $=a \$ e s t i m a t e[1]$, scale $=a \$$ estimate[2] $)$

n) A partir da definição dos limites de aceitação, construir um gráfico no programa Excel de modo a registrar os resultados do CQI-NAT obtidos na rotina, permitindo seu acompanhamento. 


\subsection{PROCESSAMENTO NA ROTINA E ACOMPANHAMENTO}

\section{OBJETIVO:}

Processar o CQI-NAT em cada rotina NAT para avaliação e acompanhamento dos resultados obtidos.

\section{AMOSTRA:}

Um microtubo de CQI-NAT para cada vírus alvo e um tubo de fundo cônico de PHN produzido conforme os procedimentos descritos nesse Manual.

\section{MATERIAIS E EQUIPAMENTOS:}

- Teste do Ácido Nucleico - NAT, conforme utilizado na rotina diária do serviço de hemoterapia;

- Pipeta de $1.000 \mu \mathrm{L}$ e ponteiras descartáveis;

- Equipamentos de proteção individual: luvas, jaleco descartável, óculos e máscara;

- Gráfico controle, para cada vírus, para acompanhamento do CQI-NAT na rotina.

\section{PROCEDIMENTO:}

a) Descongelar uma amostra de CQI-NAT para cada vírus alvo;

b) Transferir, com pipeta de $1.000 \mu \mathrm{L}$ e ponteiras descartáveis, a amostra de CQI-NAT para um tubo semelhante àquele utilizado na coleta de amostras dos doadores;

c) Processar o CQI-NAT na rotina de acordo com o teste realizado no serviço de hemoterapia;

Nota: caso o teste seja realizado em pool de amostras, o CQI-NAT deve ser reproduzido da mesma forma. Assim, para composição do pool de amostras, deve-se utilizar um tubo de CQI-NAT para cada vírus alvo separadamente e o volume restante deve ser completado com PHN de preferência pipetado pelo equipamento da plataforma utilizada.

d) Se, o teste for realizado em amostras individuais, o CQI-NAT para cada vírus deve ser utilizado separadamente sem a necessidade completar 0 volume com PHN. 


\section{INTERPRETAÇÃO DOS RESULTADOS:}

a) Registrar os valores obtidos pelo CQI-NAT para cada vírus em gráficos controle separados, conforme Apêndice XIV;

b) Avaliar rotineiramente se os valores dispostos no gráfico controle encontram-se dentro dos limites definidos como aceitáveis e realizar análise crítica dos resultados obtidos.

c) Caso o valor do CQI-NAT apresentar de variação acima dos limites definidos como aceitáveis, a rotina NAT deve ser repetida.

Nota: na análise crítica dos dados do CQI-NAT, deve-se analisar a quantidade de rotinas que foram invalidas e investigar o possível motivo dessa ocorrência, propondo ações corretivas ou preventivas.

Ainda, CQI-NAT também pode ser utilizado para avaliação lote a lote, conforme preconiza a Portaria oㅡ 2.712/2013. Assim, caso apresente valores diferentes dos limites aceitáveis, deve-se avaliar a rejeição do referido lote para uso na rotina.

\section{DESVIOS:}

Cabe ressaltar que durante a produção e padronização do CQI-NAT, interferentes como o tubo utilizado para pipetagem do CQI-NAT pela plataforma de testes utilizada na rotina, o descongelamento e recongelamento das bolsas positivas e a diluição ideal selecionada para trabalho, podem ser consideradas como limitações dos protocolos desenvolvidos.

Dessa forma, o CQI-NAT é um produto aprimorado a cada rotina de produção e os resultados do seu processamento diário fora dos padrões estabelecidos devem ser observados considerando, inclusive, possíveis limitações de produção. 


\section{CAPÍTULO IV}

\section{RESULTADOS}

\subsection{Caracterização das bolsas de plasma positivas para HIV e HCV}

Foram selecionadas duas bolsas com resultados positivos tanto na triagem sorológica quanto no NAT. A bolsa positiva para HIV, como volume total de $450 \mathrm{~mL}$ e coletada em 10/09/2013, apresentou inicialmente resultado sorológico para ELISA anti-HIV de densidade óptica (DO) de 3,096 e nas repetições de 3,379 e 3,305 pelo teste HIV 1+2 Siemens, lote 42013, validade 13/11/13, para quimiluminescência, pelo teste HIV Ag/Ab Abbott, lote 23509li00, validade 30/07/14, apresentou resultado de 290,000 unidades relativas de luz (RLU) e nas repetições 292,800 RLU, 296,990 RLU, Western Blot positivo e NAT HIV/HCV Bio-Manguinhos, lote 137NT035Z, validade 01/14 detectável com valor de Ct de 25,510 individualmente.

A bolsa positiva para HCV, com volume total de $450 \mathrm{~mL}$, coletada em 30/11/2013 foi triada com teste sorológico HCV Ag/Ab Biorad, lote 3b05698, validade 30/07/14 e apresentou resultados de DO de 1,886 e, nas repetições, resultados de 1,663 e 1,647. Para o NAT HIV/HCV Bio-Manguinhos, lote 139NT045Z, validade 03/14, o resultado foi detectável, com Ct de 19,110 na amostra individual. Foram quantificadas as cargas virais de ambas as bolsas com a colaboração do Hemocentro da Unicamp e do Hospital das Clínicas da Faculdade de Medicina de Ribeirão Preto da Universidade de São Paulo, sendo que para o HIV, o valor foi de 173.360 cópias $/ \mathrm{mL} \log =5,239$ e para o HCV de $5.753 .706 \mathrm{Ul} / \mathrm{mL}$ Log=6,76 (Tabela 2). As bolsas foram segregadas e armazenadas à temperatura de $80^{\circ} \mathrm{C}$ negativos, em sacos plásticos transparentes, com etiquetas de identificação de risco biológico. 
Tabela 2: Resultados de triagem sorológica, NAT e carga viral das bolsas selecionadas para produção do CQI-NAT.

\begin{tabular}{|c|c|c|c|c|c|c|}
\hline \multirow{2}{*}{$\begin{array}{l}\text { Bolsas } \\
\text { positivas }\end{array}$} & \multicolumn{3}{|c|}{ Sorologia } & \multirow{2}{*}{\multicolumn{2}{|c|}{$\operatorname{NAT}(\mathbf{C t})$}} & \multirow{2}{*}{$\begin{array}{l}\text { Carga } \\
\text { Viral }\end{array}$} \\
\hline & ELISA (DO) & $\begin{array}{l}\text { Quimiluminescência } \\
\text { (RLU) }\end{array}$ & $\begin{array}{l}\text { Western } \\
\text { Blot }\end{array}$ & & & \\
\hline HIV & $\begin{array}{l}3,096 \\
3,379 \\
3,305\end{array}$ & $\begin{array}{l}290,000 \\
292,800 \\
296,990\end{array}$ & Positivo & Detectável & $(25.51)$ & $\begin{array}{c}173.360 \\
\text { cópias } / \mathrm{mL} \\
\text { Log=5,239 }\end{array}$ \\
\hline $\mathrm{HCV}^{*}$ & $\begin{array}{l}1,886 \\
1,663 \\
1,647\end{array}$ & - & - & Detectável & $(19,11)$ & $\begin{array}{c}5.753 .706 \\
\text { UI/MI } \\
\text { Log }=6,76\end{array}$ \\
\hline
\end{tabular}

*: na triagem sorológica para HCV não são realizados testes de quimiluminescência e Western Blot.

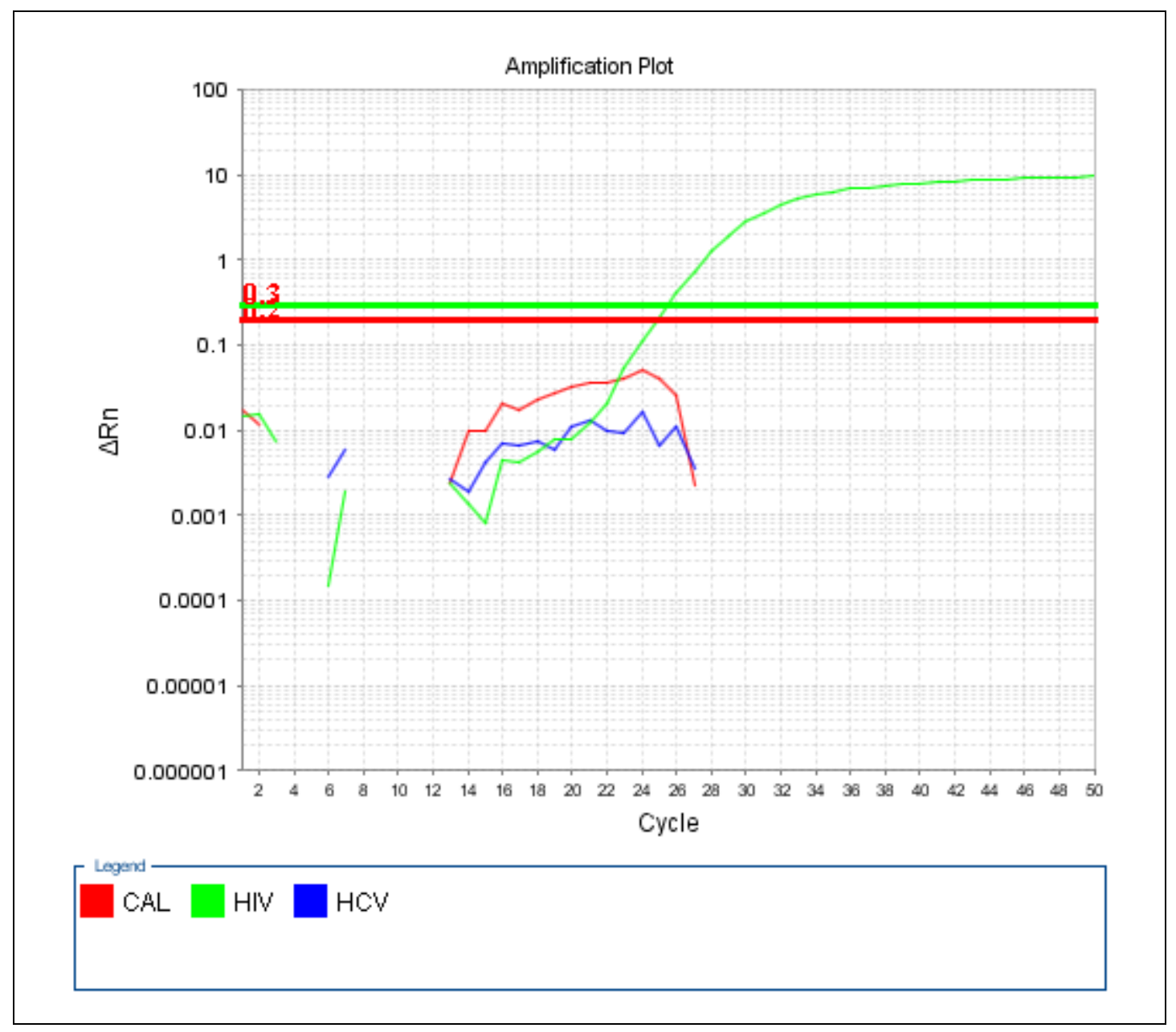

Figura 4: Curva de amplificação de amostra positiva para HIV. Este resultado NAT é referente à bolsa de plasma positivo para HIV selecionada para produção do CQI-NAT. A curva na cor verde demonstra a amplificação da amostra positiva para HIV. Na figura é possível identificar a curva da amostra positiva e a não amplificação do controle interno da reação devido (em vermelho) à positividade da amostra. 


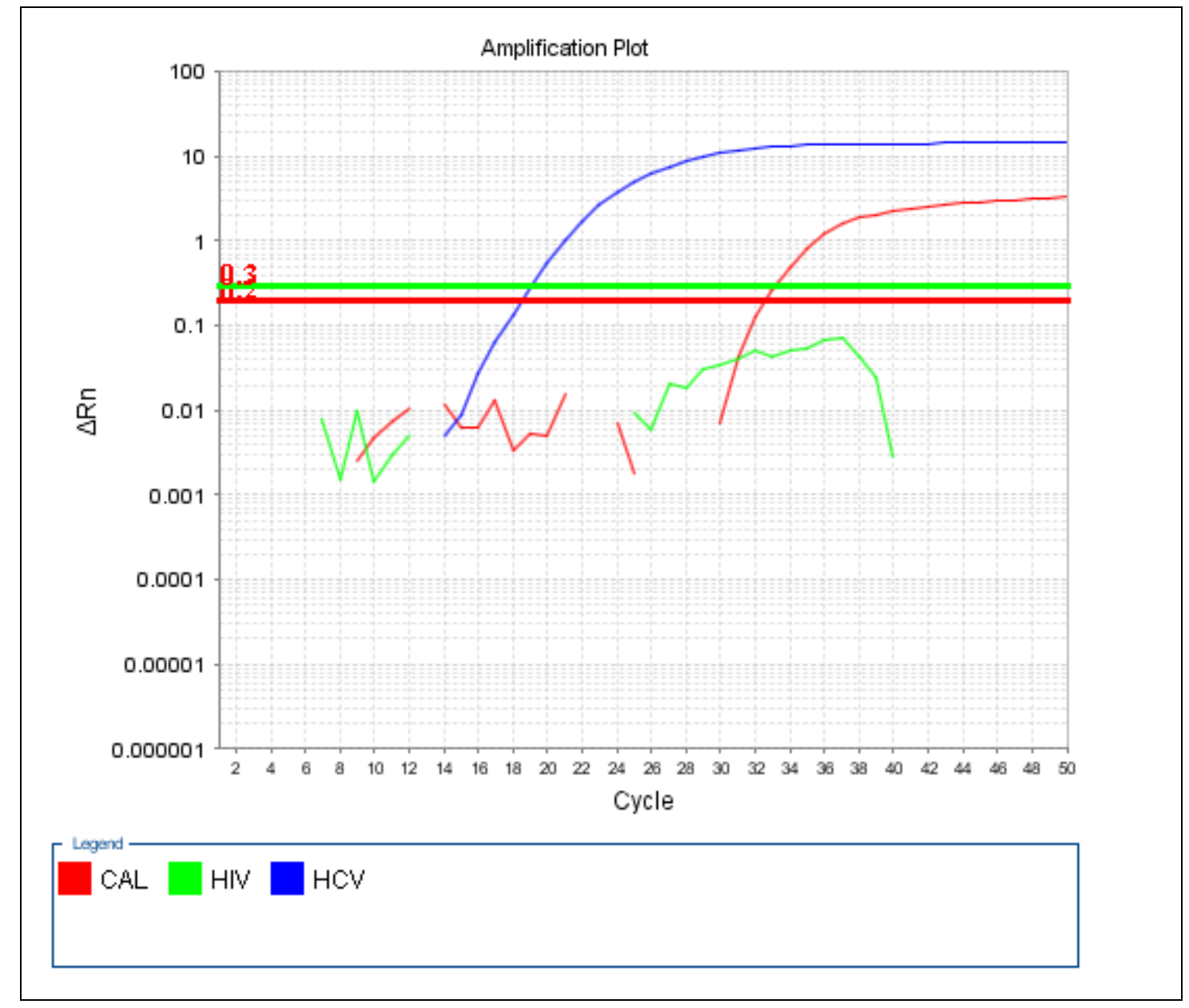

Figura 5: Curva de amplificação de amostra positiva para HCV. Na figura, observa-se a curva de amplificação da amostra positiva para HCV (em azul) selecionada para produção do CQI-NAT HCV. Na figura é possível identificar as curvas tanto da amostra positiva (em azul) quanto do controle interno da reação (em vermelho).

Antes da seleção das bolsas positivas, as amostras foram testadas individualmente no NAT HIV/HCV Bio-Manguinhos, em replicatas para confirmação da positividade, bem como avaliar a reprodutibilidade dos resultados. No momento de uso, as bolsas foram descongeladas em banho-maria à temperatura de $37^{\circ} \mathrm{C} \mathrm{e}$ aliquotadas individualmente, dentro da capela de fluxo laminar, em tubos de polipropileno de $45 \mathrm{~mL}$, de modo que antes da aliquotagem, cada bolsa positiva foi homogeneizada durante 10 minutos.

Com a finalidade de encontrar a diluição ideal da amostra a ser utilizada no CQINAT, a partir da alíquota de $45 \mathrm{~mL}$, foi realizada curva de diluição seriada, considerando como pontos de diluição 1:2 até 1:1024, com solução inicial para HIV de 
$625 \mu \mathrm{L}$ da amostra positiva e 39,375 mL de PHN e para HCV, 39,687 mL PHN e 313 uL bolsa positiva. Para cada ponto da curva, foi realizado o NAT HIV/HCV BioManguinhos em pool e individualmente, ambas as determinações em duplicata.

Após avaliação dos resultados obtidos na curva de diluição, foram selecionadas para utilização no CQI-NAT as diluições trabalho de 1:64 para HIV e 1:128 para HCV, uma vez que estas foram o maior fator de diluição no qual foi observada a amplificação das duas réplicas com valores de Ct homogêneos. Para avaliação da reprodutibilidade dessas diluições, foi realizado NAT HIV/HCV BioManguinhos, lote 143 NT007Z de 20 réplicas processadas em pool de seis amostras: uma diluição positiva para HIV, uma diluição positiva para HCV e quatro amostras de PHN. A partir dos dados de Ct, tanto dos pools quanto dos controles internos da reação, obtidos em cada uma das duas plataformas NAT do Hemocentro de Ribeirão Preto, foram calculados os valores de média $(\bar{X})$, desvio padrão $(S)$ e coeficiente de variação $(\mathrm{CV})$ entre as amostras processadas (Tabela 3 ) para avaliação da reprodutibilidade da diluição selecionada e posterior confecção do CQI-NAT. 
Tabela 3: Resultados de processamento das 20 réplicas da diluição selecionada para uso na confecção do CQI-NAT, processadas em pool de seis amostras.

\begin{tabular}{|c|c|c|c|c|c|c|}
\hline & \multicolumn{3}{|c|}{ Plataforma 1 - processamento pool } & \multicolumn{3}{|c|}{ Plataforma 2 - processamento pool } \\
\hline & $\begin{array}{c}\text { HIV - 1:64 } \\
\text { Valor Ct }\end{array}$ & $\begin{array}{c}\text { Controle interno } \\
\text { Valor Ct }\end{array}$ & $\begin{array}{c}\text { HCV - 1:128 } \\
\text { Valor Ct }\end{array}$ & $\begin{array}{c}\text { HIV - 1:64 } \\
\text { Valor Ct }\end{array}$ & $\begin{array}{c}\text { Controle interno } \\
\text { Valor Ct }\end{array}$ & $\begin{array}{c}\text { HCV - 1:128 } \\
\text { Valor Ct }\end{array}$ \\
\hline & 37,86 & 33,42 & 32,95 & 35,69 & 34,86 & 29,84 \\
\hline & 36,27 & 33,99 & 34,01 & 35,32 & 35,46 & 30,13 \\
\hline & 35,97 & 33,59 & 32,76 & 35,49 & 34,79 & 30,44 \\
\hline & 35,3 & 32,3 & 33,11 & 37,00 & 33,75 & 30,09 \\
\hline & 36,19 & 32,68 & 32,55 & 35,74 & 33,83 & 30,53 \\
\hline & 34,29 & 32,49 & 29,43 & 35,37 & 34,15 & 30,35 \\
\hline & 34,39 & 32,48 & 29,58 & 35,54 & 33,6 & 31,02 \\
\hline & 34,68 & 33,09 & 29,75 & 35,6 & 33,39 & 30,35 \\
\hline & 40,82 & ${ }^{*} \mathrm{ND}$ & 30,03 & 35,76 & 34,58 & 30,11 \\
\hline & 34,26 & 35,33 & 29,7 & 37,3 & 34,59 & 30,76 \\
\hline & 35,65 & 32,67 & 29,45 & 35,74 & 34,49 & 30,08 \\
\hline & 33,98 & 33,09 & 29,53 & 37,56 & 33,95 & 29,55 \\
\hline & 34,16 & 32,47 & 29,37 & 36,11 & 33,45 & 29,78 \\
\hline & 35,74 & 32,68 & 30,06 & 38,71 & 33,11 & 29,91 \\
\hline & 42,1 & 31,63 & 33,19 & 36,59 & 33,28 & 30,95 \\
\hline & 37,31 & 32,96 & 33,35 & 37,84 & 34,3 & 30,63 \\
\hline & 34,3 & 33,29 & 29,51 & 37,33 & 33,42 & 29,79 \\
\hline & 35,23 & 32,45 & 29,58 & 40,23 & 34,16 & 33,92 \\
\hline & 33,99 & 34,21 & 29,83 & ${ }^{*} \mathrm{ND}$ & 33,45 & 34,28 \\
\hline & 34,95 & 34,01 & 30,38 & 37,5 & 32,59 & 33,73 \\
\hline Média & 35,87 & 33,10 & 30,91 & 36,61 & 33,96 & 30,81 \\
\hline${ }^{* \star D P}$ & 2,150 & 0,832 & 1,669 & 1,313 & 0,685 & 1,386 \\
\hline${ }^{* \star *} \mathrm{CV}$ & $6,0 \%$ & $2,5 \%$ & $5,4 \%$ & $3,6 \%$ & $2,0 \%$ & $4,5 \%$ \\
\hline
\end{tabular}

o teste NAT em pool de seis amostras com o objetivo de avaliar a reprodutibilidade das diluições de 1:64 para HIV e 1:128 para HCV, selecionadas para produção 
do CQI-NAT. *ND: não detectável. Na plataforma 1, para HIV a média foi de 35,87, o desvio padrão de 2,150 e o coeficiente de variação de 6,0\% e para HCV, a média foi de 30,91 , o desvio padrão de 1,669 e coeficiente de variação de $5,4 \%$. Na plataforma 2, para HIV, os valores de média, desvio padrão e coeficiente de variação foram 36,61, 1,313 e 3,6\% e, para HCV 30,81, 1,386 e 4,5\% respectivamente. **DP: desvio padrão; ***CV: coeficiente de variação. 
Posteriormente, as amostras do CQI-NAT para uso na rotina foram preparadas, conforme a diluição de 1:64 para HIV e 1:128 para o HCV, utilizando como diluente $\mathrm{PHN}$, homogeneizadas por 10 minutos e aliquotadas em microtubo de 1,5 mL. Após o preparo, o lote de CQI-NAT produzido foi armazenado a $80^{\circ} \mathrm{C}$ negativos.

Para definição dos limites superiores e inferiores do gráfico controle para acompanhamento do CQI-NAT na rotina, foram analisados estatisticamente os dados do processamento das 20 réplicas da diluição ideal de trabalho no software de domínio público R, disponível em (http://www.r-project.org/). Considerando que os resultados obtidos dos valeres de Ct não apresentam uma distribuição normal, foi proposta curva de distribuição gama a partir da função densidade de probabilidade $f(x)$ de uma variável aleatória ${ }^{X}$. Essa função foi incluída no software $\mathrm{R}$ que, juntamente com os dados das 20 determinações, resultou na definição do intervalo de referência para o gráfico controle.

\subsection{Teste de Homogeneidade e estabilidade}

Foram selecionadas aleatoriamente 10 alíquotas do lote de CQI-NAT, para cada vírus alvo, e estas foram submetidas individualmente ao NAT HIV/HCV BioManguinhos para avaliação da homogeneidade, obtendo os resultados de coeficiente de variação de 0,81\%, entre as amostras de CQI-NAT HCV e de $1,31 \%$ entre as amostras de CQI-NAT HIV (Tabela 4). Também, foi realizado teste de estabilidade (Tabela 5), durante os três primeiros dias de armazenamento e antes da utilização do CQI-NAT na rotina, sendo avaliada a temperatura de armazenamento de $80^{\circ} \mathrm{C}$ negativos para três amostras, selecionadas aleatoriamente, mantidas sob as mesmas condições de congelamento e descongelamento durante os três dias consecutivos. Para o teste de estabilidade, foi avaliado o resultado do coeficiente de variação entre os três dias consecutivos de processamento das amostras individualmente no NAT, sendo que para HCV, o resultado foi de $1,78 \%$ e para HCV de $0,58 \%$. Como critério de aceitação da homogeneidade e estabilidade das amostras foi utilizada a variação 
de dois $\mathrm{Ct}$, acima ou abaixo, em relação à média dos $\mathrm{Ct}$ obtidos, com coeficiente de variação inferior a $10 \%$.

Tabela 4: Resultado do teste de homogeneidade para o lote de CQI-NAT.

\begin{tabular}{|c|c|c|c|}
\hline \multicolumn{4}{|c|}{ Teste Homogeneidade* } \\
\hline $\begin{array}{c}\text { Amostra } \\
\text { CQI-NAT HCV }\end{array}$ & Ct & $\begin{array}{c}\text { Amostra } \\
\text { CQI-NAT HIV }\end{array}$ & Ct \\
\hline 1 & 26,76 & 1 & 33,08 \\
\hline 2 & 26,76 & 2 & 32,82 \\
\hline 3 & 26,69 & 3 & 33 \\
\hline 4 & 26,8 & 4 & 31,89 \\
\hline 5 & 26,65 & 5 & 32,57 \\
\hline 6 & 26,76 & 6 & 33,5 \\
\hline 7 & 26,83 & 7 & 32,96 \\
\hline 8 & 26,98 & 8 & 32,52 \\
\hline 9 & 27,09 & 9 & 32,69 \\
\hline 10 & 27,36 & 10 & 32,56 \\
\hline Média & 26,87 & Média & 32,76 \\
\hline Desvio padrão & 0,22 & Desvio padrão & 0,43 \\
\hline $\begin{array}{l}\text { Coeficiente de } \\
\text { variação (\%) }\end{array}$ & 0,81 & $\begin{array}{l}\text { Coeficiente de } \\
\text { variação (\%) }\end{array}$ & 1,31 \\
\hline
\end{tabular}

Tabela 5: Resultado do teste de estabilidade para o lote de CQI-NAT.

\begin{tabular}{|c|c|c|}
\hline \multicolumn{3}{|c|}{ Teste Estabilidade $^{\star}$} \\
\hline Dias & $\mathrm{HCV}$ & HIV \\
\hline 1 & 27,46 & 32,95 \\
\hline 2 & 27,71 & 33,07 \\
\hline 3 & 26,58 & 32,62 \\
\hline Média & 27,25 & 32,88 \\
\hline Desvio padrão & 0,48 & 0,19 \\
\hline $\begin{array}{c}\text { Coeficiente de variação } \\
(\%)\end{array}$ & 1,78 & 0,58 \\
\hline $\begin{array}{l}\text { *O teste de estabilidade real } \\
\text { CQI-NAT durante três di } \\
\text { mesmas condições de } \\
\text { negativos, descongelament } \\
\text { resultados de coeficiente } \\
0,58 \% \text { e para HCV de } \\
\text { estabilidade durante os dias }\end{array}$ & $\begin{array}{l}\text { conas } \\
\text { conse } \\
\text { nazenaı } \\
\text { e reco } \\
\text { variaçã } \\
1,78 \% \text {, } \\
\text { aliados. }\end{array}$ & $\begin{array}{l}\text { tras do lote } \\
\text { s sob as } \\
\text { a } 80^{\circ} \mathrm{C} \\
\text { mento. Os } \\
\text { ra HIV foi } \\
\text { ando boa }\end{array}$ \\
\hline
\end{tabular}




\subsection{Produção do plasma humano negativo}

O plasma humano negativo ( $\mathrm{PHN}$ ), utilizado como diluente do painel foi produzido a partir de cinco bolsas de plasma fresco congelado proveniente de doadores com no mínimo duas doações nos últimos 12 meses e que apresentaram resultados sorológicos negativos ou não reagentes para HIV 1 e 2, Vírus linfotrópico Humano (HTLV) 1 e 2, HCV, HBV, sífilis e doença de Chagas, bem como NAT negativo e microbiológico negativo. Essas bolsas foram segregadas, descongeladas em banho-maria e limpas com gaze e álcool $70 \%$. Posteriormente, todas foram filtradas e misturadas em uma única bolsa de drenagem com capacidade para 2.200 $\mathrm{mL}$ com auxílio de equipo de transfusão simples com filtro, acoplado por conexão estéril à extremidade pontiaguda de uma bolsa de transferência, de modo a obter duas extremidades pontiagudas acopladas ao equipo de transfusão. Após mistura e homogeneização, $10 \mathrm{~mL}$ de plasma da bolsa de drenagem foram inoculados no frasco de hemocultura para realização de teste microbiológico, que depois de sete dias de incubação apresentou resultado negativo. Todo conteúdo da bolsa de drenagem foi distribuído tubos de polipropileno de fundo cônico em alíquotas de $45 \mathrm{~mL}$ e, essas armazenadas na temperatura de $20^{\circ} \mathrm{C}$ negativos.

\subsection{Definição dos limites do gráfico controle para acompanhamento do CQI- NAT na rotina NAT}

Para definição dos limites do gráfico e do intervalo de referência representativo dos resultados do CQI-NAT na rotina, foi proposta a utilização da curva de distribuição gama, considerando que, após análise estatística dos dados de Ct das amostras NAT, foi evidenciado que estes não seguem uma distribuição normal.

A função densidade de probabilidade $f(x)$ de uma variável aleatória $X$, que segue uma distribuição normal (Equação 7), é uma função em que os valores da variável pertencem a todo o espaço dos números reais. 


$$
f(x)=\frac{1}{\sigma \sqrt{2 \pi}} \exp \left(-\frac{(x-\mu)^{2}}{2 \sigma^{2}}\right) I_{(-\infty, \infty)}(x),
$$

Equação 7: função densidade de probabilidade com distribuição normal. ${ }^{X}$ é a variável aleatória; ${ }^{\mu} \mathrm{e}$ $\sigma$ são respectivamente a média e o desvio padrão populacional de ${ }^{X} ; \pi$ é a constante $3,14159 \ldots$, e $I_{(-\infty, \infty)}(x)$ é uma função indicadora que informa que os valores da variável podem assumir pertencem a todo o espaço dos números reais.

Assim, o gráfico da função $f(x)$ é uma curva simétrica em torno da média $\mu$, conhecida como curva normal. Uma propriedade desta curva é que no intervalo entre $\mu-2 \sigma \mathrm{e}^{\mu+2 \sigma}$, temos uma área que ocupa aproximadamente $95 \%$ de seu total (Figura 6).

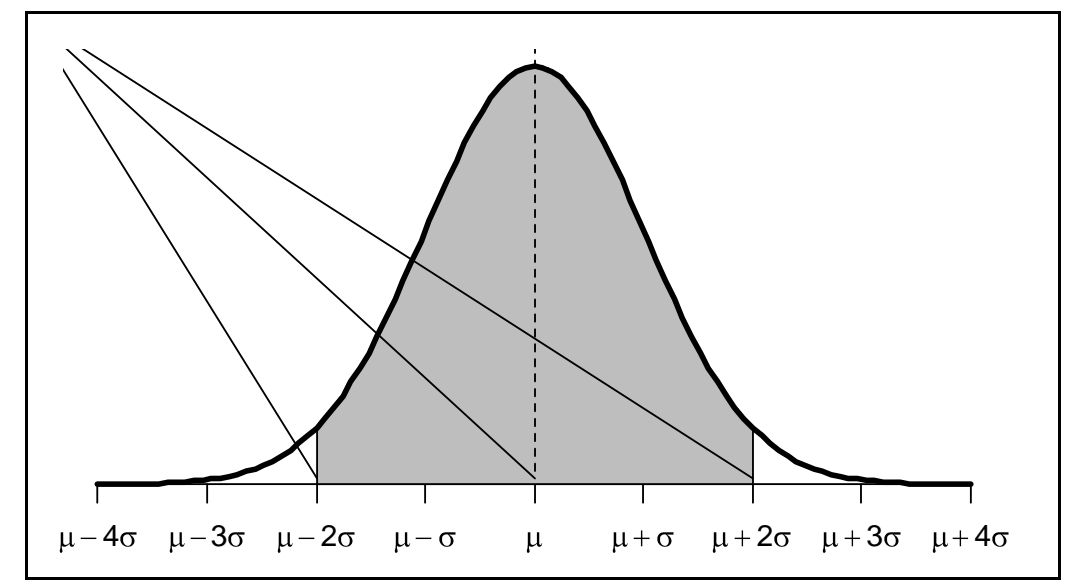

Figura 6: Curva normal em torno da média. A área sombreada corresponde a aproximadamente $95 \%$ da área sob toda a extensão da curva, ou seja, cerca de $95 \%$ dos valores populacionais da variável encontram-se dentro deste intervalo e, quase a totalidade das observações populacionais da variável estão representadas entre ${ }^{\mu-3 \sigma} \mathrm{e}^{\mu+3 \sigma}$.

A curva normal é bastante utilizada na área da saúde para a obtenção de regiões de referência (ou normalidade) para diversas variáveis de interesse. Porém, essa curva somente é válida quando a distribuição da variável de interesse é simétrica, ou pode aproximar-se de uma curva simétrica com o uso de logaritmos.

Entretanto, os valores de Ct para CQI-NAT analisado neste trabalho seguem uma determinada distribuição assimétrica, assim, como alternativa para a geração dos limites superior e inferior do gráfico de controle, foi proposto o uso da distribuição 
gama (Equação 8), em que os parâmetros $k$ e $\theta$ foram estimados pelo método da máxima verossimilhança (Choi e Wette, 1969).

$$
f(x)=\frac{1}{\Gamma(k) \theta^{k}} x^{k-1} \exp \left(-\frac{x}{\theta}\right) I_{(0, \infty)}(x),
$$

Equação 8: função densidade de probabilidade $f(x)$ de uma variável aleatória ${ }^{X}$ que segue uma distribuição gama. $k>0$, parâmetro de forma, $\theta>0$, parâmetro de escala e ${ }^{I_{(A)}(x)}$ é uma função indicadora que assume $1 \mathrm{se}^{x}$ pertence ao conjunto ${ }^{A}$ e zero caso contrário. A média da variável ${ }^{X}$ é dada por $E(X)=k \theta$ e a variância é dada por $\operatorname{Var}(X)=k \theta^{2}$.

A curva gama representa uma variável que sempre assume valores maiores que zero, e sua distribuição é assimétrica.

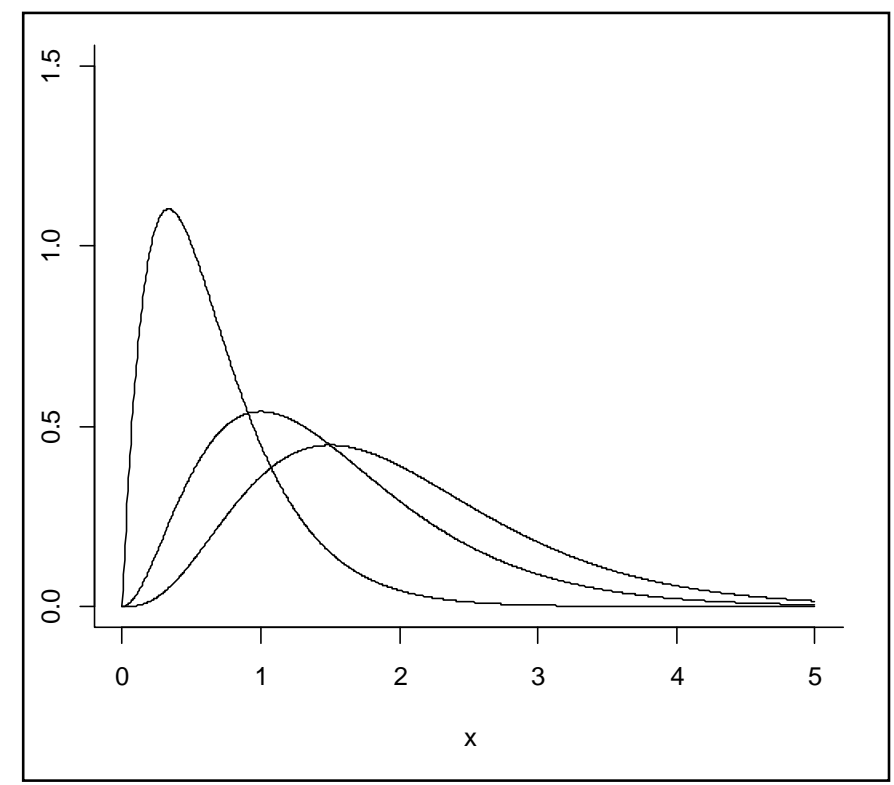

Figura 7: Curvas de distribuição gama. Representação esquemática de diferentes curvas de distribuição gama, assimétricas e com ponto de origem em $x=0$.

Como os valores de Ct, não possuem ponto de origem em zero $\left(x^{x=0}\right)$, nesse caso, a função densidade de probabilidade $f(x)$ de uma variável aleatória $X$ que segue uma distribuição gama foi acrescida de um parâmetro de locação $\lambda>0$ (Equação 9).

$$
f(x)=\frac{1}{\Gamma(k) \theta^{k}}(x+\lambda)^{k-1} \exp \left(-\frac{x+\lambda}{\theta}\right) I_{\left(\lambda_{2} \infty\right)}(x) .
$$


Equação 9: função densidade de probabilidade $f(x)$ de uma variável aleatória ${ }^{X}$ que segue uma distribuição gama. $k>0$ parâmetro de forma, $\theta>0$ parâmetro de escala e $I_{(A)}(x)$ função indicadora que assume $1 \mathrm{se}^{x}$ pertence ao conjunto ${ }^{A}$ e zero caso contrário. A média da variável ${ }^{X}$ é dada por $E(X)=\lambda+k \theta$ e a variância é dada por $\operatorname{Var}(X)=k \theta^{2}$.

Assim, para obtenção de um intervalo de referência para a variável (Equação 10) (Figura 8), foi utilizado o software de domínio público, denominado $\mathrm{R}$, disponível gratuitamente na página eletrônica http://www.r-project.org/ e os dados de Ct obtidos pelo processamento de 20 réplicas do CQI-NAT.

Equação 10: Descrição exemplificada das linhas de comando $R$ para a geração dos intervalos de limite superior e inferior do gráfico do CQI-NAT.

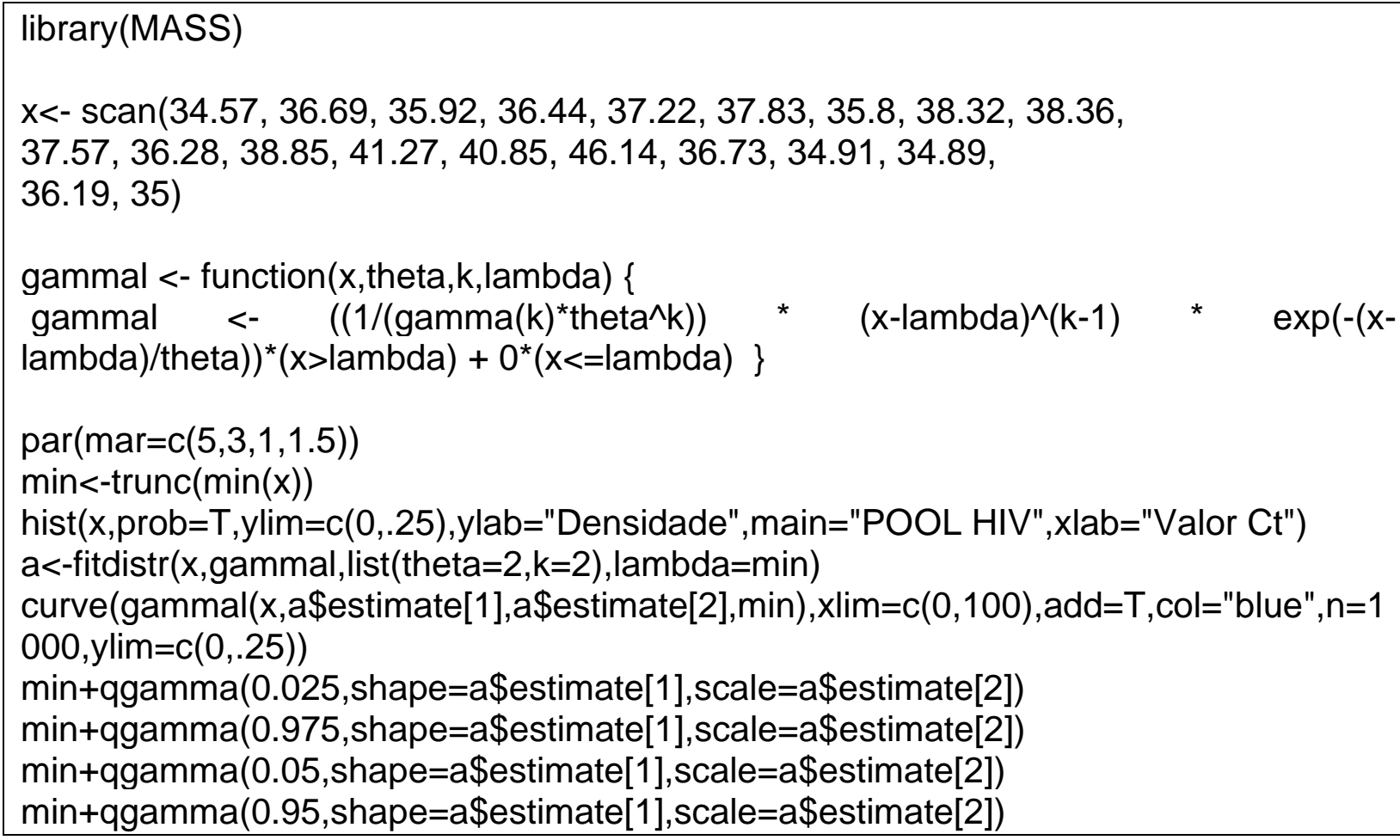

Equação 10: linhas de comando no software "R" referente a equação 9 para gerar o intervalo de referência do CQI-NAT com base em 20 réplicas deste. 


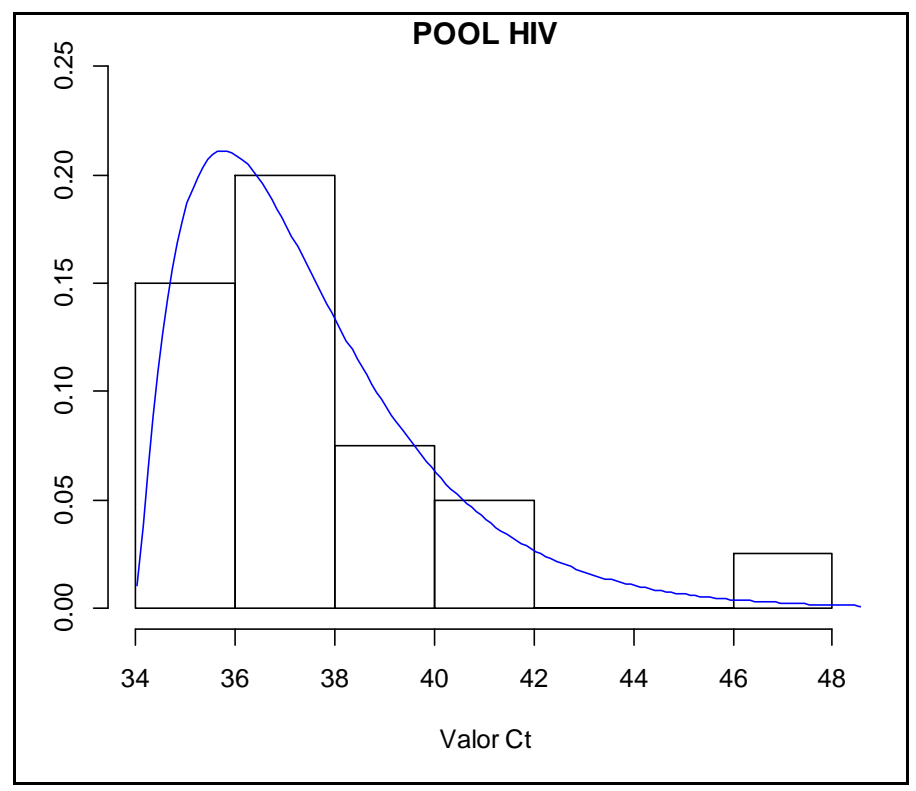

Figura 8: Curva de distribuição gama gerada a partir dos dados do Ct de 20 réplicas do CQI-NAT HIV processado em pool. O gráfico demonstra a curva azul referente à distribuição gama e histograma dos dados amostrais (Ct de CQI-NAT HIV). Análise realizada pelo software $R$.

A análise da distribuição dos dados de Ct (Figura 8) demonstra que a distribuição gama pode ser uma alternativa à curva normal para a geração dos intervalos de referência entre os limites superiores e inferiores do gráfico controle para acompanhamento do CQI-NAT na rotina.

Assim, são propostos que entre o intervalo de referência $(34,3298$ a 44,29222) para os valores $\mathrm{Ct}$, estejam contidos $95 \%$ da totalidade dos dados do CQI-NAT processado na rotina (Figura 9).

As figuras 10 e 11 representam exemplos da aplicabilidade da curva de distribuição gama para definição dos limites inferior e superior do gráfico controle para acompanhamento do CQI-NAT para HCV e HIV na rotina de testes do laboratório NAT do Hemocentro de Ribeirão Preto. 


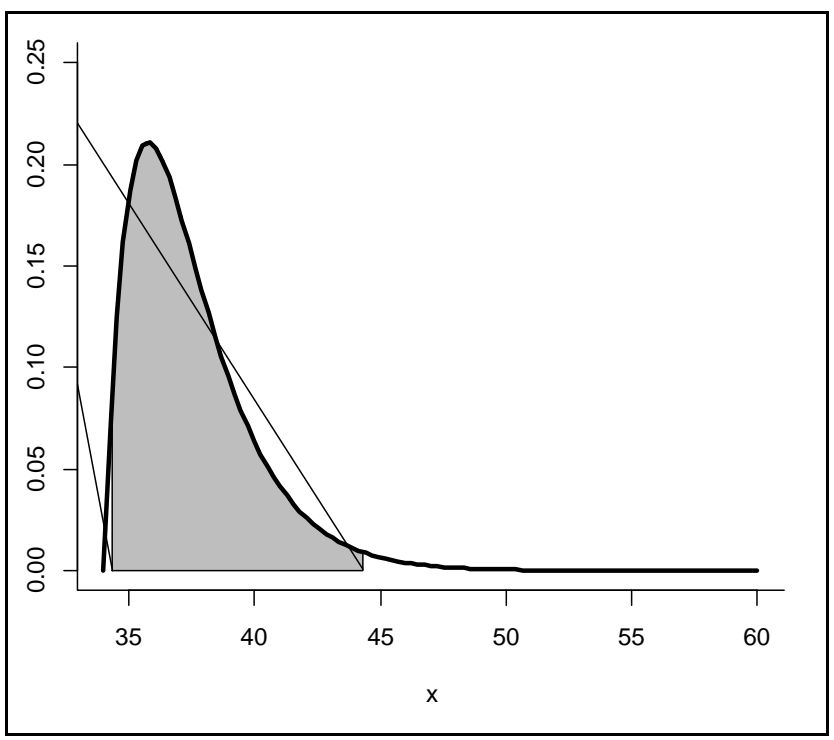

Figura 9: Curva de distribuição gama e intervalo de referência para os dados de $\mathrm{Ct}$ do CQI-NAT HIV. A região sombreada sob a curva contém o intervalo de 34,32 e 44,29 em que $95 \%$ da totalidade dos dados de Ct do CQI-NAT HIV podem estar contidos. 
CONTROLE DE QUALIDADE INTERNO

CQI-NAT HCV lote 001 - diluição 1:128

TESTE: HCV Bio-Manguinhos - Lote Kit 142NT007Z e $8 Z$ - Plataforma 1

Período: Abril/14

A)

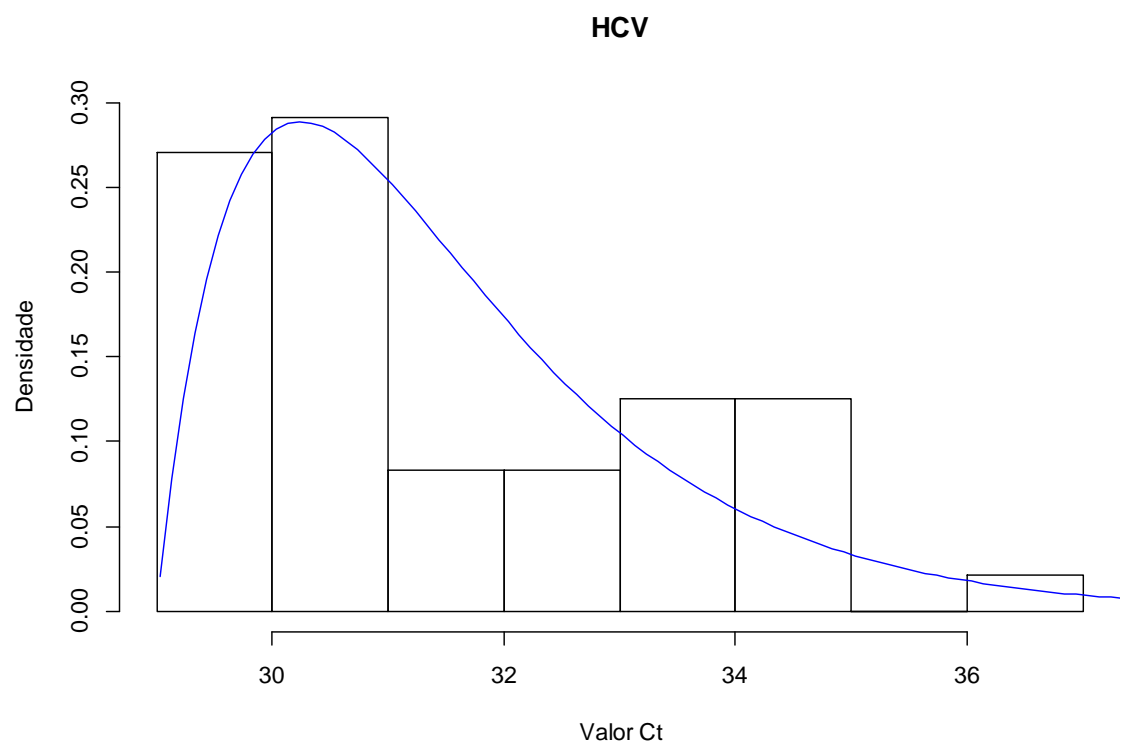

B) Estima-se que $95 \%$ dos dados populacionais pertencem ao intervalo de Ct de 29,$13 ; 37,39$.

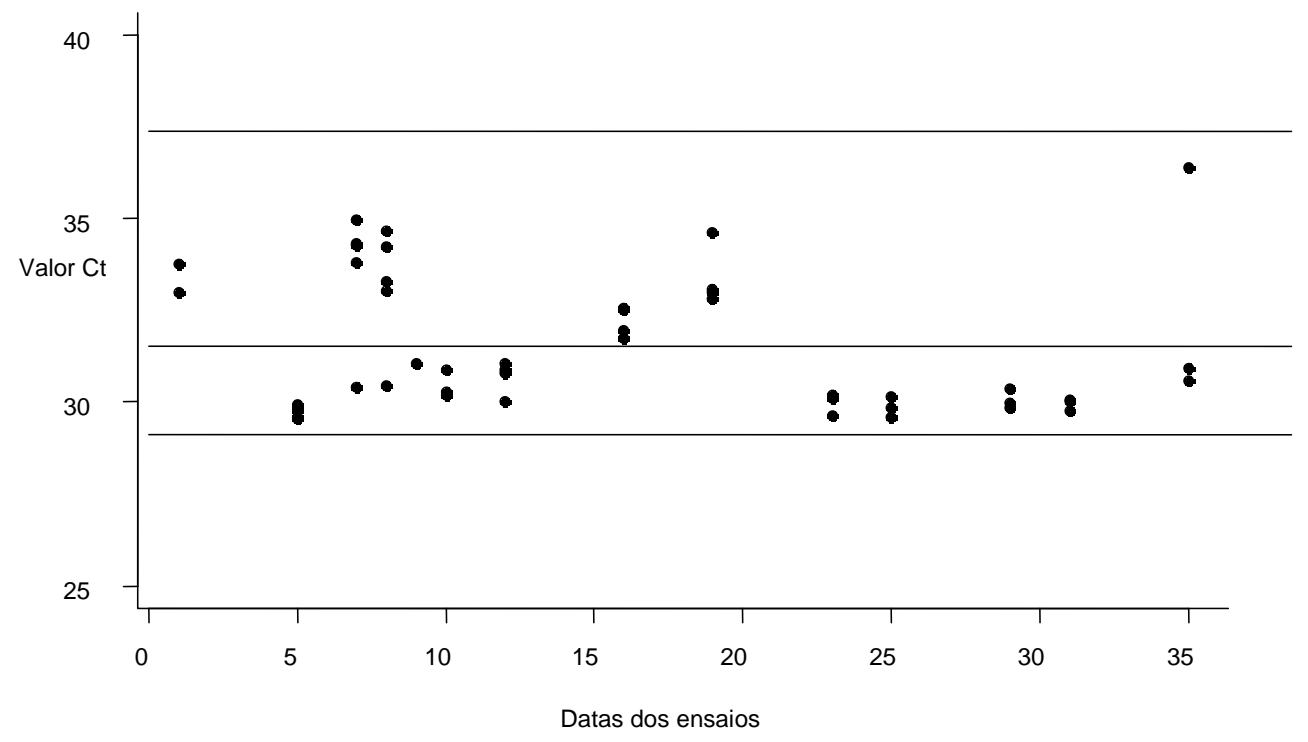

Figura 10: Aplicabilidade da curva de distribuição gama para definição dos limites inferior e superior do gráfico controle para acompanhamento do CQI-NAT HCV durante a rotina do mês de abril de 2014. A) Curva de distribuição gama e histograma contendo os resultados dos Ct. B) intervalo determinado pela curva gama foi utilizado para definição dos limites de aceitação do gráfico utilizado para acompanhamento dos resultados do CQI-NAT HCV, com as rotinas dispostas em triplicata. Para o mês de abril/2014, todas as rotinas de HCV encontraram-se dentro do intervalo de confiança de $95 \%$, não havendo rejeições devido à aplicação do CQI. 
CONTROLE DE QUALIDADE INTERNO

CQI-NAT HIV lote 001 - diluição 1:64

TESTE: HIV Bio-Manguinhos - Lote Kit 142NT007Z e $8 Z$ - Plataforma 1

Período: Abril/14

A)

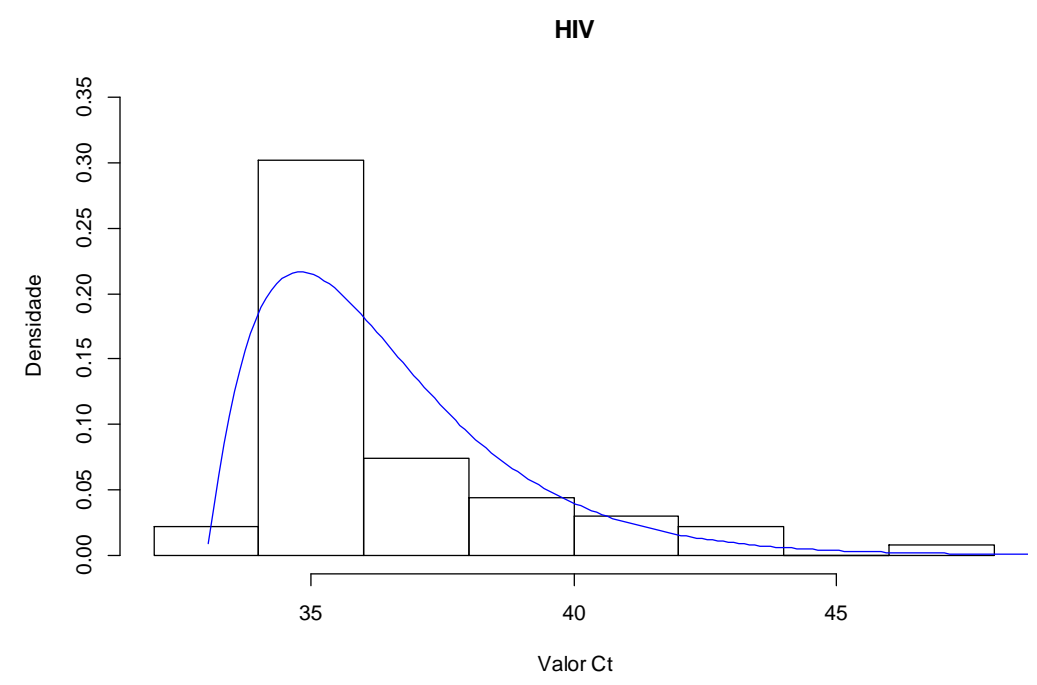

B) Estima-se que $95 \%$ dos dados populacionais pertencem ao intervalo de Ct de 33,$29 ; 43,30$.

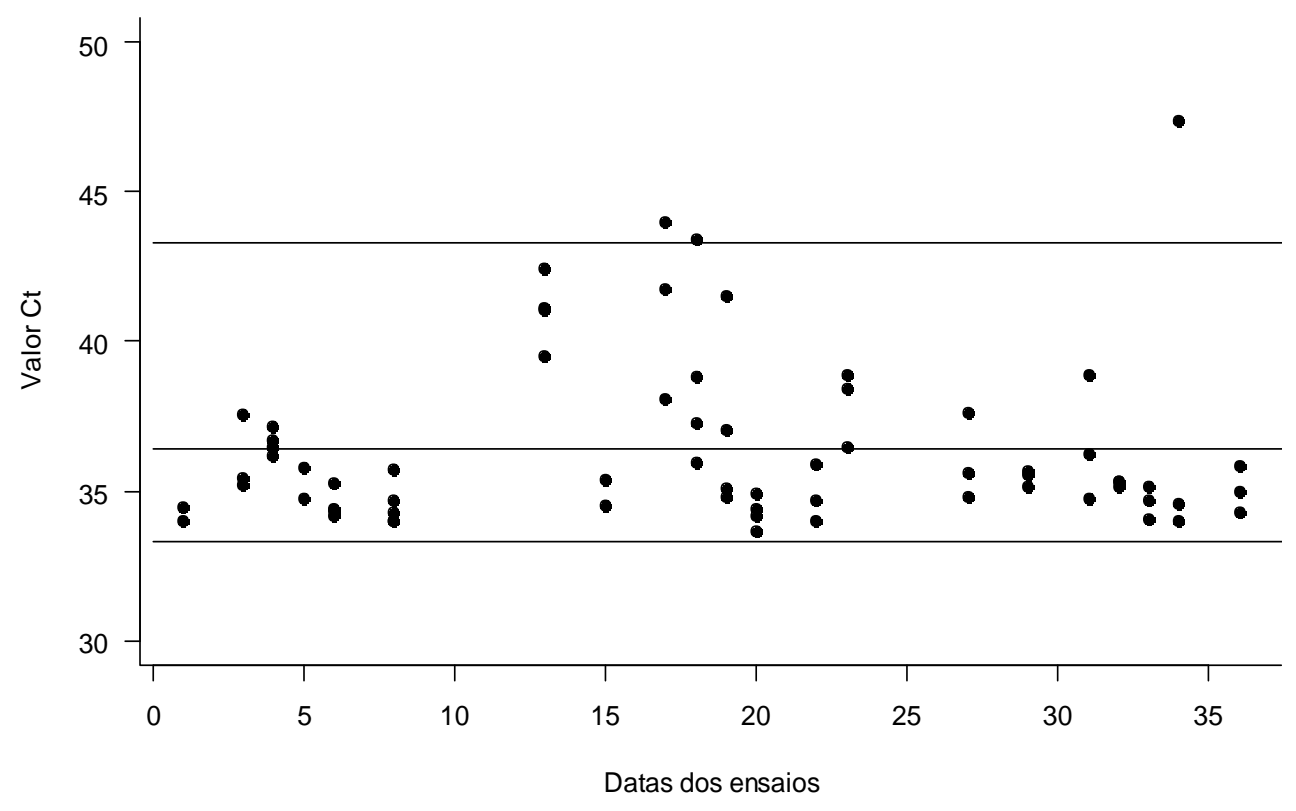

Figura 11: Aplicabilidade da curva de distribuição gama para definição dos limites inferior e superior do gráfico controle para acompanhamento do CQI-NAT HIV durante a rotina do mês de abril de 2014. A) curva de distribuição gama (em azul) e histograma contendo os resultados dos Ct. B) intervalo determinado pela curva gama foi utilizado para definição dos limites de aceitação do gráfico utilizado para acompanhamento dos resultados do CQI-NAT HIV, com as rotinas dispostas em triplicata. Para o mês de abril/2014, três rotinas de HIV encontraram-se fora do intervalo de confiança de $95 \%$, sendo portanto repetidas para liberação das amostras. 


\subsection{Processamento do CQI-NAT na rotina}

Na rotina NAT do Hemocentro de Ribeirão Preto, o CQI-NAT é processado preferencialmente em pool constituído de seis amostras, sendo o CQI-NAT HIV, o CQI-NAT HCV e quatro amostras de PHN. Caso a rotina seja realizada com amostras individuais, também os controles de qualidade são processados individualmente, porém sem a adição de PHN. Todos os critérios utilizados para confecção do CQINAT desde a seleção da amostra até a definição dos limites de aceitação estão descritos a seguir (Tabela 6 ).

Tabela 6: Resumo dos critérios utilizados no processo de produção e utilização do CQI-NAT na rotina do laboratório NAT do Hemocentro de Ribeirão Preto.

\begin{tabular}{ll}
\hline \multicolumn{1}{c}{ Etapa } & \multicolumn{1}{c}{ Critério proposto e utilizado* } \\
\hline & Bolsas de Plasma Fresco Congelado (PFC), \\
Seleção da bolsa positiva para produção do & $\begin{array}{l}\text { positivas unicamente para os vírus de interesse e, } \\
\text { negativas/não reagente para os demais } \\
\text { parâmetros sorológicos triados. }\end{array}$
\end{tabular}

Seleção da diluição ideal para uso na rotina NAT após avaliação da curva de diluição.

Homogeneidade e estabilidade.

Definição dos limites do gráfico controle para acompanhamento do CQI-NAT na rotina NAT.
Amostras com a maior diluição em houve a amplificação das duas replicas com valores de $\mathrm{Ct}$ homogêneos.

Variação de dois $\mathrm{Ct}$, acima ou abaixo, em relação à média dos Ct obtidos, e o coeficiente de variação inferior a $10 \%$.

Intervalo de referência proposto conforme curva de distribuição gama considerando os resultados de 20 réplicas do CQI-NAT.

\footnotetext{
${ }^{*}$ Relação dos critérios utilizados na confecção e utilização do CQI-NAT conforme todas as etapas do ciclo de produção, compreendendo desde a seleção da bolsa positiva, sua validação e posterior utilização na rotina NAT do Hemocentro de Ribeirão Preto.
}

Durante a realização da rotina NAT, o CQI-NAT foi processado em triplicata e os valores dos Ct para cada vírus, foram inseridos nos gráficos de dispersão (Figuras 10 e 11) para acompanhamento da conformidade. Para os resultados que apresentaram valor de $\mathrm{Ct}$ fora dos limites de aceitação, a rotina NAT foi repetida. 
CONCLUSÃO 


\section{CONCLUSÃO}

A obrigatoriedade da realização do NAT na triagem laboratorial, em 2013, como teste de rotina para detecção de doenças infecciosas transmissíveis por transfusão, em complemento com os testes de triagem sorológica, tem como objetivo a diminuição do risco residual de transmissão de doenças por transfusão.

Seguindo os princípios do sistema de gestão e controle de qualidade, os testes de biologia molecular devem acompanhar a cultura de validação e monitoramento dos processos dentro dos serviços de hemoterapia. Assim, a introdução do controle de qualidade interno como ferramenta para validação dos resultados obtidos nas rotinas NAT possibilita uma visão crítica da rotina e, contribui para identificação de possíveis não conformidades que podem interferir negativamente no padrão de qualidade final.

Com o objetivo de orientar os serviços de hemoterapia na implantação e utilização do controle de qualidade interno para o NAT, foram sugeridos neste manual, oito protocolos, validados com êxito na rotina do laboratório NAT do Hemocentro de Ribeirão Preto.

Os protocolos descrevem detalhadamente as etapas de seleção das bolsas positivas e realização de testes de validação até a produção das amostras de CQINAT, seu uso na rotina e a definição dos limites de aceitação conforme análises estatísticas, propondo assim, um novo modelo de avaliação dos dados das rotinas de testes.

Dessa forma, foi possível a utilização do CQI-NAT proposto neste trabalho pelo Hemocentro de Ribeirão Preto como uma ferramenta completa, acessível, padronizada, com registros de produção rastreáveis, de baixo custo operacional e que visa avaliar a reprodutibilidade dos testes e equipamentos utilizados na rotina, auxiliando na identificação de ações de melhoria contínua da qualidade no laboratório. 
APÊNDICES 
Apêndice I - Modelo de planilha de registro dos resultados da triagem laboratorial sorológica e molecular das bolsas selecionadas para produção do CQINAT e avaliação da reprodutibilidade da amostra.

\begin{tabular}{|c|c|c|c|c|c|c|c|c|}
\hline \multirow{2}{*}{$\begin{array}{c}\text { Identificação da } \\
\text { bolsa positiva de } \\
\text { Plasma Fresco } \\
\text { Congelado (PFC) }\end{array}$} & \multirow[t]{2}{*}{$\begin{array}{l}\text { Volume } \\
\qquad(\mathrm{mL})\end{array}$} & \multirow[t]{2}{*}{$\begin{array}{c}\text { Data da } \\
\text { coleta }\end{array}$} & \multicolumn{3}{|c|}{$\begin{array}{l}\text { Triagem sorológica (valor } \\
\text { de corte, ou cut off mais } \\
\text { elevado registrado no } \\
\text { teste sorológico) }\end{array}$} & \multicolumn{3}{|c|}{$\begin{array}{c}\text { Triagem molecular NAT } \\
\text { (valor de Cycle } \\
\text { threshold no NAT } \\
\text { individual da amostra) }\end{array}$} \\
\hline & & & HIV & $\mathrm{HCV}$ & HBC & HIV & $\mathrm{HCV}$ & $\mathrm{HBC}$ \\
\hline \multicolumn{9}{|c|}{ Avaliação da reprodutibilidade da amostra referente à bolsa positiva no } \\
\hline \multicolumn{3}{|c|}{ Réplica } & \multicolumn{2}{|c|}{ Ct vírus alvo } & \multicolumn{2}{|c|}{$\begin{array}{l}\text { Ct controle } \\
\text { interno }\end{array}$} & \multicolumn{2}{|c|}{$\begin{array}{l}\text { Ct controle } \\
\text { positivo }\end{array}$} \\
\hline \multicolumn{3}{|c|}{1} & & & & & & \\
\hline \multicolumn{3}{|c|}{2} & & & & & & \\
\hline \multicolumn{3}{|c|}{3} & & & & & & \\
\hline \multicolumn{3}{|c|}{4} & & & & & & \\
\hline \multicolumn{3}{|c|}{5} & & & & & & \\
\hline \multicolumn{3}{|c|}{6} & & & & & & \\
\hline \multicolumn{3}{|c|}{7} & & & & & & \\
\hline \multicolumn{3}{|c|}{8} & & & & & & \\
\hline
\end{tabular}


Apêndice II - Modelo de etiqueta de identificação para bolsa segregada com finalidade de produção do CQI-NAT.

PLASMA FRESCO CONGELADO PARA PRODUÇÃO DO CONTROLE DE QUALIDADE INTERNO NAT

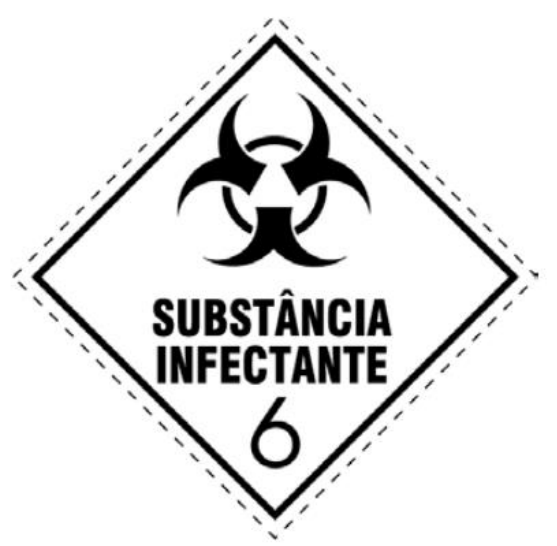

Fonte: ABNT NBR 7500:2013 
Apêndice III - Modelo de planilha para registro da temperatura de descongelamento das bolsas de PFC para produção do CQI-NAT.

\begin{tabular}{|c|c|c|c|}
\hline Identificação da bolsa & $\begin{array}{c}\text { Vírus para o qual } \\
\text { a bolsa é positiva }\end{array}$ & $\begin{array}{c}\text { Tempo (em horas) de } \\
\text { descongelamento }\end{array}$ & $\begin{array}{c}\text { Temperatura média } \\
\text { do banho-maria }\end{array}$ \\
\hline & & & \\
\hline & & & \\
\hline & & & \\
\hline
\end{tabular}


Apêndice IV - Modelo de planilha para registro de uso da luz ultravioleta.

\begin{tabular}{|l|l|l|l|}
\hline Data & Horário de início & Horário de término & Responsável \\
\hline & & & \\
\hline & & & \\
\hline & & & \\
\hline
\end{tabular}


Apêndice $\mathbf{V}$ - Modelo de etiqueta para identificação do tubo de aliquotagem da bolsa de plasma positiva.

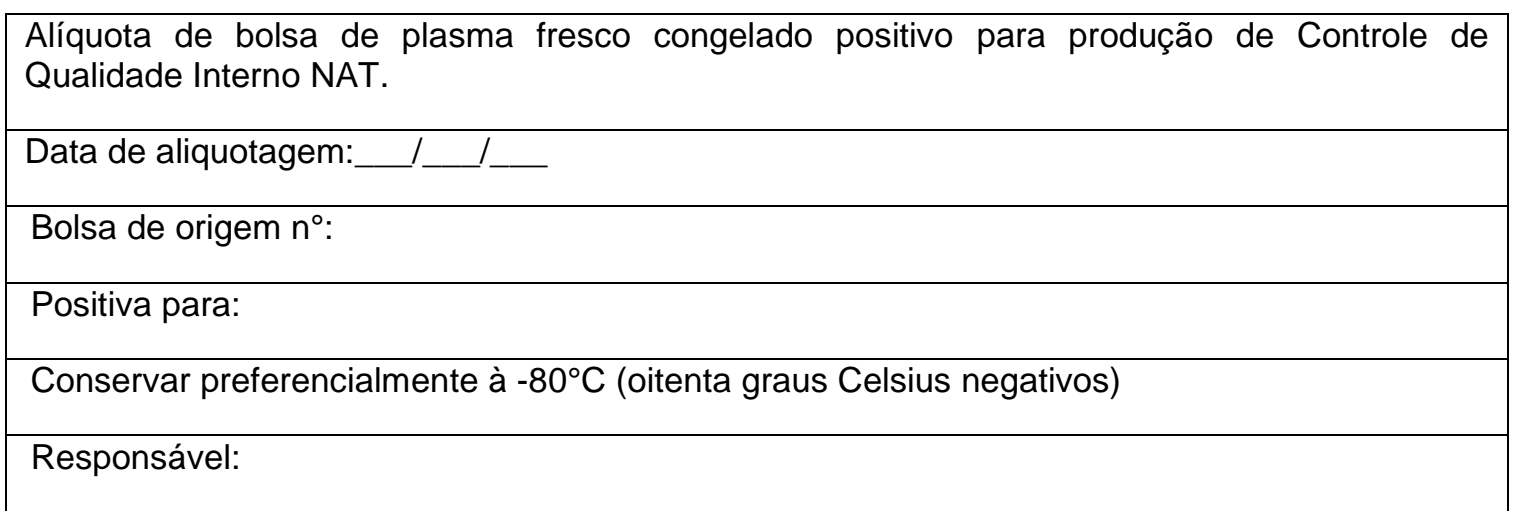


Apêndice VI - Modelo de planilha para registro da curva de diluição da amostra positiva.

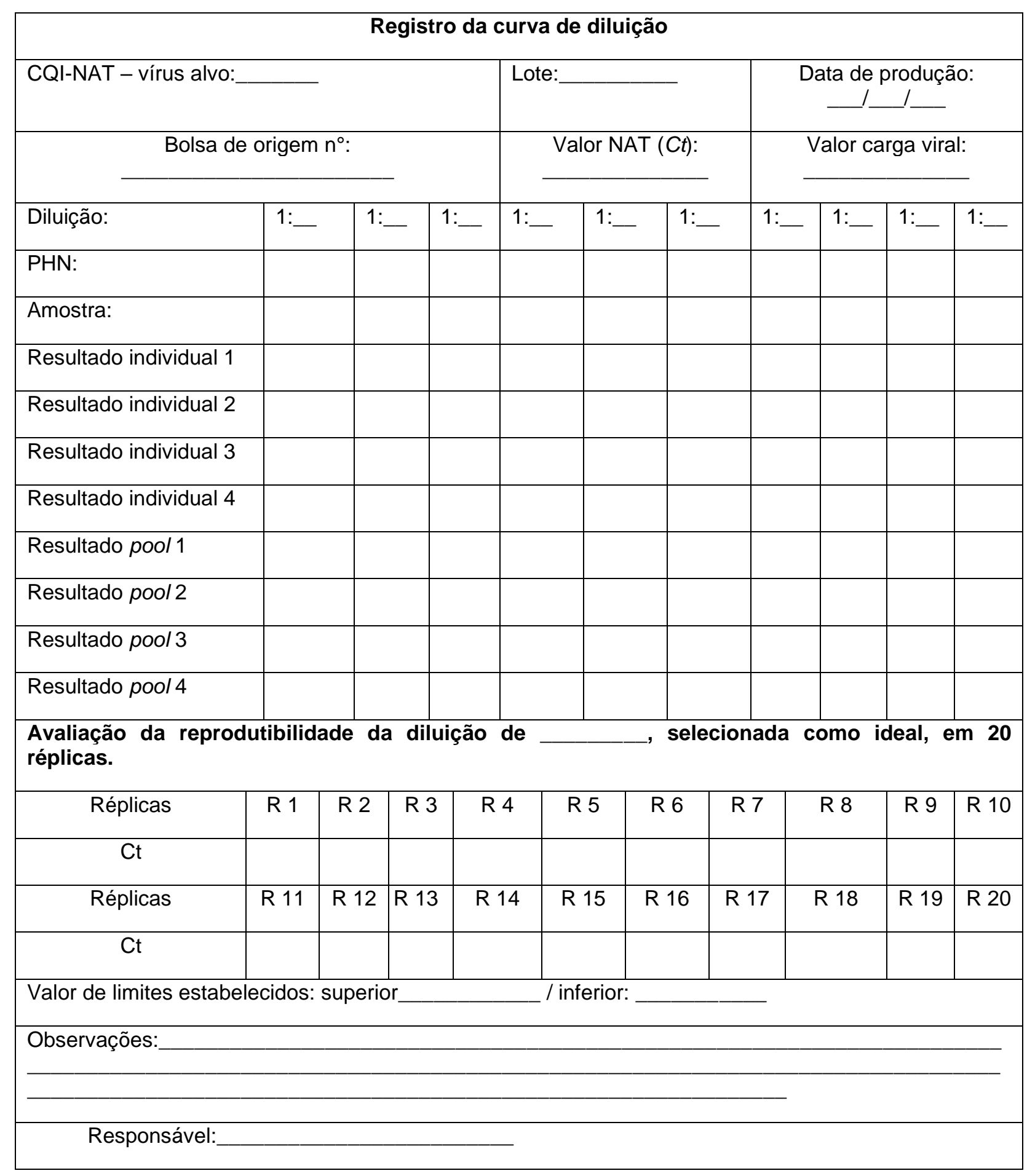


Apêndice VII - Modelo de registro da reprodutibilidade da diluição ideal da amostra positiva para CQI-NAT.

\begin{tabular}{|c|c|c|c|c|c|}
\hline \multicolumn{6}{|c|}{ Confirmação dos critérios da diluição da amostra positiva } \\
\hline \multicolumn{3}{|c|}{ Vírus alvo: } & \multicolumn{3}{|c|}{ Diluição ideal selecionada: $1:$} \\
\hline \multicolumn{3}{|c|}{ Processamento individual } & \multicolumn{3}{|c|}{ Processamento pool } \\
\hline Réplica & Valor amostra & Controle & Réplica & Valor amostra & Controle \\
\hline 1 & & & 1 & & \\
\hline 2 & & & 2 & & \\
\hline 3 & & & 3 & & \\
\hline 4 & & & 4 & & \\
\hline 5 & & & 5 & & \\
\hline 6 & & & 6 & & \\
\hline 7 & & & 7 & & \\
\hline 8 & & & 8 & & \\
\hline 9 & & & 9 & & \\
\hline 10 & & & & & \\
\hline & & & & & \\
\hline 11 & & & 11 & & \\
\hline 12 & & & 12 & & \\
\hline 13 & & & 13 & & \\
\hline 14 & & & 14 & & \\
\hline 15 & & & 15 & & \\
\hline 16 & & & 16 & & \\
\hline 17 & & & 17 & & \\
\hline 18 & & & 18 & & \\
\hline 19 & & & 19 & & \\
\hline & & & 19 & & \\
\hline 20 & & & 20 & & \\
\hline Média & & & Média & & \\
\hline${ }^{\star} \mathrm{DP}$ & & & ${ }^{\star} \mathrm{DP}$ & & \\
\hline${ }^{\star *} \mathrm{CV}$ & & & ${ }^{\star \star} \mathrm{CV}$ & & \\
\hline
\end{tabular}

${ }^{*}$ DP: desvio padrão; ${ }^{*} \mathrm{CV}$ : coeficiente de variação. 
Apêndice VIII - Modelo de etiqueta para identificação do CQI-NAT.

\begin{tabular}{|l|l|}
\hline \multicolumn{2}{|l|}{ Controle de Qualidade Interno NAT. } \\
\hline Data de aliquotagem: & Vírus alvo: \\
\hline Diluição selecionada: $1:$ & Valor do Ct ou carga viral: \\
\hline Bolsa de origem $\mathrm{n}^{\circ}:$ & Valores limites: \\
\hline Número sequencial da amostra de CQI-NAT: \\
\hline Conservar preferencialmente à $-80^{\circ} \mathrm{C}$ (oitenta graus Celsius negativos). \\
Utilizar em até duas rotinas e descartar posteriormente. \\
\hline Responsável:
\end{tabular}


Apêndice IX - Exemplo para seleção de amostras aleatórias utilizando a função do programa Excel.

\begin{tabular}{|c|c|c|}
\hline A & B & C \\
\hline Primeira alíquota & 1 & =ALEATÓRIOENTRE(B1;B2) \\
\hline Última alíquota & 30 & \\
\hline
\end{tabular}


Apêndice X - Modelo de registro dos dados do teste de homogeneidade do CQINAT.

\begin{tabular}{|c|c|c|}
\hline \multicolumn{3}{|c|}{ Teste de Homogeneidade } \\
\hline \multicolumn{3}{|c|}{ Vírus alvo: } \\
\hline \multicolumn{3}{|c|}{ Data: ___ I I } \\
\hline \multicolumn{3}{|c|}{ Responsável: } \\
\hline *Seq. & $\begin{array}{l}\text { Amostra CQI-NAT (numeração sequencial } \\
\text { da amostra selecionada aleatoriamente) }\end{array}$ & Resultado NAT \\
\hline 1 & Exemplo: 04 & \\
\hline 2 & & \\
\hline 3 & & \\
\hline 4 & & \\
\hline 5 & & \\
\hline 6 & & \\
\hline 7 & & \\
\hline 8 & & \\
\hline 9 & & \\
\hline 10 & & \\
\hline Média & & \\
\hline${ }^{* *} \mathrm{DP}$ & & \\
\hline${ }^{* * *} \mathrm{CV}$ & & \\
\hline
\end{tabular}

${ }^{\star}$ Seq. - numeração sequencial; ${ }^{* *} \mathrm{DP}$ : desvio padrão; ${ }^{* * *} \mathrm{CV}$ : coeficiente de variação. 
Apêndice XI - Modelo de registro dos dados do teste de estabilidade.

\begin{tabular}{|c|c|c|c|}
\hline \multicolumn{4}{|c|}{ Teste de Estabilidade } \\
\hline \multicolumn{4}{|l|}{ Vírus alvo: } \\
\hline \multicolumn{4}{|l|}{ Responsável: } \\
\hline Temperatura & $\begin{array}{l}\text { Amostra CQI- } \\
\text { NAT } \\
\text { (numeração } \\
\text { sequencial da } \\
\text { amostra } \\
\text { selecionada } \\
\text { aleatoriamente) }\end{array}$ & $\begin{array}{c}\text { Data do } \\
\text { teste }\end{array}$ & $\begin{array}{c}\text { Resultado } \\
\text { NAT } \\
\text { (Ct) }\end{array}$ \\
\hline \multirow{2}{*}{$\begin{array}{c}1 \\
\left(-80^{\circ} \mathrm{C}\right)\end{array}$} & Exemplo: 14 & & \\
\hline & & & \\
\hline \multicolumn{4}{|l|}{ Média } \\
\hline \multicolumn{4}{|l|}{${ }^{\star \star} \mathrm{DP}$} \\
\hline${ }^{* * *} \mathrm{CV}$ & & & \\
\hline
\end{tabular}

${ }^{* \star} \mathrm{DP}$ : desvio padrão; ${ }^{* \star} \mathrm{CV}$ : coeficiente de variação. 
Apêndice XII - Modelo de planilha para registro da produção de PHN.

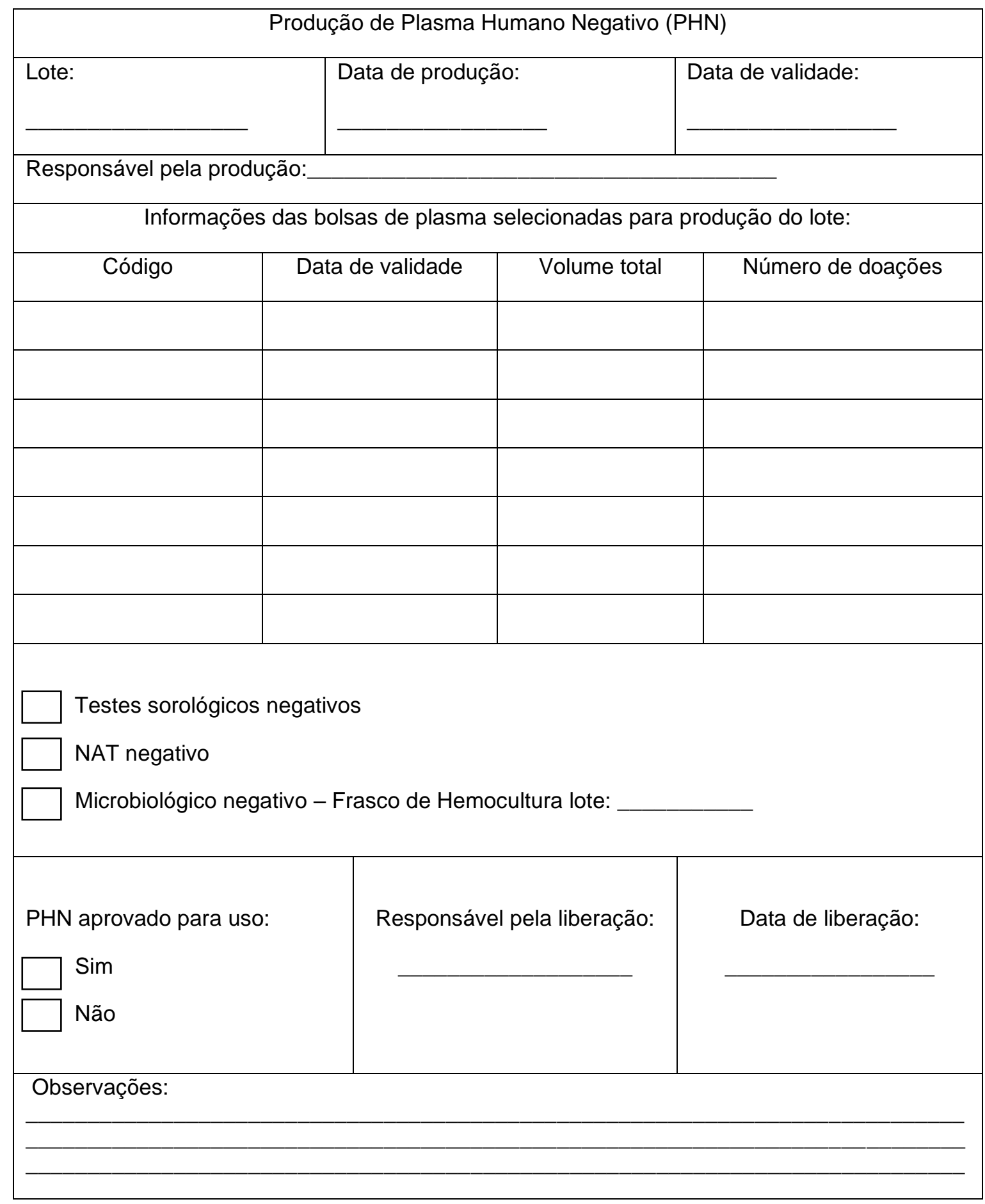


Apêndice XIII - Modelo de etiqueta para identificação dos tubos do lote de PHN.

\begin{tabular}{|l|l|}
\hline \multicolumn{2}{|c|}{ Plasma Humano Negativo (PHN) } \\
\hline Lote: & Responsável: \\
\hline Data de preparo: & Data de validade: \\
& (seis meses após preparo) \\
\hline Armazenar a temperatura de 20ํ negativos ou abaixo. \\
\hline $\begin{array}{l}\text { Descrição: Plasma negativo utilizado como diluente para produção do Controle de Qualidade } \\
\text { Interno do Teste do ácido Nucleico - CQI-NAT }\end{array}$ \\
\hline
\end{tabular}


Apêndice XIV - Modelo de tabela contendo dados relevantes para acompanhamento do CQI-NAT na rotina de testes e para construção do gráfico de dispersão.

\begin{tabular}{|l|l|l|l|l|}
\hline Data da rotina & Ct HIV & Ct HCV & $\begin{array}{c}\text { Ct controle } \\
\text { interno }\end{array}$ & $\begin{array}{c}\text { Teste (pool ou } \\
\text { individual) }\end{array}$ \\
\hline & & & & \\
\hline
\end{tabular}




\section{REFERÊNCIAS BIBLIOGRÁFICAS}

AABB. Technical Manual. Infectious Disease Screening. 17ª edição 2011.

ABNT. ABNT NBR ISO/IEC 17025:2006 - Requisitos gerais para a competência de laboratórios de ensaio e calibração 2006.

ABNT NBR ISO
Requisitos: 28 p. 2008 .

Sistemas de gestão da qualidade - Requisitos: 28 p. 2008b.

. ABNT NBR ISO/IEC 17043:2011 - Avaliação de conformidade - requisitos gerais para ensaios de proficiência 2011.

ANVISA Banco de dados disponível para consulta de produtos aprovados para comercialização no Brasil. Disponivel em $<$ http://www.anvisa.gov.br/datavisa/consulta_produto_correlato/rconsulta_produto_det alhe.asp.>.

BEER, N. et al. Accuracy of hepatitis $C$ virus core antigen testing in pools among seroconverters. Transfusion, v. 46, n. 10, p. 1822-8, Oct 2006.

BIO-MANGUINHOS/FIOCRUZ. Manual de Treinamento NAT 2011.

BRASIL. Portaria GM/MS 1.840/1996. SAÚDE, M. D. 1996.

Programa da qualidade do sangue (PQS) - instrumento de autoavaliação dos órgãos executores das atividades hemoterápicas. SAÚDE, M. D. Brasília 1999.

Portaria 1.407/2002. SAÚDE, M. D. 2002a.

. Portaria GM 262/2002. SAÚDE, M. D. 2002b.

. Portaria 79/2003. SAÚDE, M. D. 2003.

Portaria 112/2004. SAÚDE, M. D. 2004.

A, B, C, D, E de hepatites para comunicadores / Ministério da Saúde. MINISTÉRIO DA SAÚDE, S. D. V. E. S., DEPARTAMENTO DE VIGILÂNCIA EPIDEMIOLÓGICA. Brasília: Ministério da Saúde. Série F. Comunicação e Educação em Saúde 2005.

Boletim Epidemiológico - Hepatites virais. MINISTÉRIO DA SAÚDE SECRETARIA DE VIGILÂNCIA EM SAÚDE - DEPARTAMENTO DE DST, A. E. H. V. Brasília: Ministério da Saúde. Ano III - no 1: 19 p. 2012. 
Boletim Epidemiológico - AIDS e DST. MINISTÉRIO DA SAÚDE SECRETARIA DE VIGILÂNCIA EM SAÚDE - DEPARTAMENTO DE DST, A. E. H. V. Brasília: Ministério da Saúde: 32 p. 2013a.

Portaria 2.712/2013. SAÚDE, M. D. 2013b.

Portaria 25/2013. SUS/MS, C. N. D. I. D. T. N. 2013c.

RDC 51/2013. SANITÁRIA/MS, A. N. D. V. 2013d.

Caderno de informação: sangue e hemoderivados. MINISTÉRIO DA SAÚDE, S. D. A. À. S., DEPARTAMENTO DE ATENÇÃO HOSPITALAR E DE URGÊNCIA. Brasil: Ministério da Saúde 2014a.

. Portaria Conjunta SAS/SE 193/2014. SAÚDE, M. D. 2014b.

Portaria Conjunta SAS/SE 239/2014. SAÚDE, M. D. 2014c.

Relatório de Hemovigilância dados consolidados 2007 - 2013 - Agência Nacional de Vigilância Sanitária. AGÊNCIA NACIONAL DE VIGILÂNCIA SANITÁRIA. Brasil: Ministério da Saúde 2014d.

BLUMBERG, B. S.; ALTEN H. J.; VISNICH S. A "New" Antigen in Leukemia Sera. JAMA, 1965.

Family studies of a Human Serum Isoantigen System (Australia Antigen). Am J Human Genet 18: 594, 1966.

BUSCH, M. P. et al. A new strategy for estimating risks of transfusion-transmitted viral infections based on rates of detection of recently infected donors. Transfusion, v. 45, n. 2, p. 254-64, Feb 2005.

. Committee report. Nucleic acid amplification testing of blood donors for transfusion-transmitted infectious diseases: Report of the Interorganizational Task Force on Nucleic Acid Amplification Testing of Blood Donors. Transfusion, v. 40, n. 2, p. 143-59, Feb 2000.

. Time course of detection of viral and serologic markers preceding human immunodeficiency virus type 1 seroconversion: implications for screening of blood and tissue donors. Transfusion, v. 35, n. 2, p. 91-7, Feb 1995.

CARDOSO, M. S.; KOERNER, K.; KUBANEK, B. Mini-pool screening by nucleic acid testing for hepatitis B virus, hepatitis C virus, and HIV: preliminary results. Transfusion, v. 38, n. 10, p. 905-7, Oct 1998.

CHOI, S. C.; WETTE, R. Maximum likelihood estimation of the parameters of the gamma distribution and their bias. Technometrics, 1969. 683-690. 
CORNETT, J. K.; KIRN, T. J. Laboratory diagnosis of HIV in adults: a review of current methods. Clin Infect Dis, v. 57, n. 5, p. 712-8, Sep 2013.

COSTE, J. et al. Implementation of donor screening for infectious agents transmitted by blood by nucleic acid technology: update to 2003. Vox Sang, v. 88, n. 4, p. 289303, May 2005.

Dane, D.S.; Cameron C.H.; Briggs M. Virus-like particles in serum of patients with Australia antigen-associated hepatitis. Lancet, I: 695, 1970.

DASKALAKIS, D. HIV diagnostic testing: evolving technology and testing strategies. Top Antivir Med, v. 19, n. 1, p. 18-22, Feb-Mar 2011.

DEMING, W. E. Qualidade: A Revolução da Administração. Rio de Janeiro: 1990.

DODD, R. Y.; NOTARI, E. P. T.; STRAMER, S. L. Current prevalence and incidence of infectious disease markers and estimated window-period risk in the American Red Cross blood donor population. Transfusion, v. 42, n. 8, p. 975-9, Aug 2002.

DONABEDIAN, A. A gestão da qualidade total na perspectiva dos serviços de saúde. Rio de Janeiro: Tradução de Roberto Passos Nogueira, 1994.

DONAHUE, J. G. et al. The declining risk of post-transfusion hepatitis $\mathrm{C}$ virus infection. N Engl J Med, v. 327, n. 6, p. 369-73, Aug 1992. Disponível em:<http://www.ncbi.nlm.nih.gov/pubmed/1320736 >

DWYRE, D. M.; FERNANDO, L. P.; HOLLAND, P. V. Hepatitis B, hepatitis C and HIV transfusion-transmitted infections in the 21st century. Vox Sang, v. 100, n. 1, p. 92-8, Jan 2011.

FIEBIG, E. W. et al. Dynamics of HIV viremia and antibody seroconversion in plasma donors: implications for diagnosis and staging of primary HIV infection. Aids, v. 17, n. 13, p. 1871-9, Sep 52003.

GELDERBLOM, H. R.; OZEL, M.; PAULI, G. Morphogenesis and morphology of HIV. Structure-function relations. Arch Virol, v. 106, n. 1-2, p. 1-13, 1989. Disponível em: < http://www.ncbi.nlm.nih.gov/pubmed/2669684 >.

GEN-PROBE. Gen-Probe Incorporated®, Procleix Ultrio Assay® HIV/HBV/HCV. San Diego, CA. Rev. A 2011.

GOTO, T.; NAKAI, M.; IKUTA, K. The life-cycle of human immunodeficiency virus type 1. Micron, v. 29, n. 2-3, p. 123-38, Apr-Jun 1998.

GRANT, P. R.; BUSCH, M. P. Nucleic acid amplification technology methods used in blood donor screening. Transfus Med, v. 12, n. 4, p. 229-42, Aug 2002. 
ISO:9000, A. N. ABNT NBR ISO 9000:2005 Sistemas de gestão da qualidade Fundamentos e vocabulário: 1-35 p. 2005.

JACKSON, B. R. et al. The cost-effectiveness of NAT for HIV, HCV, and HBV in whole-blood donations. Transfusion, v. 43, n. 6, p. 721-9, Jun 2003.

JUNQUEIRA, P. C.; ROSENBLIT, J.; HAMERSCHLAK, N. História da Hemoterapia no Brasil. Revista Brasileira de Hematologia e Hemoterapia, v. v. 27, n. São José do Rio Preto, 2005.

KLEINMAN, S. H.; LELIE, N.; BUSCH, M. P. Infectivity of human immunodeficiency virus-1, hepatitis $C$ virus, and hepatitis $B$ virus and risk of transmission by transfusion. In: (Ed.). Transfusion. United States, v.49, 2009. p.2454-89.

KOSAN, E. et al. Can the nucleic acid amplification test (NAT) be an alternative to the serologic tests? A prospective study, the results of 18,200 blood donors from the Turkish Red Crescent. Transfus Apher Sci, v. 43, n. 3, p. 269-72, Dec 2010.

LAPERCHE, S. et al. Transfusion safety on the African continent: an international quality control of virus testing in blood banks. In: (Ed.). Transfusion. United States, v.49, 2009. p.1600-8.

LIANG, T. J. Hepatitis B: the virus and disease. Hepatology, v. 49, n. 5 Suppl, p. S1321, May 2009.

MAINZ, J. Defining and classifying clinical indicators for quality improvement. Int $\mathbf{J}$ Qual Health Care, v. 15, n. 6, p. 523-30, Dec 2003.

MALIK, A. M.; SCHIESARI, L. M. C. Qualidade na gestão local de serviços e ações de saúde. São Paulo: Faculdade de Saúde Pública da Universidade de São Paulo, 1998. 241.

MULLIS, K. et al. Specific enzymatic amplification of DNA in vitro: the polymerase chain reaction. Cold Spring Harb Symp Quant Biol, v. 51 Pt 1, p. 263-73, 1986.

OLIVEIRA, C. A.; MENDES, M. E. Gestão da fase analítica do laboratório: como assegurar a qualidade na prática. Rio de Janeiro: Control Lab, 2011.

OWEN, S. M. Testing for acute HIV infection: implications for treatment as prevention. Curr Opin HIV AIDS, v. 7, n. 2, p. 125-30, Mar 2012.

PETRY, A. Implantação dos Testes de Amplificação de Ácidos Nucleico HIV/HCV Bio-Manguinhos na triagem de doadores de sangue: questões epidemiológicas e logísticas. 2013. 152 (Tese (doutorado)). Centro de ciências da saúde, Universidade Federal de Santa Catarina, Florianópolis, SC.

ROCHE. Cobas S201 TaqScreen MPX® HIV/HBV/HCV - Roche Molecular

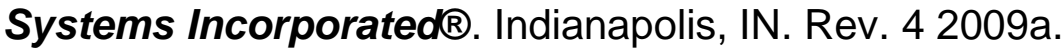



Incorporated $2009 \mathrm{~b}$.

ROTH, W. K.; WEBER, M.; SEIFRIED, E. Feasibility and efficacy of routine PCR screening of blood donations for hepatitis $C$ virus, hepatitis $B$ virus, and HIV-1 in a blood-bank setting. In: (Ed.). Lancet. England, v.353, 1999. p.359-63.

SABINO, E. C. et al. Estimated risk of transfusion-transmitted HIV infection in Sao Paulo, Brazil. Transfusion, v. 39, n. 10, p. 1152-3, Oct 1999.

SAKUMA, A.; OTTOBONI, M. Â. P.; SIERRA, P. C. Manual para controle da qualidade do sangue total e hemocomponentes. São Paulo: RedSang SIBRATEC, 2011. 120.

SCHREIBER, G. B. The Risk of Transfusion-Transmitted Viral Infections. BUSCH, M. P.;KLEINMAN, S. H., et al: The New England Journal of Medicine. 334: 1685 1690 p. 1996.

SIMMONDS, P. Genetic diversity and evolution of hepatitis C virus--15 years on. J Gen Virol, v. 85, n. Pt 11, p. 3173-88, Nov 2004. Disponível em: < http://www.ncbi.nlm.nih.gov/pubmed/15483230 >.

SIMMONDS, $P$. et al. Classification of hepatitis $C$ virus into six major genotypes and a series of subtypes by phylogenetic analysis of the NS-5 region. J Gen Virol, v. 74 ( Pt 11), p. 2391-9, Nov 1993. Disponível em: < http://www.ncbi.nlm.nih.gov/pubmed/8245854 >.

STRAMER, S. L. et al. Detection of HIV-1 and HCV infections among antibodynegative blood donors by nucleic acid-amplification testing. In: (Ed.). N Engl J Med. United States: 2004 Massachusetts Medical Society, v.351, 2004. p.760-8.

THOMPSON, M.; WOOD, R. IUPAC (INTERNATIONAL UNION OF PURE AND APPLIED CHEMISTRY): HARMONIZED GUIDELINES FOR INTERNAL QUALITY CONTROL IN ANALYTICAL CHEMISTRY LABORATORIES Pure \& Appl. Chem. VOLUME 67: 649-666 p. 1995.

TUKE, P. W. et al. Hepatitis C virus window-phase infections: closing the window on hepatitis C virus. Transfusion, v. 48, n. 4, p. 594-600, Apr 2008.

TURNER, B. G.; SUMMERS, M. F. Structural biology of HIV. J Mol Biol, v. 285, n. 1, p. 1-32, Jan 81999.

TÉCNICAS, A.-A. B. D. N. Sistemas de gestão da qualidade - Requisitos: 28 p. 2008.

VALENTINE-THON, E. Quality control in nucleic acid testing--where do we stand? In: (Ed.). J Clin Virol. Netherlands, v.25 Suppl 3, 2002. p.S13-21. 
VAN DER VOET, H.; VAN RHIJN, J. A.; VAN DE WIEL, H. J. Inter-laboratory, time, and fitness-for-purpose aspects of effective validation. Analytica Chimica Acta, v. 391, n. 2, p. 159-171, 5/31/ 1999. Disponível em: < http://www.sciencedirect.com/science/article/pii/S0003267099001099 >.

WESTGARD, J. O. et al. A multi-rule Shewhart chart for quality control in clinical chemistry. Clin Chem, v. 27, n. 3, p. 493-501, Mar 1981.

WILLKOMMEN, H.; SCHMIDT, I.; LOWER, J. Safety issues for plasma derivatives and benefit from NAT testing. Biologicals, v. 27, n. 4, p. 325-31, Dec 1999. 